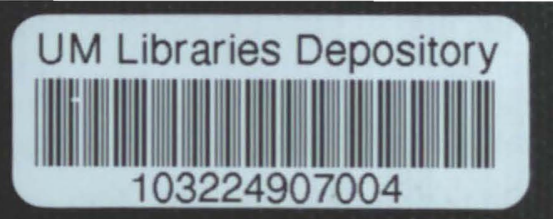




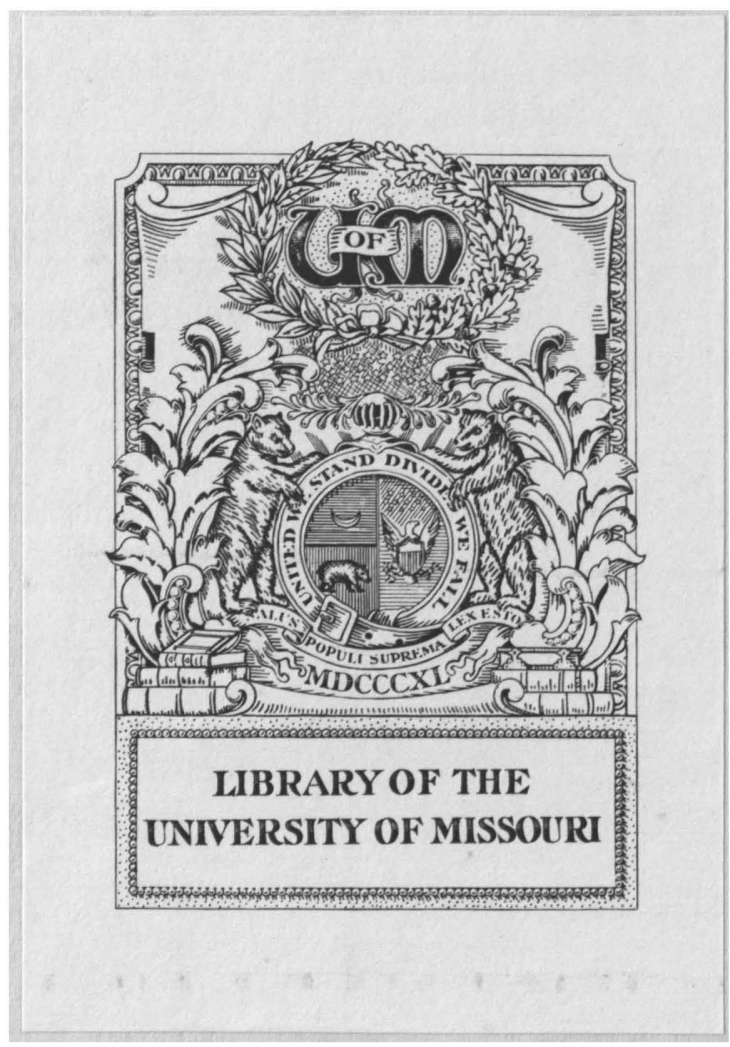






A STUDY OF THE PHENOMENON OF BARRENNESS IN CORN.

30

A THESIS SUBMITTED

BY

FRANK HOWARD

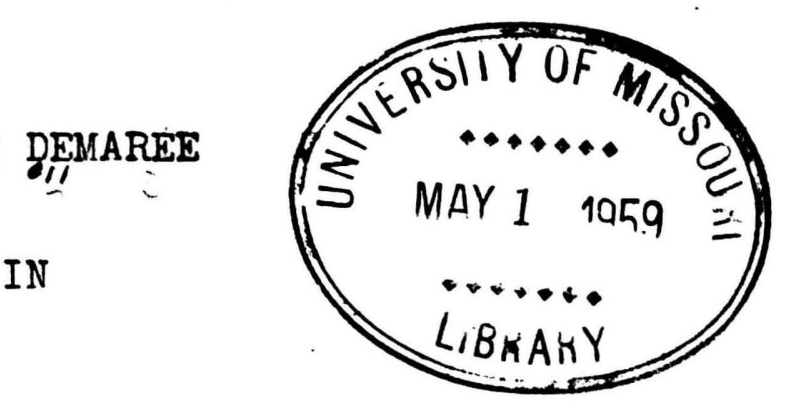

PARTIAL FULFILLMENT OF THE

REQUIREMENTS FOR THE DEGREE OF

MASTER OF SCIFNCE IN AGRICULTURE.

UNIVERSITY OF MISSOURI.

$$
\text { JUNE--1911. }
$$



CONTENTS.

Foreword-_- 1

Object of Experiment-_...--

Plan of Experiment-_-_ 3

Work in 1909-_ 5

Discussion Results 1909-_. 10

Barrenness due to Soil and Stand-_... 16

Work in 1910

Hereditary Barrennese -...

Effect of Inbreeding on Barrenness-_... 36

Description of Barren StalkB_... 39

Analysis of Barren Stalks-_-_

Barrenness in Corn Varieties-_... 51

Barrenness in Breeding Corn-_... 56

Contemporary Data-_-_-_

Conclusione-_- 63

Bibliography-_.

Phot.ographs-_- 

FOREWORD.

Barrenness in corn is one of the most commonly observed phenomena exhibited by this prominent cereal, and one of the least understood. Why various, seemingly growthy and hardy stalks of corn fail to produce grain has been a source of wonder and comment to both practical farmers and agricultural investigators as well.

Strange as it may seem, however, there has been practicelly no work done to discover why the maize plant, or any other grain normally bisexuel, should be sterile. Many theories have been advanced to explain the phenomenon such as lack of food, lack of constitutional vigor, thickness of planting, and inbreeding. It has also been suggested that the condition. might be hereditary, but this has in the main been generally rejected as unsound, thinking that since a barren stalk produces no seed 1t must surely breed itself out. Whether or not any or all of these theories will stand the test of accurate experimentation remains to be seen. On the other hand it is an undoubted fact that the barren tendency still persists in all sub-species and varieties of corn. Farmers realize their detrimental effect and are continually asking for a method whereby they may be eliminated from their fields.

Nearly all attempts to eliminate them haje failed so far becruse it is very hard to say a stalk will be barren at tasseling time and once past that time the damage is done and ony interference is more than useless. 

Seeing then that the subject has an economic bearing as well as a purely scientific interest, what are the factors that influence barrenness in corn?

\section{OBJECT OF THE EXPERINENT.}

The object of this work was to make a study of barren stalks of corn to discover the causes of barrenness, if possible, and to find out the factors which influence barrenness in any way. There seems to be some difference in the barren quality of stalks which are naturally barren and those which are berren due to environmental conditions. The causes of permenent barrenness would then refer to the first condition and the factors influencing induced barrenness to the latter condition.

Once in a while a perfectly barren stalk will be found in the field of corn where no possible explanation can be given outside of the question of heredity, as to why this stalk should not have borne an ear. Mll conditions may be favorable for growth and development and yet that particular stalk has seemingly made no effort to produce an ear or a rudiment of on ear.

On the other hand many stalks may be found in a field where some external condition may account in a measure for their inability to produce grain. The factors which will be discussed 

in this experiment are those which $1 \mathrm{t} / \mathrm{presumed}$ might have an influence in producing sterility as. thickness of planting, inbreeding, lack of proper food supply, and an inherent hereditary characteristic.

\section{PIAN OF THE EXPERIHENT.}

The plan upon which this experiment was conducted was to find as many totally barren stalks as possible, cross them upon the good shoots by hand and afterwards make $\varepsilon_{\text {i }}$ detailed study of the stalks themselves.

The following year the grain so produced was to be planted in rows in which the stand was varied. Good ears having the least possible known hereditary/tendency were to be planted in the same plot and in the same manner as the ears having barren stalks as their sire.

All those produced from seed not possessing barren blood were to be detasseled thus allowing only pollen from those stalks having the barren tendency to fertilize the whole plot. In this way it was hoped that some data cauld be obtained on the ability of barren pollen to fertilize ears of corn in the open field and by planting those ears, to find out whether or not the barren tendency was transmitted in the same manner as from hand polldnated ears.

WORK IN 1908

In August of 1908 the writer began work on this 

experiment. In a plot of corn on the Experiment Station field of the University of lifscouri a number of shoots were bagged with paper bags before any silk had appeared. The same time careful search was made of the plot and many stalks which seemed that they would not produce an ear were tagged to serve as sources of barren pollen.

It is very difficult to say what will be a barren stalk at tasseling time for some stalks are very slow in putting out their shoots so that a large number of ears so marked and pollinated from individual stalks afterward had to be discarded owing to the fact that the male stalk used produced an ear. Before the pollinating period was over the number of ears being fertilized was reduced to nine in this manner. All of the nine stalks used as sources of polien did not show a sign of a shoot during the pollinating period. As soon as the silks were dry the string on the brgs were loosened in order to allow the ear better development and each stalk, both mother and pollen bearer was elso accurately tagged. After the corn had ripened the stalk bearing the ears and those which had produced pollen were taken from the field. Upon examination at that time it was found that six of the nine so-thought "barren" stalks had thrown a shoot and formed some grain. The other three were perfectly barren. This left then, only the three ears which could be used the following spring to produce pollen for the entire plot to be planted. All nine of the ears however, were saved on account of the fact that they 

were hand fertilized and had one stalk as their male parent. Since the chances are good that every ear of corn is fertilized from several other stalks rather then one, it was thought that these ears would serve better to represent corn without a barren tendency than good ears taken from the open field where the chances were good that some barren stalks had fertilized a part of them.

Hone of the ears so produced were at all good in shape; all the kernels however, were matured and fairly well developed so that good results vere expected from them. Every ear was carefully labelled with the number of its mother stalk and pollen stalk and laid away until the following spring.

THE WORK IN 1909.

In the spring of 1909 the nine ears of corn produced by hand pollination and another good ear which was chosen from the breeding corn work were planted in an fsolated plot. The nine ears of corn were numbers 29-129,43-114, 41-104, 30-103, 27-119, 26'-108, 36-110,32-102, and 25-101. The ear from the breeding plot was simply called a good car. The first number refers to the mother stalk and the last refers to the pollen bearing stalk. Of these nine only the first three proved to be the product of fertilization from barren stalks. Table I (1909) shows the order in whoh/various ears were planted. Four Hows were planted from each ear, the first 

ORDER OF PLAHTIHY OF CORN USED IN BARREN WORK SHOWING ROWS, EAPS USED FOR POLIEN AND DETASSELING, AID NUMBER OF STAIKS

PER HIII.

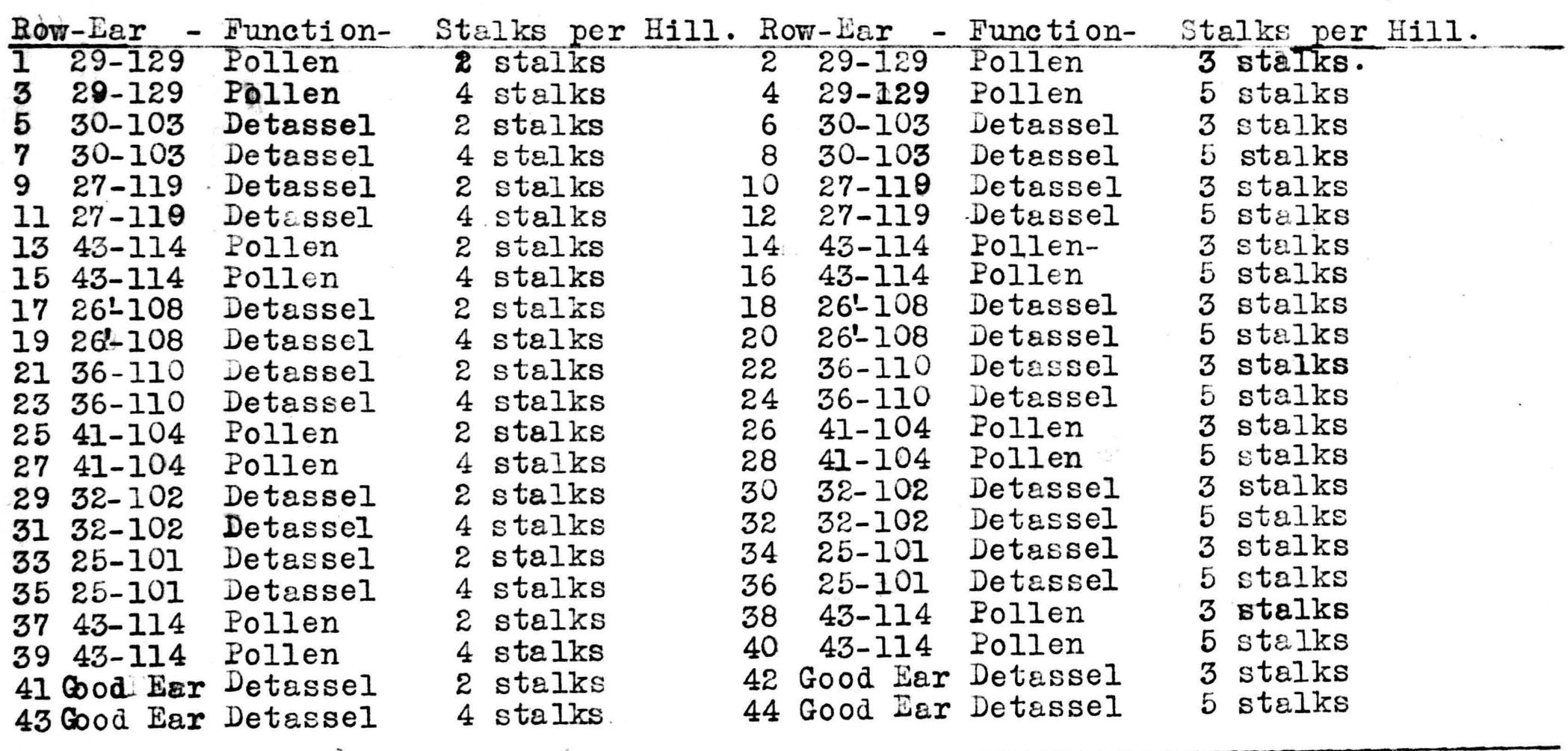

Planted May, 18, 1909.

Thinned to above stands, July 9.

Pows 15 hills long.

Hill 3 feet, -4 inches apart each wey. 

one to have two stalks per hill, second three, third four, and the fourth five stalks. More grains than necessary to produce this stand were planted in order that they might be thinned later end exactly such a stand produced if possible.

Since the number of ears fertilized from a barren stalk was so few, two good ears were inserted between each poor one thus making two rows to produce pollen and four to be detasseled followed by two for pollen. The rows were only fifteen hills long with those planted two and three stalks per hill and those to be four and five stalks respectively a end to end. The whole plot was laid out in diagram as shown by Table I.

The corn was thinned to the proper stand on July 9 th then cultivated until it too high to use a two-horse cultivator. Care was taken not to break down any more stelks than was absolutely necessary.

After tris corn was mature a count was made of the number of stalks which had come to maturity in each hill of each row. Table II shows the total number of stalks for each row which was to have two and four stalks per hill respectively. Table III shows the actual number of stalks per hill and the total for each row which wa to have three and five stalks per hill respectively.

A count was also made of the number ofrbarren stalks which occured in each row under the varying changes of stand. Table IV shows the total number barren stalks and the percent of 

SHOWING ACTUAL NUDBER OF STALIS PER HILI AT HARVEST TIME AIND TOTAL PER ROW. ROWS ODD IUUBERS AND PLAITED TO HAVE STAIID OF

2 \& 4 STALKS PER HIII RESPECTIVELY.

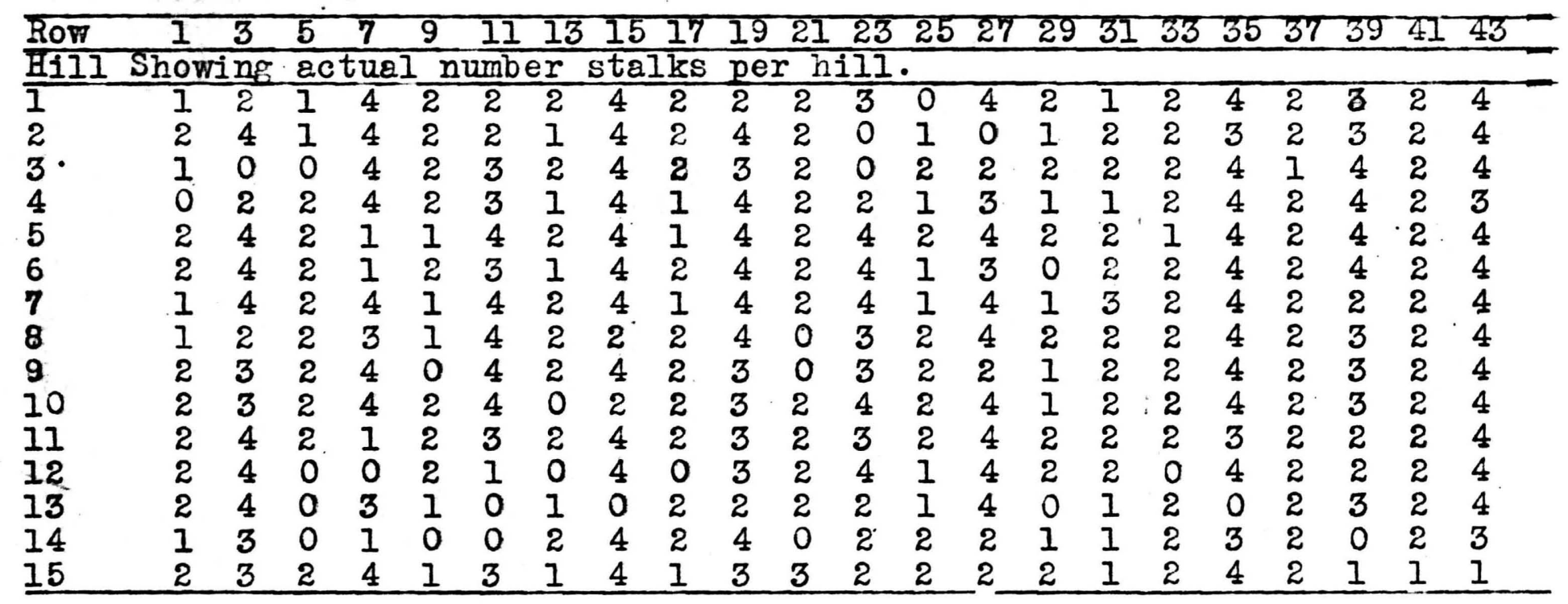

Tot $\begin{array}{llllllllllllllllllllll}23 & 46 & 20 & 42 & 21 & 40 & 21 & 52 & 24 & 50 & 25 & 40 & 22 & 46 & 20 & 26 & 27 & 53 & 29 & 41 & 29 & 55\end{array}$ al. 

TABIE III. (09).

SHOWING ACTUAL WUNBER OF SHALKS PLR HILL AT HARVEST TIE AIN TOTAL

PER ROW. ROWS EVEH NUBERS AND PLANTED TO HAVE STAID

OF 3 \& 5 STALKS PER HIIL RESPECTIVEIY.

\begin{tabular}{|c|c|c|c|c|c|c|c|c|c|c|c|c|c|c|c|c|c|c|c|c|c|c|}
\hline & 2 & $\frac{4}{1-n}$ & 6 & 81 & 101 & 12 & 141 & 16 & 18 & $20:$ & 22 & 24 & 26 & 28 & 30 & 823 & 34 & 36 & 38 & 403 & 42 & 44 \\
\hline & & & & ct & ual & & & & & $6 \mathrm{gl} \mathrm{ks}$ & & $\overline{p e r}$ & & aill & & & & & & & & \\
\hline 1 & 3 & 3 & 3 & 0 & 3 & 5 & 3 & $\overline{4}$ & 3 & 3 & 3 & 4 & $\overline{0}$ & 2 & 3 & 2 & 0 & 4 & 3 & 2 & 3 & 4 \\
\hline & 2 & 2 & 3 & 5 & 3 & 5 & 3 & 3 & 3 & 3 & 3 & 3 & 3 & 3 & 3 & 1 & 3 & 6 & 3 & 2 & 3 & 5 \\
\hline 3 & 3 & 3 & 3 & 4 & 1 & 5 & 2 & 4 & 1 & 4 & 3 & 5 & 3 & 5 & 3 & 0 & 3 & 4 & 3 & 3 & 3 & 4 \\
\hline 4 & 0 & 3 & 2 & 3 & 2 & 4 & 0 & 4 & 2 & 4 & 1 & 4 & 2 & 4 & 1 & 4 & & 5 & 2 & & 3 & 4 \\
\hline 5 & 3 & 3 & 3 & 5 & 3 & 1 & 0 & 5 & 3 & 3 & 3 & 4 & 3 & 5 & 3 & 2 & 3 & 6 & 3 & 4 & 3 & \\
\hline & 0 & 3 & 3 & 0 & 3 & 5 & 0 & 5 & 3 & 4 & 3 & 4 & 3 & 3 & 0 & 2 & 3 & 5 & 2 & 4 & 3 & 4 \\
\hline & 2 & 0 & 3 & 1 & 0 & 2 & 1 & 5 & 3 & 5 & 3 & 5 & 2 & 5 & 0 & 1 & 3 & 5 & 3 & 5 & 2 & 5 \\
\hline 8 & 0 & 0 & 3 & 4 & 3 & 3 & 2 & 2 & 3 & 3 & 3 & 3 & 3 & 3 & 2 & 2 & 3 & 4 & 1 & 5 & 3 & 5 \\
\hline & 1 & 4 & 3 & 5 & 3 & 4 & 2 & 3 & 3 & 3 & 2 & 4 & 3 & 4 & 1 & 1 & & & 3 & 5 & 3 & 5 \\
\hline 10 & 3 & 4 & 3 & 5 & 3 & 5 & 3 & 4 & 2 & 4 & 3 & 4 & 2 & 4 & 2 & 2 & 3 & 2 & 3 & 4 & $\frac{1}{0}$ & 4 \\
\hline 11 & 0 & $\begin{array}{l}0 \\
0\end{array}$ & $\begin{array}{l}3 \\
2 \\
2\end{array}$ & $\begin{array}{l}5 \\
5\end{array}$ & $\begin{array}{l}2 \\
2 \\
0\end{array}$ & $\begin{array}{l}3 \\
3\end{array}$ & 3 & 4 & $\underset{3}{2}$ & $\begin{array}{l}3 \\
3\end{array}$ & $\begin{array}{l}2 \\
3\end{array}$ & $\frac{7}{5}$ & 3 & $\frac{4}{3}$ & $\begin{array}{c}2 \\
2 \\
2\end{array}$ & $\begin{array}{l}1 \\
0\end{array}$ & $\begin{array}{l}3 \\
2 \\
2\end{array}$ & $\begin{array}{l}5 \\
5\end{array}$ & $\begin{array}{l}3 \\
2\end{array}$ & $\begin{array}{l}5 \\
2\end{array}$ & $\begin{array}{l}3 \\
3\end{array}$ & $\begin{array}{l}5 \\
4\end{array}$ \\
\hline $\begin{array}{l}12 \\
13\end{array}$ & $\frac{1}{2}$ & 4 & $\begin{array}{c}\alpha \\
2 \\
\end{array}$ & 5 & 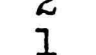 & $\begin{array}{l}0 \\
3\end{array}$ & I & $\begin{array}{l}4 \\
5\end{array}$ & $\begin{array}{l}0 \\
2\end{array}$ & $\begin{array}{l}0 \\
4\end{array}$ & $\begin{array}{l}0 \\
1\end{array}$ & 4 & 3 & 1 & $\tilde{2}$ & & & & 2 & 3 & 3 & \\
\hline 14 & 3 & 0 & 3 & 5 & 2 & 0 & 3 & 2 & 2 & 1 & 3 & 2 & 0 & 3 & 2 & 1 & 1 & 5 & 3 & 5 & 3 & 5 \\
\hline 15 & 0 & 5 & $\frac{2}{17}$ & $\frac{4}{56}$ & 1 & 5 & 2 & 3 & 1 & $\frac{3}{50}$ & $\frac{0}{36}$ & $\frac{2}{54}$ & $\frac{2}{34}$ & $4 \frac{5}{55}$ & $\frac{2}{29}$ & $\frac{1}{20}$ & $\begin{array}{c}2 \\
38\end{array}$ & $\frac{4}{68}$ & $\frac{2}{38}$ & $\frac{4}{57}$ & $\frac{3}{42}$ & $\frac{2}{65}$ \\
\hline
\end{tabular}



barrenness thrown by each row. It is well to note in this connection that nothing was called a barren stalks which had produced as much as one grain of corn. Those stalks which had produced rudimentary shoots without grain were included as barren.

Other data taken on the stalk characters of each row is shown in Table $v$. The height of stalk and its circumference give us a good idea of the constitutional vigor of the plants produced. The size and droop of the ears are viso good Indications of the productive ability of the stalks in question.

\section{DISCUSSION OF RESUITS FOR 1909.}

Hereditary Barrenness.

The actual number of barren stalks produced by each row is shown in Table IV.(09). Rows $1,2,3$, and 4 were from ear $29-129,13,14,15$ and 16 from ear 43-114, 25,26,27, and 28 from ear 41-104 and 37,38,39, and 40 from ear 43-114. It will be noticed that these ears produced a large number oi barren stalks, the average being much higher than the remaining rows although ear 25-101 threw a very large number of barren stalks especially in the row planted to four stalks per rill. In no case do the good ears exhibit the same uniform tendency to a high percent of barrenness as shown by the barren bred ears. Turning to Table VII (09) there is shown the total number of barren stalks produced both by barren bred seed and 

TABLE IV. (09).

SHOWING TOTAL NUMBER OF BARPEI STALKS AND PERCENT

OF BARREINESS FOR EACH ROW.

\begin{tabular}{|c|c|c|c|c|c|c|c|}
\hline S.OW. & $\begin{array}{l}\text { No. } \\
\text { stalks. }\end{array}$ & $\begin{array}{l}\text { Ho.barren } \\
\text { staiks. }\end{array}$ & $\begin{aligned} & \text { \% barren } \\
& \text { stalks. } \\
&\end{aligned}$ & Row. & $\begin{array}{l}\text { No. } \\
\text { sta } 1 \mathrm{ks} .\end{array}$ & $\begin{array}{l}\text { Wo. barren } \\
\text { stelks. }\end{array}$ & $\begin{array}{l}\text { jo barren } \\
\text { stalks. }\end{array}$ \\
\hline $\begin{array}{l}1 \\
3 \\
5 \\
7 \\
9 \\
11 \\
13 \\
15 \\
17 \\
19 \\
21 \\
23 \\
25 \\
27 \\
29 \\
31 \\
33 \\
35 \\
37 \\
39 \\
41 \\
43\end{array}$ & $\begin{array}{l}23 \\
46 \\
20 \\
42 \\
21 \\
40 \\
21 \\
52 \\
24 \\
50 \\
25 \\
40 \\
22 \\
46 \\
20 \\
26 \\
27 \\
53 \\
29 \\
41 \\
29 \\
55\end{array}$ & $\begin{array}{l}2 \\
10 \\
0 \\
2 \\
0 \\
9 \\
5 \\
22 \\
3 \\
27 \\
2 \\
5 \\
11 \\
31 \\
1 \\
2 \\
9 \\
31 \\
9 \\
20 \\
0 \\
8\end{array}$ & $\begin{array}{l}8.7 \\
21.7 \\
0.0 \\
4.8 \\
0.0 \\
22.5 \\
23.8 \\
42.3 \\
12.5 \\
54.0 \\
8.0 \\
12.5 \\
50.0 \\
67.4 \\
5.0 \\
7.7 \\
33.3 \\
58.5 \\
31.3 \\
48.8 \\
0.0 \\
14.5\end{array}$ & $\begin{array}{l}2 \\
4 \\
6 \\
8 \\
10 \\
12 \\
14 \\
16 \\
18 \\
20 \\
22 \\
24 \\
26 \\
28 \\
30 \\
32 \\
34 \\
36 \\
38 \\
40 \\
42 \\
44\end{array}$ & $\begin{array}{l}23 \\
34 \\
41 \\
56 \\
32 \\
53 \\
27 \\
57 \\
36 \\
50 \\
36 \\
54 \\
34 \\
55 \\
29 \\
20 \\
38 \\
68 \\
38 \\
57 \\
42 \\
65\end{array}$ & $\begin{array}{l}1 \\
5 \\
2 \\
8 \\
2 \\
11 \\
5 \\
26 \\
7 \\
23 \\
0 \\
7 \\
10 \\
24 \\
1 \\
2 \\
1 \\
26 \\
10 \\
20 \\
1 \\
5\end{array}$ & $\begin{array}{l}4.4 \\
14.7 \\
4.9 \\
14.3 \\
6.3 \\
20.4 \\
18.5 \\
45.6 \\
19.4 \\
46.0 \\
0.0 \\
12.9 \\
29.4 \\
43.6 \\
3.5 \\
10.0 \\
2.6 \\
38.23 \\
26.3 \\
35.1 \\
2.4 \\
7.7\end{array}$ \\
\hline
\end{tabular}



good seed when planted in the various thicknesses named. The rows planted to two stalks and four stalks per mill were side by side as were also those rows planted to three stalks and five stalks per hill respectively. There is considerable, and very constant differences in the amount of barrenness produced on each side of the plot showing a difference in soil. But seed of both barren bred and good ears were planted on the same soil at the same rate of planting. There is also a great difference in the percentage of barrenness produced from each class of seed. Table IX shows the ectual percentage of barrenness in each case. Since then the barren bred and good ears were planted on the same soil and at the same rate the difference in berrenness must be due to. the seed used. As shown by the table there was a difference of $19.39 \%$ with two stalks per hill, $15.80 \%$ with three stalks per hill, $17.41 \%$ with four stalks per hill and $14.54 \%$ with five stalks per hill.

How since the portion of the plot planted to three and five stalks per hill respectively seemed to/richer than the other side we would expect the amount of barrenness to decrease, which it did. Furthermore if the barren bred ears had any definite hereditary tendency we would not expect the number of barren stalks produced to keep up in exact percent with the increase in stend. In view of the se facts the difference in percentage of barrenness which is so much greater in the case of berren bred seed can only be ascribed to the seed. Whether or not this tendency is strictly an inherited 

TABLE V. (09):

SHOVIING STALK CHARACTERS OF EACH ROW.

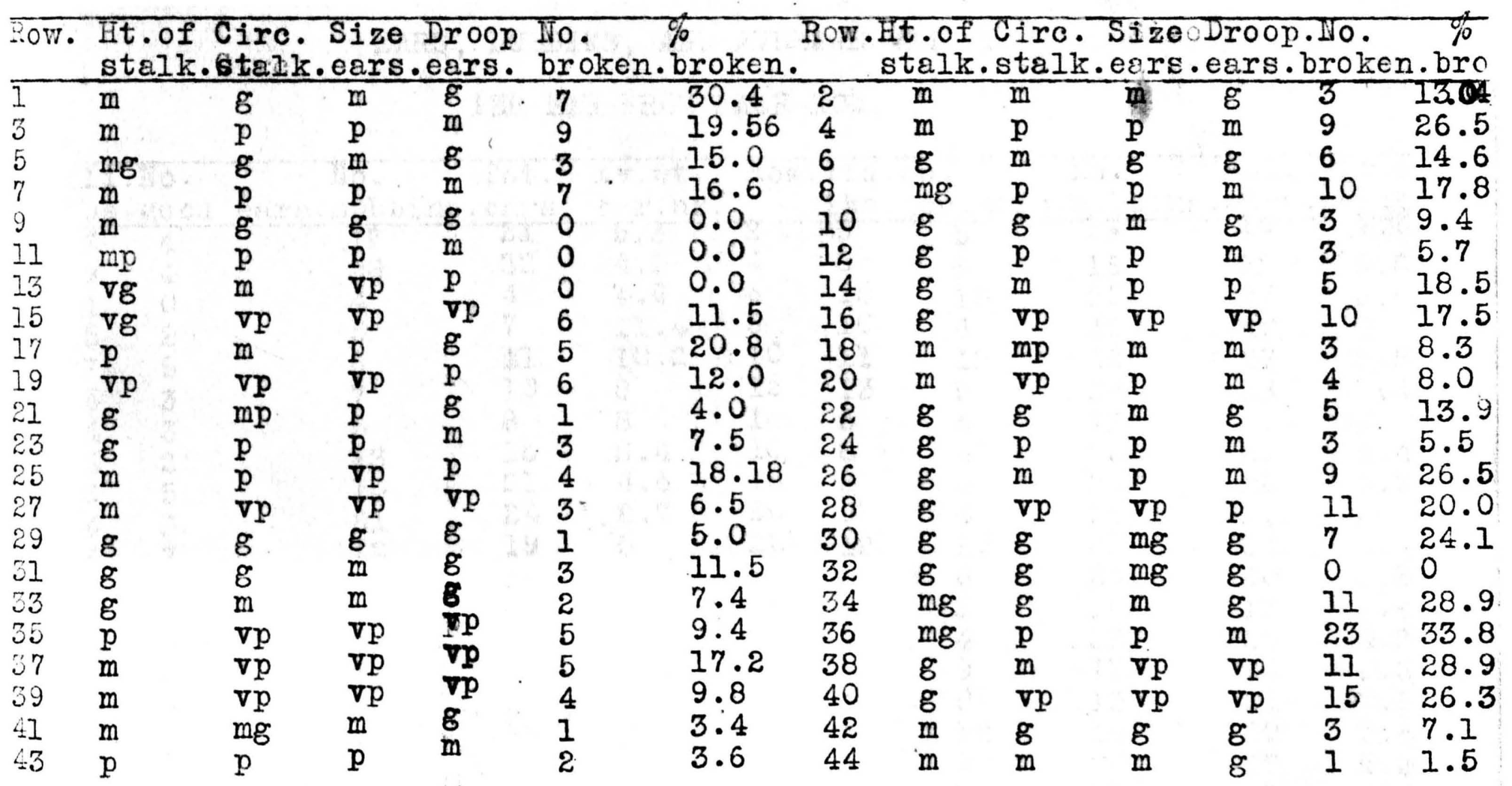

$\mathrm{v}=$ very good

$g=$ good

$\mathrm{mg}=$ medium good

$\mathrm{m}=$ medium

$\nabla p=$ very poor

p. $=$ poor

$\mathrm{mp}=$ medium poor 

TABLE VI.(1909)

SHOWING YIELD OP GRAIN INCLUDIHG IULERR ON GOOD

TARS, NUBBINS, AND AVEEAGE WEIGIT

PER EAR FRON EACH ROW.

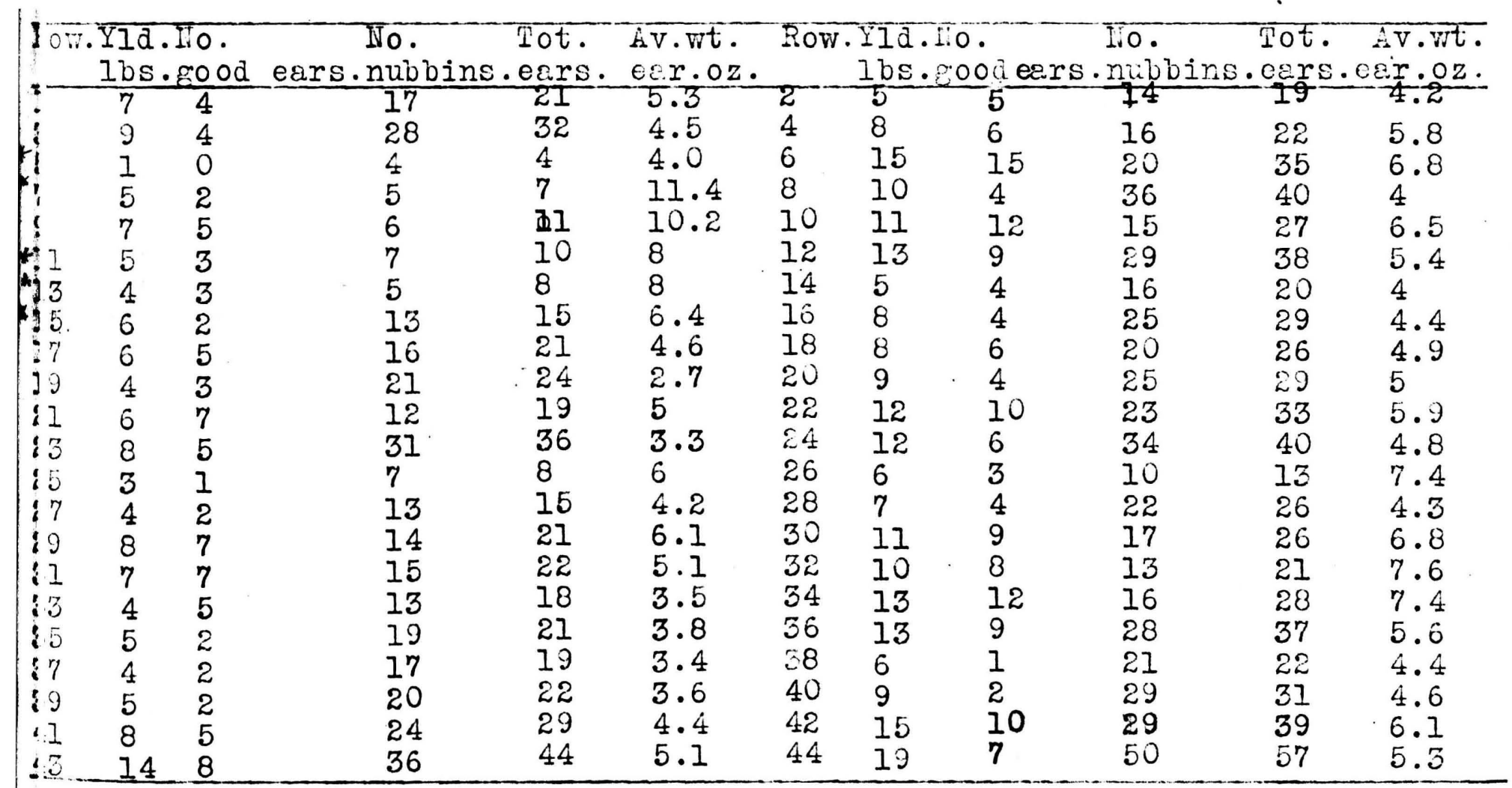

* Some ears eaten by cow. Dete worthless. 

TABIE VII. (O9).

SUTLRY O DATA OII BARTI VS. COOD ROWS LII

PIGURES AVIRAGES.

Average of Barren Stalks.

\begin{tabular}{|c|c|c|c|c|c|c|c|c|}
\hline & Average & of Barren & a stalks. & & Ever & rage of & frood Rows & \\
\hline Stand. & $\begin{array}{c}2 \\
\text { stalks. } \\
\end{array}$ & $\begin{array}{c}3 \\
\text { stalks. }\end{array}$ & $\begin{array}{c}4 \\
\text { stalks. }\end{array}$ & $\begin{array}{c}5 \\
\text { stelks. }\end{array}$ & $\begin{array}{c}8 \\
\text { stel } k s . \\
\end{array}$ & $\begin{array}{c}3 \\
\text { stelks. }\end{array}$ & $\begin{array}{c}4 \\
\text { ste } 1 \mathrm{ks} \text {. }\end{array}$ & $\begin{array}{c}5 \\
\text { stelks. }\end{array}$ \\
\hline $\begin{array}{l}\text { Motal } \\
\text { stalks. }\end{array}$ & 95 & 122 & 185 & 203 & 166 & 254 & 306 & 366 \\
\hline $\begin{array}{l}\text { Total } \\
\text { Earren }\end{array}$ & 27 & 26 & 83 & 75 & 15 & 14 & 84 & 82 \\
\hline $\begin{array}{l}\text { Percent } \\
\text { barren }\end{array}$ & 28.42 & 21.31 & 44.86 & 36.94 & 9.03 & 5.51 & 27.45 & 22.4 \\
\hline $\begin{array}{l}\text { Total } \\
\text { broken }\end{array}$ & 16 & 28 & 22 & 45 & 13 & 38 & 26 & 44 \\
\hline $\begin{array}{l}\text { percent } \\
\text { bro ken }\end{array}$ & $16.84=$ & 22.95 & 11.89 & 22.16 & 783 & 14.96 & 8.49 & 12.02 \\
\hline forinte: & 4.5 & 5.5 & 6 & 8 & 6.5 & 12.1 & 7.6 & 12.3 \\
\hline $\begin{array}{l}\text { ev. wt. } \\
\text { per ear. } \\
\text { ounces. }\end{array}$ & 5.14 & 4.75 & 4.17 & 4.74 & 5.25 & 6.32 & 4.14 & 5.26 \\
\hline
\end{tabular}



one is more the work this year has proven. It may be that fertilization from barren stalks weakens the vitality of the seed and the general virility of the plant thus causing barrenness. Since however, the ole plot was composed of good thrifty stalks and since no difficulty was encountered in getting the pollen grain to fertilize the silks the writer is strongly of the opinion that the results show that barrenness is an inherited and transmissable charecter.

\section{BARREINIESS DUE TO POOR SOIL I INCREASED STIND.}

As mentioned above there is a very constant difference in the percentage of varrenness between rows planted to two and four stalks per hill respectively and three and five stalks respectively. In the case of the barren bred ears (Table VII) the average percent of barren stalks for rows two stalks per hill was 28.42 , for four stalks 44.86 , difference 16.44\%. For all rows planted to three stalks per hill the average percent of barrenness was 21.31 end for five stalks was 36.94, difference 15.63\%. In case of the good ears the ififerences as above were $18.42 \%$ and $16.89 \%$ respectively. How, since the two and four stalk plantings were always on one side of the plot and the three and five stalk plantings on the other, it is obvious that some soll condition on the two and four stalk side must have been responsible for the increase in barrenness.

The supposition that the soil on the side of the 

plot planted with rows havine two stalks and four talks per

: hill was poorer than the other side is supported by the record or the yield of corn. As seen in rable VII the yield ol corn in all good rows averaged 6.5 pounds vith two stalks por hill, 12.1 pounds with trree stalks per hill, 7.6 pounds vith four stalks per hill, and 12.3 pounds with live stelks per hill. Instead of the yield increasing steadily with the stend or increasing to a certain point and then falline it is uniformily greater on the side of the plot planted three stalks and five stalks per hill respectively. This shows that tre soil must heve been richer there.

Since the increase in berrenness on the seme soil was so uniform with the increase in stand it seems that the percent of barrenness increases directly with the increase in stand. Taking the increase in total number ol stalks and totel number ol barren stalks from rows planted to two stalks per hill to four stalks per hill and iron triree to live stalks in both barren bred and good rovs the rates of increase in barren stalks to one stalk increase in the stand is 1:.62, $1: .49,1: .605$, and $1: .607$. The dverege is 1:.58. That is increasine the stend one stalk dads .58 of one barren stalk.

W1th this proportion the number of barren stalks can be corrected to both the good and poor soil found in this plot. Table VIII shows this correction for both barren bred and good ears to each soil.. With the correction made it is seen that the fertility of the soil must play a very important part in producing or reducing the number of barren stalks in a 

TABIE VIII. (1909).

SHOWING CORRECTIONS TO SAME SOIL CONDITIONS OF BOTH BARREN

AND GOOD EARS WITH DIFHERENCE IN \% OF BARRUNNESS

DUE TO SOII.

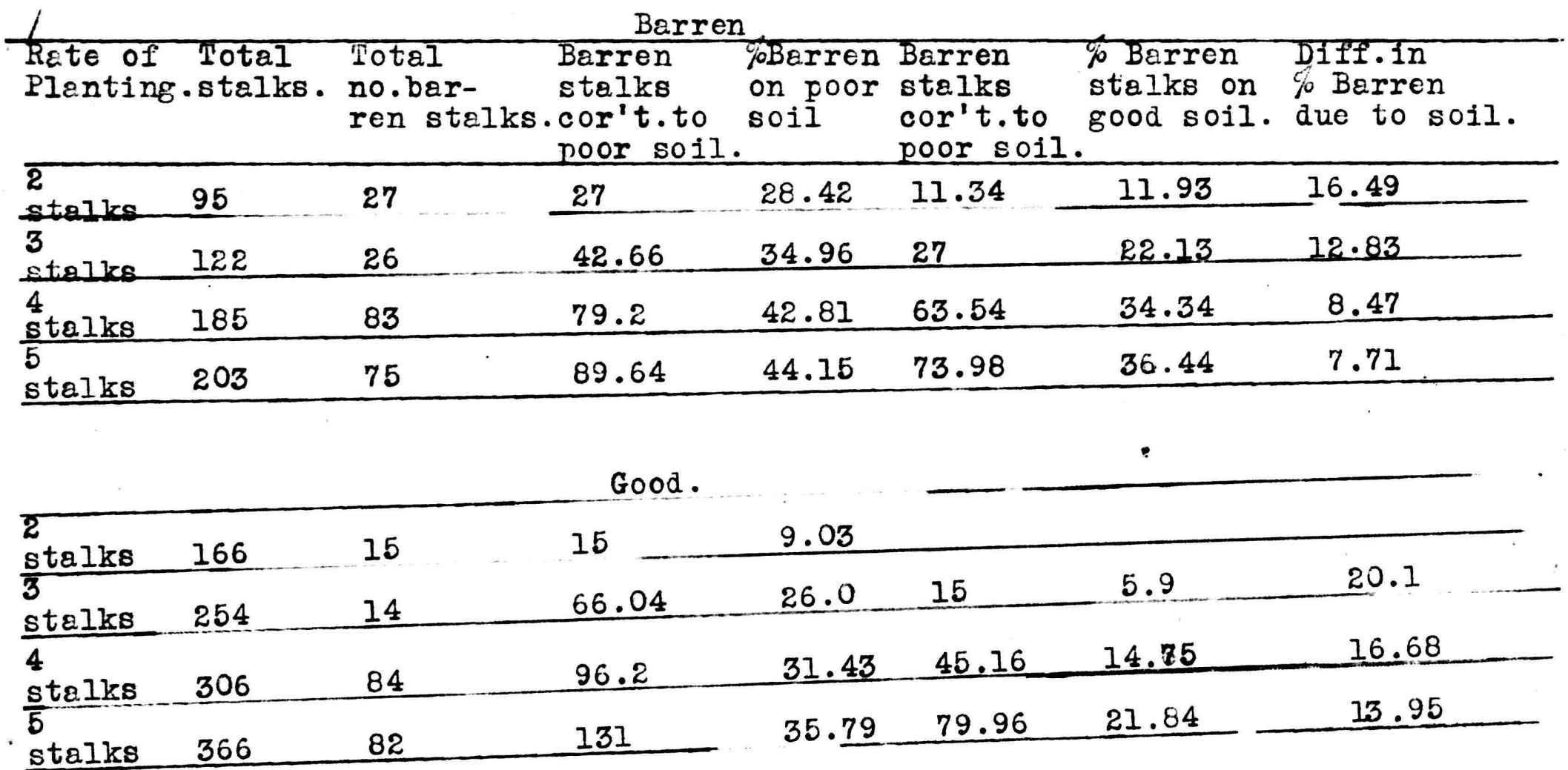



field of corn. The differences in percent of barrenness due to poor soil for barren bred ears were $16.49 \%$ rows plented two stalks $p \in r$ hill, $12.83 \%$, rows planted trree stelis per hill, $8.47 \%$ rows plented tour stelks per hill, and $7.71 \%$ rowe planted live stalks per hill. In the good rows it wes found thet the correction reduced the number oi barren stalks to a minus quentity for the good soil shoring that on a fertile soil a stand of two stalks $p \in r$ hill woula not have produced any barren stalks. This also showea that the barrenness observed in these rows wa due to incressing the stand and the soil conation. The eliect oi poor soil was even wore noticeable ranging from $20.1 \%$ varrenress due to poor soil with a stand of throe stalks per hill, $16.68 \%$ stand four stalks per hill, to $13.95 \%$ stani five stalks per hill. It is also to be noticed thet in thejase oi both verren bred and good ears on both good and poor soil thet tre nurber and percent of berren stalks increasca with the stend but that the percent due to soil declined with an increase in stand. this shoved that the influence of the poor soil was $\&$ fiairly constant thing and did not increase with the increase in stand.

THE EPTECT OF STAND ON STALK CHARACTERS.

Table $V$ shows tre characteristics of the stalks in cach row of the plot. It will be noticed that in every case the general vigor of both barren brea and good rows decreases as the stand increases. This is shown by lack of heicht, 

SHONING THE DIFHERENCE IN PERCENT OF BARRENINSS OF ROWS FRODUCHD FROL

SEED HAVING KNOWN BARPEI PARENTAGE AND GOOD SEED HAVING

FONE SO FAR AS KHOHN. DIFFERENCE IS DUE TO SEED

AS THE STRID IS EVEN GREATER AIN ON SAME SOII.

\begin{tabular}{|c|c|c|c|c|c|c|c|}
\hline $\begin{array}{l}\text { Rete of } \\
\text { Plenting }\end{array}$ & $\begin{array}{l}\text { Tot. } \\
\text { stalks } \\
\text { ber.rows }\end{array}$ & $\begin{array}{l}\text { Tot. } \\
\text { stalks } \\
\text {. good } \\
\text { rows. }\end{array}$ & $\begin{array}{l}\text { Bar. } \\
\text { telks } \\
\text { in Bar. } \\
\text { rows. }\end{array}$ & $\begin{array}{l}\text { Bar. } \\
\text { stelks } \\
\text { in good } \\
\text { rows. }\end{array}$ & $\begin{array}{l}\text { \% Barren } \\
\text { stalks } \\
\text { bar.rows. }\end{array}$ & $\begin{array}{l}\% \text { barren } \\
\text { stalks } \\
\text { good rows. }\end{array}$ & $\begin{array}{l}\text { Diff.in } \\
\text { barrenness } \\
\text { due to seed. }\end{array}$ \\
\hline \multirow{4}{*}{$\begin{array}{l}2 \\
\text { stalks } \\
3 \\
\text { stalks } \\
4 \\
\text { stalks } \\
5 \\
\text { stalks. }\end{array}$} & 95 & 166 & 27 & 15 & 28.42 & 9.08 & 19.39 \\
\hline & 122 & 254 & 26 & 14 & 21.31 & 5.51 & 15.80 \\
\hline & 185 & 306 & 83 & 84 & 44.86 & 27.45 & 17.41 \\
\hline & 203 & 366 & 75 & 82 & 36.94 & 22.4 & 14.54 \\
\hline
\end{tabular}



smaller circumference of stalk, less size and droop of ear, and an increase in the number of broken stalks which indicated smaller weaker joints and internodes. The weakening of the vitality and vigor of the plants must then be the cause of barrenness induced by thickening the stand.

OTHER WORK DONE IN 1909.

Further hand polldination was done this season. A wider range in numbers and types of barren stalks was avilable and much better ears were secured.

\section{A New Pollinator.}

Such poor ears were secured with the paper bags that the writer decided that they must present some mechanical obstruction to the growth of the ears. It was thought that they had two objectionable features, one that they became very hot inside and that a large percent of pollen applied to the silks was deritalized by the heat, and second that after the ear had been fertilized no scheme could be devised for holding the bags in place other than tying them around the ear. This caused a constriction and a poorly developed ear. In making a new pollinator the writer decided on cloth because of ease of handling and tying. A quantity of corn pollen was secured and placed on various pieces of cloth and put under a microscope. An attempt wes then made to force the pollen grainsthrough the meshes of the cloth. Tro kinds a very fine silk, and a good grade of canton flannel with the 

nap turned out would not allow pollen to go through. Bags about a foot lone and six inches in diameter were made from each of these materials. They had a araw string in the large end to regulate the size ol the opening and to tie around the stalk. At the small end a glass tube was inserted which had been reamed out at one end to prevent its slipping out. (The accompanying photograph shows a canton flannel pollinator). These bags were slipped over good shoots betore the silks appeared and tied to the stelk. As soon as the silks began to come pollen was gathered from a barren stalk previously selected and carried in a flat covered pan to the ear to be fertilized. Ine pollen was poured into the tube and a puff of breath down the tube sent it flying over the silks. By this plan the bags once in place are never removed and all danger of wild pollen is eliminated. Care was taken to loosen the draw strine each day as the ear was forming in order not to constrict the ear around the butt. Good ears of corn were secured this season as shown by the photograph. Those ears not well formed are probably so because of a lack of pollen to finish them out. Most of the stalks used as sires finished shedding their pollen before all the silks were out.

It is well to note here that the canton flannel bags proved to be the best as the silk ones rot and the grass hoppers eat them badly. 

BEGINNING THE WORK ON IIBREEDING.

In order to determine the effect of inbreeding on barrenness a plot of line bred corn was used for the purpose. In the Boone County White breeding work of this Stetion, two exceptionally good strains were found which we will call 10 and 67 . The object was to cross these and inbreed 10 at the same time then pile up the blood of 10 in the outcross by line breeding methods. In the season of 1909 only one ear of the cross and one of the inbred 10 were secured.

Inbreeding was also done in the plot devoted to the barren work. Care was taken to fertilize some ears from a barren stalk haying the same parentage as the ears. Thus ears 12-25 and 17-17 of 1910 were inbred coming from mother ears 41-104 and 32-102 of 1909 respectively. Arenort of results secured by inbreeding appears under the work done in 1910.

\section{WORK DONE IN 1910.}

Five ears barren bred were secured in 1909 which were made to furnish pollen for the 1910 plot. (See photograph of ears). One good ear number $9-6$ of the corn breeding work which had not throw a single barren stalk was used as a check. Also three ears open fertilized in the plot of 1909 were used but detasseled.

In the plot of 1910 there were then strictly barren bred ears, ears open fertilized from pollen produced by stalks which had been previously barren bred, and a tested ear from the breoding work which had not throvm any barren stalks. 

TABTE I. T7970)

ORDER OF PLANTING OF CORI USED IN BARREN WORK SECOND YEAR, SHOWIMG

ROWS, EARS USED FOR POLIEN AND DETASSELING, AND NUMBER OF

STAIKS PER HIIL.

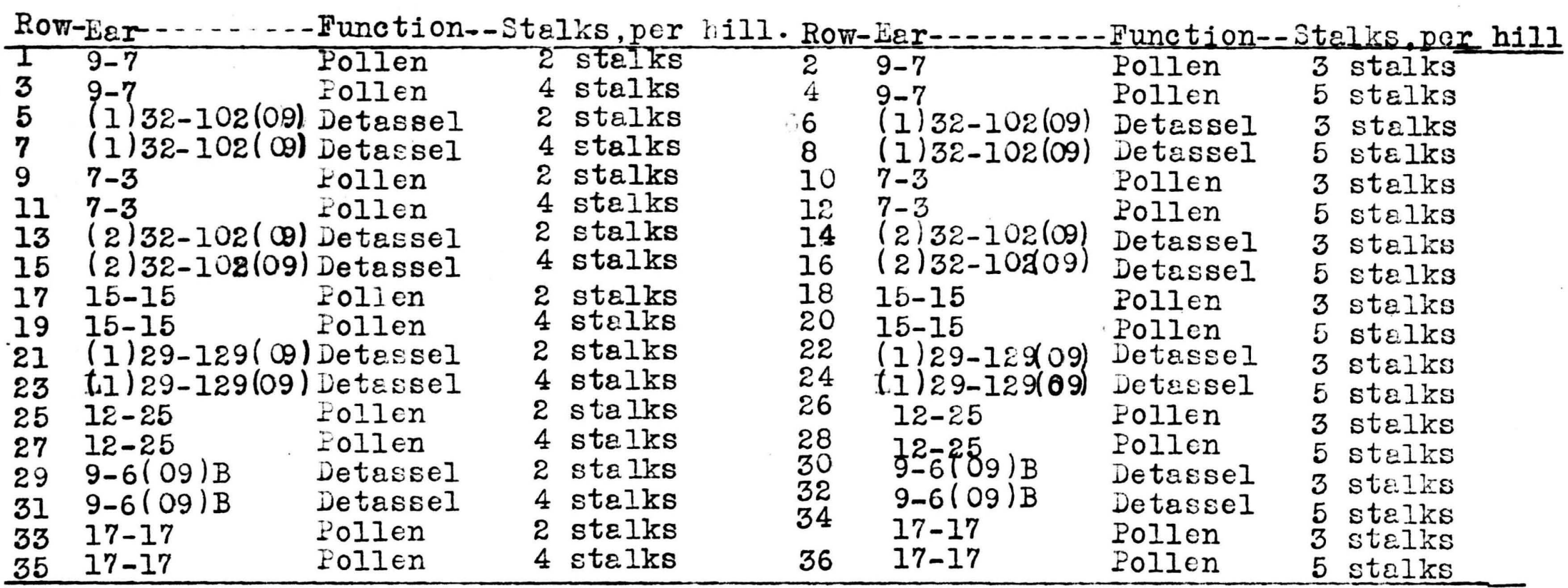

Planted Hay $31,1910$.

Thinned to cbove stands, July 8.

Rows 18 hills long.

Hills 3 feet, 4 inches apert each way. 

SHOWING ACTUAL NUIBER OF STALKS PER EIII AT HARVEST AID TOTAI PER ROW.

ROWS PLANTED TO HAVE STAND OF 2 \& 4 STALKS PER HIII RESPECIIVEIY.

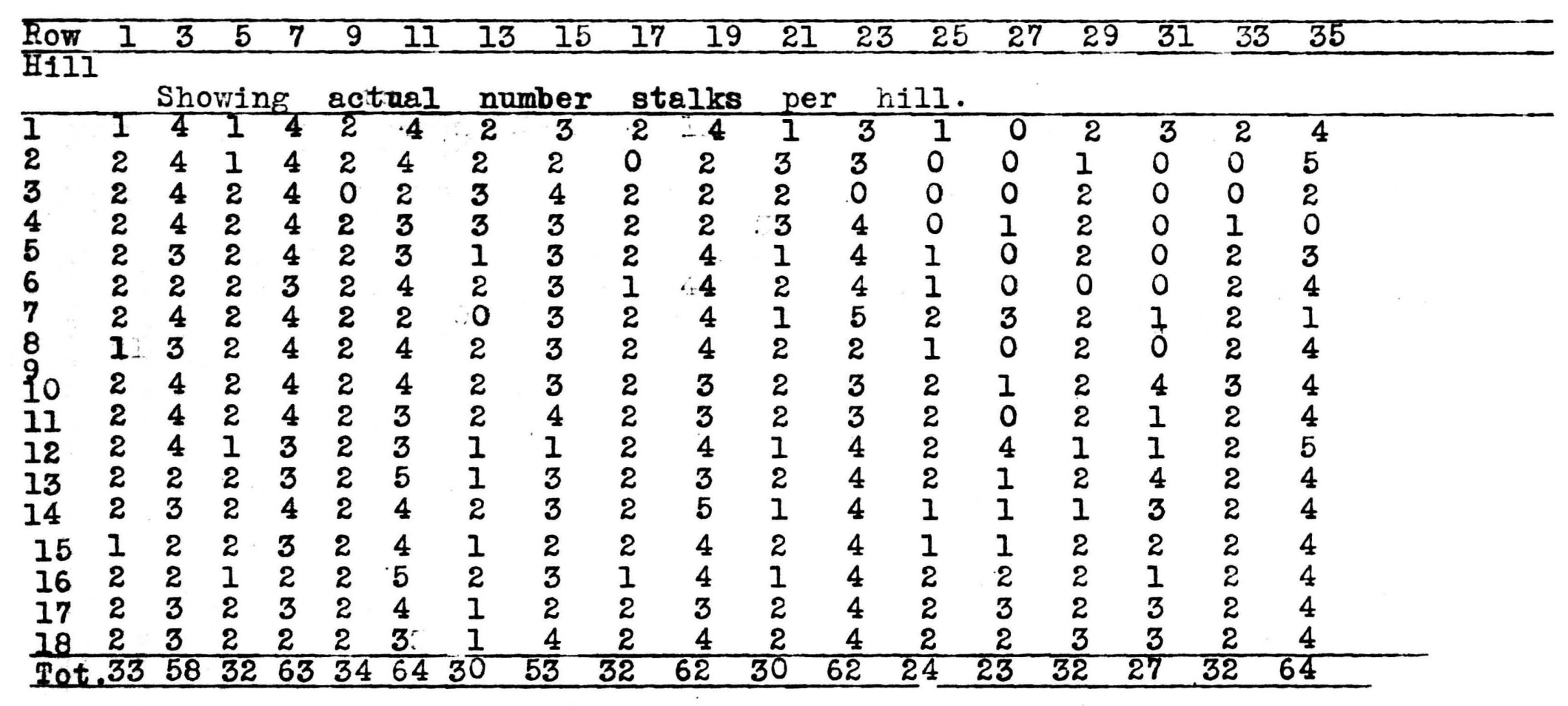

ֻั 

TABLE III (1910):

SHOWING ACTUAI NUMBER OF STAIKS PER IIIL AT HARVEST AND TOTAL PER ROW. ROWS PLANTED TO HAVE STAND OF 3 \& 5 STAIKS PER HIIL RESPECTIVELY.

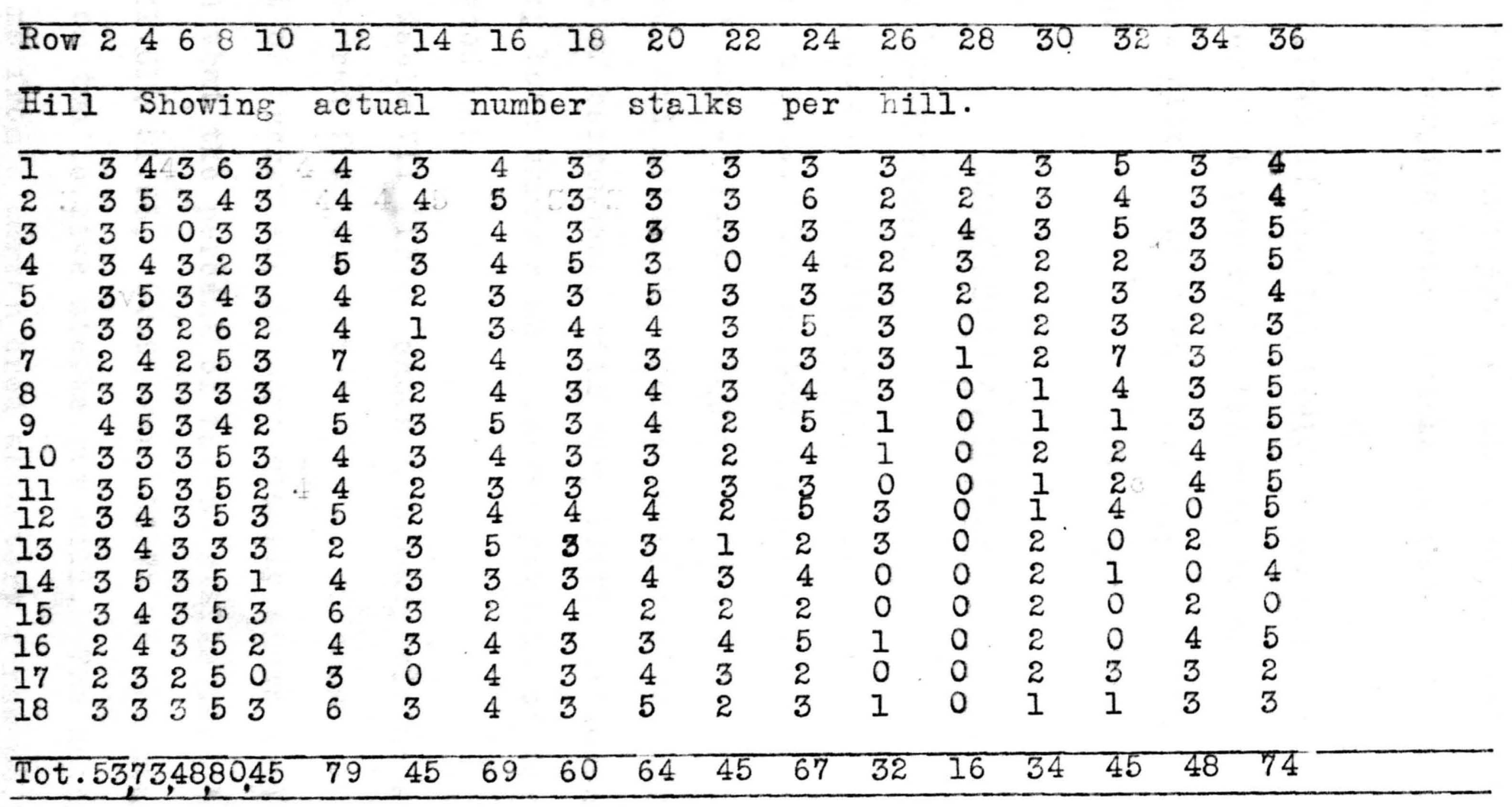



The order of planting, Table I (1910), and ranges in stand wexectly the same as for 1909. The soil was all good though sloping considerably to the north. The slope rains

afterward caused considerable damage by/washing out some of the rows and burying some kernels so deep that they never came up.

Tables II and III (1910) show the actual number of stalks per hill per fow which came to maturity in each rov of the whole plot. The totals are used throughout the following tables.

DISCUSSION OF RESULTS FOR 1910.

Hereditary Berrenness.

A count was made of all barren stalks in each row exactly as in 1909. The number and percent of barren stalks appear in Table IV (1910). A glance will show that the barren bred, and naturally crossed ears are exceedingly high in percent of barrenness, with very little difference between them. They both threw a much larger percent of barren stalks than the good ear.

Table VII (1910) shows a summary of the average results secured from the three classes of ears. The differences in percent of barrenness is more clearly shown in Table VIII(1910). It is seen that the percent of barren stalks from barren bred ears run $31.61,51.68,50.92$ and 63.72 as the stand increases from two to five stalks per hill. The naturally crossed ears from a barren bred ancestery threw 44.56, 50.72, 

TABIE IV. (1910).

SHOWING TOTAL IUNBER OF BARREN STALKS AND PERCLIT OF BARREMIESS FOR EACH ROW.

\begin{tabular}{|c|c|c|c|c|c|c|c|}
\hline Row. & $\begin{array}{l}\text { No. } \\
\text { stalks. }\end{array}$ & $\begin{array}{l}\text { No. } \\
\text { barren. }\end{array}$ & $\begin{array}{l}\% \\
\text { barren. }\end{array}$ & Row. & $\begin{array}{l}\text { No. } \\
\text { stalks. }\end{array}$ & $\begin{array}{l}\text { No. } \\
\text { barre }\end{array}$ & $\begin{array}{l}\% \\
. \text { barren }\end{array}$ \\
\hline $\begin{array}{l}1 \\
3 \\
5 \\
7 \\
9 \\
11 \\
13 \\
15 \\
17 \\
19 \\
21 \\
23 \\
25 \\
27 \\
29 \\
31 \\
33 \\
35\end{array}$ & $\begin{array}{l}33 \\
58 \\
32 \\
62 \\
34 \\
64 \\
30 \\
52 \\
32 \\
62 \\
30 \\
62 \\
24 \\
23 \\
32 \\
27 \\
32 \\
64\end{array}$ & $\begin{array}{l}5 \\
25 \\
16 \\
27 \\
13 \\
40 \\
10 \\
28 \\
16 \\
28 \\
15 \\
35 \\
9 \\
12 \\
6 \\
5 \\
6 \\
33 \\
\end{array}$ & $\begin{array}{l}15.15 \\
43.1 \\
50.0 \\
43.55 \\
38.24 \\
62.5 \\
33.3 \\
53.85 \\
50.0 \\
45.16 \\
50.0 \\
56.45 \\
37.5 \\
52.17 \\
17.7 \\
18.5 \\
17.7 \\
51.56\end{array}$ & $\begin{array}{l}2 \\
4 \\
6 \\
8 \\
10 \\
12 \\
14 \\
16 \\
18 \\
20 \\
22 \\
24 \\
26 \\
28 \\
30 \\
32 \\
34 \\
36 \\
\end{array}$ & $\begin{array}{r}53 \\
73 \\
48 \\
80 \\
45 \\
79 \\
45 \\
69 \\
60 \\
64 \\
45 \\
67 \\
32 \\
16 \\
34 \\
45 \\
48 \\
74 \\
\end{array}$ & $\begin{array}{l}11 \\
35 \\
19 \\
43 \\
18 \\
44 \\
21 \\
39 \\
37 \\
41 \\
30 \\
53 \\
25 \\
13 \\
9 \\
17 \\
32 \\
62 \\
\end{array}$ & $\begin{array}{l}20.75 \\
47.95 \\
39.59 \\
53.75 \\
40.0 \\
55.7 \\
46.68 \\
56.52 \\
61.67 \\
64.06 \\
66.66 \\
79.1 \\
78.12 \\
81.27 \\
26.47 \\
37.78 \\
66.67 \\
83.78 \\
\end{array}$ \\
\hline
\end{tabular}



TABIE : V. (1910).

SHOWING STALK CEARACILRS OF EACH ROW.

\begin{tabular}{|c|c|c|c|c|c|c|c|c|c|c|c|}
\hline$\pi / 7$ & $\sqrt{i g}$ & $\begin{array}{l}\text { Size } \\
\text { ears }\end{array}$ & $\begin{array}{l}\text { Droop } \\
\text { ears. }\end{array}$ & $\begin{array}{l}\text { wo. } \\
\text { broken } \\
\text { stalks }\end{array}$ & $\begin{array}{l}\% \\
\text { bro ken } \\
\text { stalks }\end{array}$ & Row. & Iig & $\begin{array}{l}\text { Sizt } \\
\text { eers }\end{array}$ & $\begin{array}{l}\text { Jroop } \\
\text { eqrs. }\end{array}$ & $\begin{array}{l}\text {.o. } \\
\text { broken } \\
\text { stel ks }\end{array}$ & $\begin{array}{l}\% \\
\text { broken } \\
\text { sta lks }\end{array}$ \\
\hline I & $\mathrm{m}$ & $m p$ & $\mathrm{p}$ & 3 & 9.09 & 2 & $p$ & $\mathrm{p}$ & $\nabla p$ & 6 & 11.32 \\
\hline 3 & $m p$ & $\mathrm{p}$ & $\mathrm{vp}$ & 11 & 18.96 & 4 & $\mathrm{vp}$ & vp & $\mathrm{vp}$ & 4 & 5.48 \\
\hline 5 & $\mathrm{vp}$ & $p$ & $\mathrm{vp}$ & 1 & 3.1 & 6 & $\mathrm{VY}$ & $p$ & $\mathrm{vp}$ & 1 & 2.08 \\
\hline 7 & $\mathrm{vp}$ & $\mathrm{vp}$ & $\mathrm{vp}$ & 4 & 6.45 & 8 & $\nabla p$ & $\mathrm{p}$ & $\mathrm{VP}$ & 2 & 2.5 \\
\hline 9. & $\mathrm{~m}$ & $\mathrm{mp}$ & $\mathrm{p}$ & 3 & 8.82 & 10 & $m p$ & $m p$ & $\mathrm{vp}$ & 0 & 0.0 \\
\hline 1.: & $m p$ & $\mathrm{vp}$ & $\mathrm{vp}$ & 6 & 9.37 & $\cdot 12$ & $\mathrm{mp}$ & $\mathrm{p}$ & $v p$ & 5 & 6.33 \\
\hline 23 & $m p$ & $\mathrm{~m}$ & $m p$ & 1 & 3.33 & 14 & $\mathrm{vp}$ & $\mathrm{vp}$ & $\mathrm{vp}$ & 3 & 6.66 \\
\hline 715 & $m p$ & $\mathrm{mp}$ & $m p$ & 4 & 7.69 & 16 & $\mathrm{vp}$ & $\nabla p$ & $\mathrm{vp}$ & 4 & 5.8 \\
\hline $1^{11}$ & $\mathrm{mg}$ & $\mathrm{mp}$ & $\mathrm{p}$ & 1 & 3.12 & 18 & $\mathrm{p}$ & $\nabla p$ & $\mathrm{vP}$ & 6 & $10 \% 0$ \\
\hline 1:) & $\mathrm{m}$ & $p$ & $\mathrm{vp}$ & 2 & 3.22 & 20 & $\mathrm{p}$ & $\mathrm{vp}$ & $\mathrm{vp}$ & 7 & 10.97 \\
\hline$E$ & $m p$ & $\mathrm{vp}$ & $\mathrm{vp}$ & 7 & 23.33 & 22 & $\mathrm{vp}$ & $\mathrm{vp}$ & $\mathrm{vp}$ & 6 & 73.33 \\
\hline 23 & $\mathbf{p}$ & $\mathrm{vp}$ & $\mathrm{vp}$ & 4 & 6.45 & 24 & $\mathrm{vp}$ & $\mathrm{vp}$ & $\mathrm{vp}$ & 9 & 13.43 \\
\hline ( $i i)$ & $m p$ & $\mathrm{p}$ & $\mathrm{vp}$ & 1 & 4.16 & 26 & $\mathrm{vp}$ & $\mathrm{vp}$ & $\mathrm{vp}$ & 0 & 0.0 \\
\hline Ei & $\mathrm{mp}$ & $\mathrm{vp}$ & $v p$ & 1 & 4.35 & $\begin{array}{l}28 \\
30\end{array}$ & $\mathrm{vp}$ & $\mathrm{vp}$ & $\mathrm{vp}$ & 1 & 6.25 \\
\hline E! & $\mathrm{mg}$ & $\mathrm{mg}$ & 8 & 8 & 25.0 & 30 & $\mathrm{p}$ & $\mathrm{vp}$ & $\mathrm{vp}$ & 3 & 8.18 \\
\hline 8 & $m p$ & $m p$ & $\mathrm{~m}$ & 4 & 14.81 & 32 & $p$ & $\nabla p$ & $\mathrm{Vp}$ & 9 & 20.0 \\
\hline 23 & $m g$ & $m p$ & $\mathrm{p}$ & 1 & 3.12 & 34 & $\mathrm{p}$ & $\nabla \bar{p}$ & $\mathrm{vp}$ & 0 & 0.0 \\
\hline (6) & $m g$ & $\mathrm{p}$ & $\mathrm{vp}$ & 3 & 4.69 & 36 & $\mathrm{p}$ & $\mathrm{vp}$ & $\mathrm{vp}$ & 2 & 2.7 \\
\hline
\end{tabular}



TABIE VI. (1910)

HE NING YIELD OF GRAII INCLUDING IUUBER OF GOOD EARS, NUEBIIS, WEIGIT TODDER, AND AVERAGE WEIGH'T PER EAR FRON EACH ROM.

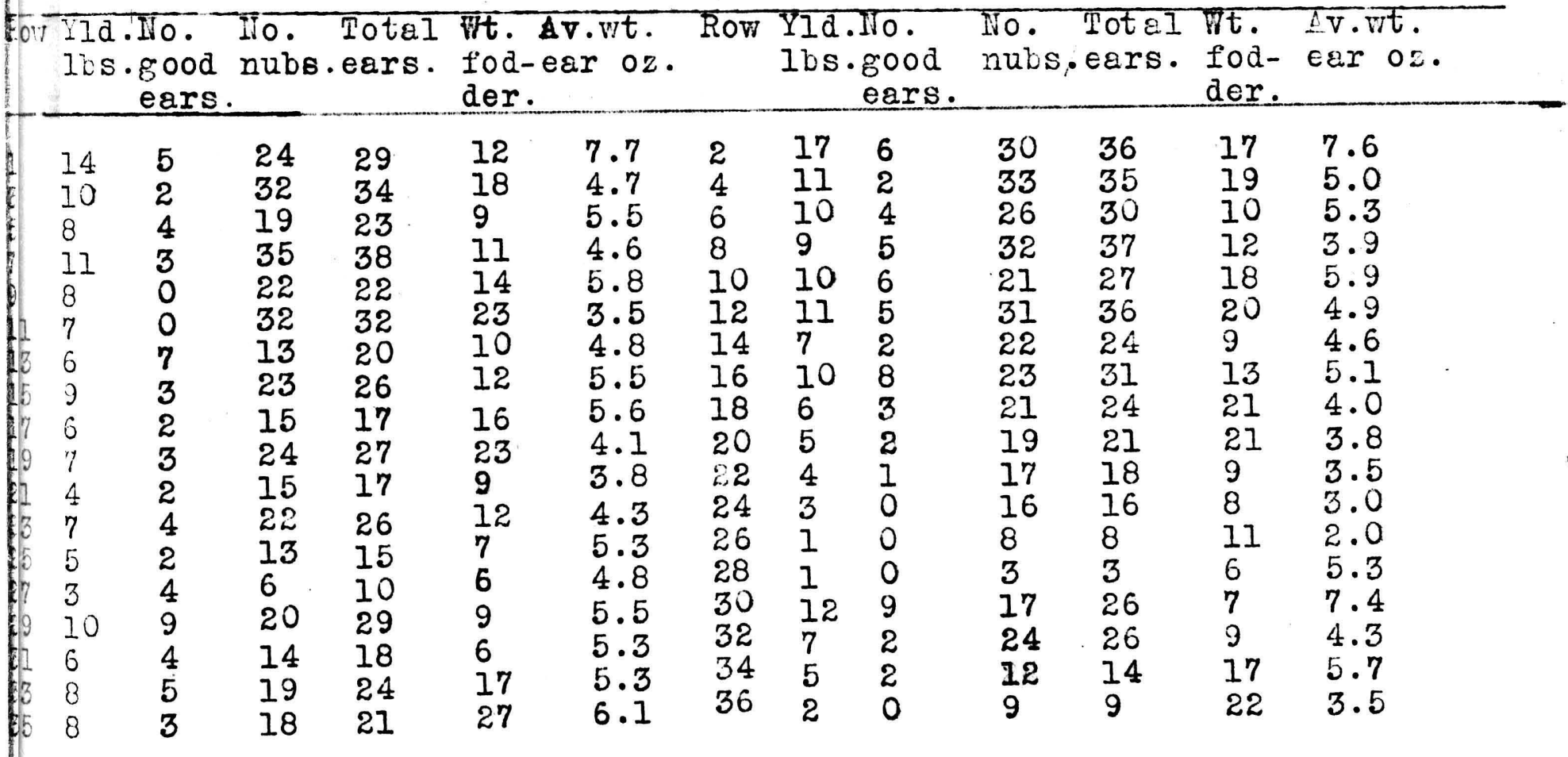

Ijte. The number of ears plus the number of barren stalks produced if each row may be the same, greater or less than the total number $0:$ stalks per row. If greater some stalks have produced twin ears. ii lere less those nubbins producing a grain or two have been over loked at husking time. 



\section{1}

TABIE VII. (1910).

SUMMARY OF DATA ON BARREH, PART EARREH, AND GOOD ROWS.

ALI FIGURE AVERAGE.

\begin{tabular}{|c|c|c|c|c|c|c|c|c|}
\hline Stand. & $\begin{array}{l}\text { Total } \\
\text { stalks }\end{array}$ & $\begin{array}{l}\text { Total } \\
\text { barren. }\end{array}$ & $\begin{array}{l}\% \\
\text { berren. }\end{array}$ & $\begin{array}{l}\text { Total } \\
\text { broken. }\end{array}$ & broken & $\begin{array}{l}\text { Av.VI } \\
. \mathrm{Ibs} .\end{array}$ & $\begin{array}{l}\text { Av.vt. } \\
\text { ear as. }\end{array}$ & $\begin{array}{l}\text { Increase in } \\
\text { barrenness } \\
\text { per I stalk } \\
\text { in stand. }\end{array}$ \\
\hline stalks & 155 & 49 & 31.61 & 9 & 5.8 & 8.2 & 6.1 & . \\
\hline stalks & 238 & 123 & 51.68 & 12 & 5.04 & 7.8 & 6 & $1: .9$ \\
\hline $\begin{array}{l}\text { stalks } \\
5\end{array}$ & 271 & 138 & 50.92 & 23 & 8.49 & 7 & 4.5 & $1: .76$ \\
\hline stalks & 306 & 195 & 63.72 & 19 & 6.21 & 6 & 4.6 & $1: .96$ \\
\hline${ }_{3}$ talks & 92 & 41 & 44.56 & 9 & 9.78 & 6.0 & 4.8 & \\
\hline stalks & 138 & 70 & 50.72 & 10 & 7.25 & 7.0 & 4.7 & $1: .63$ \\
\hline stalks & 176 & 90 & 51.13 & 12 & 6.82 & 9.0 & 4.8 & $1: .58$ \\
\hline $\mathrm{stalks}^{\text {talks }}$ & 216 & 135 & 62.6 & 15 & 6.94 & 7.3 & 4.2 & $1: .75$ \\
\hline 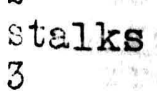 & 32 & 6 & 18.75 & 8 & 25.0 & 10 & 5.5 & \\
\hline stalks & 34 & 9 & 26.47 & 3 & 8.8 & 12 & 7.4 & $1: 1.15$ \\
\hline $\begin{array}{l}\text { talks } \\
5\end{array}$ & 27 & 5 & 18.51 & 4 & 14.8 & 6 & 5.3 & $1: .2$ \\
\hline stalks & 45 & 17 & 37.77 & 9 & 20.0 & 7 & 4.3 & $1: .84$ \\
\hline
\end{tabular}



TABIE VIII. (1910).

SHOWING THE DIFFERENCE IN BERCEIT OF BARRENUESS OF ROIS PRODICED FRON

SEED HAVING KIYOWIS BARREI PARENISGE, SEED NATURALIY CROSSED TRON!

A PREVIOUS EARREN CROSS, AND GOOD SEED.

\begin{tabular}{|c|c|c|c|c|}
\hline $\begin{array}{l}\text { Rate of } \\
\text { lenting }\end{array}$ & 2 stalks. & 3 stalks. & 4 stalks. & 5 stalks. \\
\hline $\begin{array}{l}\text { Total } \\
\text { ctalks } \\
\text { barren } \\
\text { rovs. }\end{array}$ & 155 & 238 & 271 & 306 \\
\hline $\begin{array}{l}\text { Total } \\
\text { pt.bar- } \\
\text { ren rows }\end{array}$ & 92 & 138 & 176 & 216 \\
\hline $\begin{array}{l}\text { otel } \\
\text { stalks } \\
\text { good rows }\end{array}$ & 32 & 34 & 27. & 45 \\
\hline $\begin{array}{l}\text { Darren } \\
\text { stalks in } \\
\text { barren rors }\end{array}$ & 49 & 123 & 138 & 195 \\
\hline $\begin{array}{l}\text { No.Barren } \\
\text { stalks in } \\
\text { pt.barren } \\
\text { rows. }\end{array}$ & 41 & 70 & 90 & 135 \\
\hline $\begin{array}{l}\text { lo. Barren } \\
\text { stalks in } \\
\text { good rows. }\end{array}$ & 6 & 9 & 5 & 17 \\
\hline $\begin{array}{l}\text { Tarren } \\
\text { stalks in } \\
\text { barren rows. }\end{array}$ & 31.61 & 51.68 & 50.92 & 63.72 \\
\hline $\begin{array}{l}\text { Barren } \\
\text { stalks in } \\
\text { nt.barren rows }\end{array}$ & 44.66 & 50.72 & 62.18 & 62.6 \\
\hline $\begin{array}{l}\text { \%arren } \\
\text { ctalks in } \\
\text { good rows. }\end{array}$ & 18.75 & 26.47 & 18.51 & 37.77 \\
\hline $\begin{array}{l}\text { Diff. favor } \\
\text { barren.Barren } \\
\text { vs.pt.barren. }\end{array}$ & -12.95 & +0.96 & +0.21 & +1.12 \\
\hline $\begin{array}{l}\text { Diff.favor } \\
\text { barren.Barron } \\
\text { vs.good. }\end{array}$ & +12.86 & +25.21 & +32.41 & +31.95 \\
\hline
\end{tabular}



51.13, and 62.6 percont barrenness as the stand increased from two to five stalks per hill. While the good ear only threw 18.75, 26.47, 18.51 and 37.77 percent of barren stalks as the stand increased from two to five stalks per hill. $A_{s}$ shown by the table there is a difference of $12.95 \%$ and $0.21 \%$ barrenness in favor of the naturally crossed ears over barren bred ones having a stand of two stalks and four stalks respectively. In case of three and five stalk stand the barren bred ears showed an increase of 0.96 and $1.12 \%$ respectively. Comparing the good ear with the barren bred ones the differences in barrenness are all greater in case of the barren bred seed ranging $12.86 \%, 25.21 \%, 32.41 \%$ and $31.95 \%$ as the stand ranged from two to five stalks per hill respectively. The last three differences are very constant and must be due to seed as the stand and soll were the same in each case. The differences also give a good idea of the percentage of barrenness inherited. No explanation can be offered as to why the first difference fell so low other than the stand in this case was nearly as large as in rows where it should have been greater thus making this row appear to have thrown a much greater percent of barren stalks than the thickness of the stand would watrant.

BARRERIESS DUE TO INCREASE OF STAND.

From Tables VII and VIII it will be seen that the number and percent of barren stalks for each class of seed increased directly with the stand. Since the increase was so 

uniform it shows that these was no difference in the fertility of the.soil over the whole plot: A very slight decrease occurred in the percent of barrenness of barren bred ears planted to four stalks per hill over three stalks and a considerable decrease in the same place in case of the good ear. This lotter case is accounted for by the fact that this row was badly washed and the number of stalks reaching maturity was only-27 as compared, to 34 plented to three stalks per hill. The first case is unaccounted for.

The last column in Table VII shows the ratio of increase in barrenness per stalk increase in stand. This ratio is very constant for the barren bred and naturally crossed ears, but exceedingly variable for the good ear. Since, however, these rows were badly damaged by the rains and wahing and since it did not come to a proper development the number of barren stalks produced may be considered too high and erratio. The average ratio of increase in barrenness per stalk increase in stand is 1:.76. In 1909 the average rat10 of increase was $1: .58$. These figures are constant each year and close enough to say that barrenness increases in direct ratio with the increase of stand and in ratio near $1: .58-.76$. These flgures may vary with another season. 



\section{UNITED STATES DEPARTMENT OF AGRICULTURE, \\ BUREAU OF PLANT INDUSTRY, \\ COOPERATING WITH \\ MISSOURI AGRICULTURAL EXPERIMENT STATION.}

SEED LABORATORY,

WISSOURI BRANCH.

Columbia, Mo., May 9, 1910.

Mr. F. H. Demaree,

city.

FINAL REPORT OF GERMINATION TEST OF SEED RECEIVED _.MQY-2,

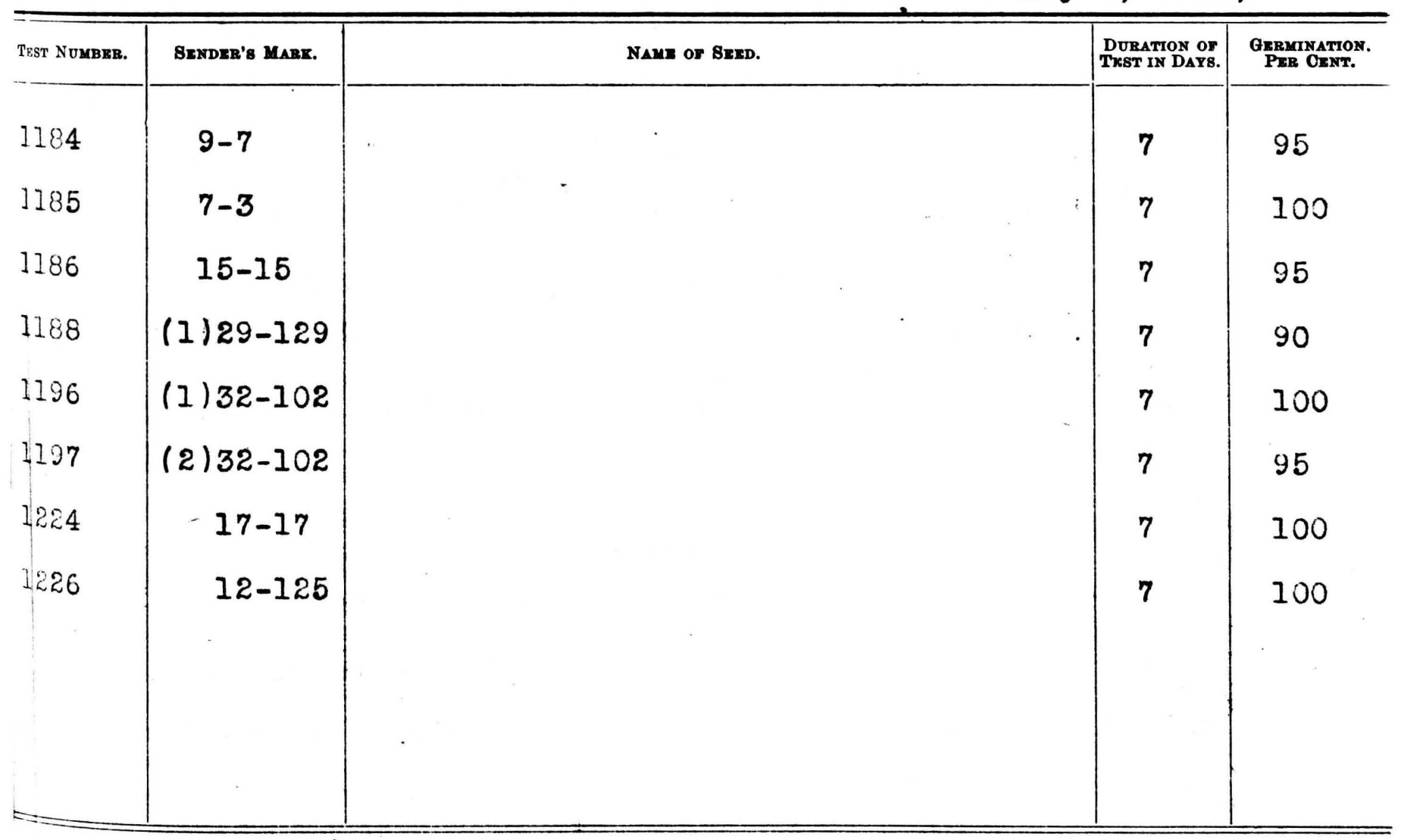

REMARKs Ears us in Barren work season 1910.

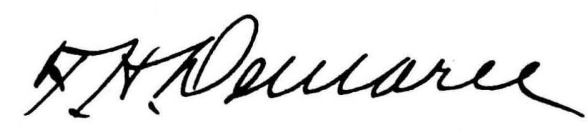

Collaborator in Charfo.

\footnotetext{
The names of the United states Department of Agriculture and of the Missouri Agricnitural Mxperiment slation mnst not be used for
} advertialng purposes in corrnection with this repmin. 

INCREASES IN STAND AS AFFECTING STALK CHARACIERISTICS.

Practically the same notes with the same results were secured on stalk characteristics due to changing the stand. Thickness of planting invariably decreases the vigor of the stalk, the size and drodp of the ear and increases the number and percent of broken stalks. It is well to note in this connection that the stalks from the barren bred ears were equaliy as vigorous as the others. Furthermore the power of germination of the seed before planting was equally as good as shown by the report on germination here prescnted. It does not seem then that barren pollen has any tendency to lessen the stalk vigor of the plants produced but a constitutional inability to produce an ear seems to be transmitted.

\section{INBREEDING AS AFFECTING BARRENHESS.}

Table IX shows the total percent. of barren stalks thrown by each barren bred ear of 1910. It will be noted that the two inbred ears 12-25 and 17-17 threw a larger percent of barren stalks in every case except 7-3 and 15-15 planted to two stalks per hill and $7-3$ planted to four stalks per hill. The average difference between the two classes for two stalks per hill 1o-6.86\%, for three stalks $24.92 \%$, for four stalks 1/61\%, for five stalks $26.62 \%$, This seems to show that inbreeding decreases the ear producing power of thestalks al though the table (V) on stalk character does not show the se rows to be poorer than the others.

Table $X$ shows the resul ts secured from the cross between 

TABLE IX.(1910).

SHOWING THE INFLUENCE OF INBREEDING. ALI E RS TERE HAND POLIINATED FROM BARREN STALKS. EARS 12-25 AND 17-17 WERE INBRED.

\begin{tabular}{|c|c|c|c|c|c|}
\hline $\operatorname{stand}$ & $\begin{array}{l}\text { Ear } 9-7 \\
\% \text { barren }\end{array}$ & $\begin{array}{l}\text { Bar } 7-3 \\
\% \text { barren }\end{array}$ & $\begin{array}{l}\text { Ear } 15-15 \\
\% \text { barren }\end{array}$ & $\begin{array}{c}\text { Ear } 12-25 \\
\text { Inbred } \\
\% \text { barren } \\
\end{array}$ & $\begin{array}{l}\text { Eer } 17-17 \\
\text { Inbred } \\
\text { \% barren }\end{array}$ \\
\hline $\begin{array}{l}2 \\
\text { talks }\end{array}$ & 15.15 & 38.24 & 50.0 & 37.5 & 17.7 \\
\hline $\begin{array}{l}3 \\
\text { Stalks }\end{array}$ & 20.75 & 40.0 & 61.67 & 78.12 & 66.67 \\
\hline 5 & 43.1 & 62.5 & 45.16 & 52.17 & 51.56 \\
\hline 5 talks & 47.95 & 55.7 & 64.06 & 81.27 & 83.78 \\
\hline $\begin{array}{l}\text { Aver- } \\
\text { sie. }\end{array}$ & 31.74 & 49.11 & 55.22 & 62.26 & 54.92 \\
\hline
\end{tabular}

\begin{tabular}{|c|c|c|c|}
\hline tand. & $\begin{array}{l}\text { Barren } \\
\text { cross bred. }\end{array}$ & $\begin{array}{l}\text { Barren } \\
\text { inbred. }\end{array}$ & $\begin{array}{l}\text { Difference favor } \\
\text { inbred. }\end{array}$ \\
\hline $\begin{array}{lc}2 & \text { stalks } \\
3 & \text { " } \\
4 & " \\
5 & "\end{array}$ & $\begin{array}{l}34.46 \\
47.47 \\
50.25 \\
55.9\end{array}$ & $\begin{array}{l}27.6 \\
72.39 \\
51.86 \\
82.52\end{array}$ & $\begin{array}{r}-6.86 \\
24.92 \\
1.61 \\
26.62\end{array}$ \\
\hline
\end{tabular}



TABIE X. (1910)

SHOWING THE EFFECT OF INBREEDING ON BARRENNESS

ANID YIRLD.

\begin{tabular}{|c|c|c|c|c|c|c|c|c|c|}
\hline Row & $\begin{array}{l}\text { Inbred } \\
\text { or cross }\end{array}$ & $\begin{array}{l}\text { No. } \\
\text { stalks }\end{array}$ & $\begin{array}{l}\text { No. } \\
\text { barren }\end{array}$ & $\begin{array}{l}\% \\
\text { barren }\end{array}$ & $\begin{array}{l}\text { No. } \\
\text { good }\end{array}$ & ears & $\begin{array}{l}\text { No. } \\
\text { nubbins }\end{array}$ & $\begin{array}{l}\text { Total } \\
\text {. wt.corn }\end{array}$ & $\begin{array}{l}\text { Total wt. } \\
\text { fod der }\end{array}$ \\
\hline 1 & inbred & 66 & 34 & 51.5 & $\because$ & $7:$ & 25 & 10 & 14 \\
\hline 2 & cross & 95 & 5 & 5.2 & & 43 & 47 & $4 I$ & 21 \\
\hline 3 & Inbred & 83 & 31 & 37.3 & & 8 & 44 & 17 & 25 \\
\hline 4 & cross & 88 & 8 & 9.09 & & 35 & 45 & 31 & 20 \\
\hline 5 & inbred & 68 & 20 & 29.4 & & 11 & 37 & 18 & 15 \\
\hline 6 & cross & 80 & 10 & \pm 2.5 & & 20 & 50)$. & 31 & 21 \\
\hline 7 & inbred & 59 & 26 & 44.1 & & 8 & 25 & 14 & 13 \\
\hline 8 & cross & 86 & 29 & 33.7 & & 13 & 44 & 21 & 17 \\
\hline 91 & cross & 75 & 15 & 20.0 & & 9 & 51 & 21 & 15 \\
\hline 10 & inbred & 59 & 26 & 44.1 & & 10 & 23 & 11 & 19 \\
\hline Av. & inbred & 67 & 27.4 & 40.9 & & 8.8. & 30.8 & 14, & 17.2 \\
\hline Av. & cross & 84.8 & 13.4 & 15.8 & & 24 & 47.2 & 29 & 18.8 \\
\hline $\begin{array}{l}\text { Dif: } \\
r \in f- \\
\text { erir } \\
\text { to }\end{array}$ & inbred & -17.8 & +14.0 & +25.1 & & -15.2 & -16.4 & -15 & -1.6 \\
\hline
\end{tabular}



$10 \times 67$ and the inbred 10. Five rows were planted to the cross and five to the inbred seed. The cross was detasseat and the inbred furnished the pollen. During the season the inbred rows seemed the more growthy but at harvesting time the yields with the number of barran stalks produced did not thow up. The averages for the two show $25.0 \%$ more barren stalks in the inbred rows. While the cross produced 15 more good ears, 16 more nubbins, 15 more pounds of corn on the average and an average of 1.6 pound more fodder per row. The stand in each case started the same. At the end however, more of the cross bred stalks came to maturity thus indicating superior vitality of stalk in this case. It is decidedly evident however, that the inbred plents did not ear as well nor produce as large ears as the cross bred ones.

\section{DESCRIPTIONS OF BARREN STALKS.}

In the fall of 1908 while doing some work on individual stalks, the writer found one of the few absolutely barren stalks which occur even under favorable conditions in most fields of corn.

This stalk (No. 148) was nine feet high, seemingly very vigorous and had fifteen leaves. The leaves were lonf, medium in width, and light green in color. The stalk was practically mature at the time it wes found but the upper nine leaves were standing almost straight out. The leaves and sheathes 

The stalk upon disection proved to be practically round, at the second node above ground were some rudimentary brace roots and on the third and fourth nodes appeared small rudimentary shoots. These were less than one inch in length and 1/40 of inch in width and as thin as tissue paper. From the four th node the stalk begame perfectly round with no sign of a shoot. The color of the leaf,sheathes and stalk was a reddith-yellow. The nodes were strong but not pronounced and the whole stalk tapered from the base to the tassel.

The tassel was large, branches thick and outstanding. This stalk was found growing in hill with another stalk on good soil. The stalk by which it was growing was of about the same height, vigorous, flatter than the barren stalk having a groove running between nodes on alternate sides of the stalk as is characteristic of corn. It produced a good ear.

During the same season the writer found a barren stajk in the variety test of Johnson County wite and one of Boone County White. The leaves of the Johnsom: County White stalk were rather narrow and long having fleshy sheathes. They had the same peculiar outstanding posture of stalk 148 . The stalk itself was $7 \mathrm{I} / 2$ feet high, slender and nearly round but with nodes fairly well pronounoed. It had four rudimentary shoots but no kernels were formed.

The tassel was heavy, thiok, each branch being heaply Iaden with empty pollien cases. There was a long main 

spike also derisely covered with cases.

The Boone County Wite stalk was $71 / 2$ feet high, larger and flatter than the Johnson: County White one.k. The nodes were thirteen in number but not so well pronounced as in the other. The leaves were much the same in shape and posture as has been described.

There was no sign of a shoot from the outside but upon examination nine small shoots were found ranging from the first node up. The last one had some husks over a rudimentary cob but no embryos nor silks were formed.

\section{DESCRIPTIONS OF BARREN STAIKS. (PIot of 1909).}

Barren Stalk No. 3. This stalk was 8 feet 6 inches high and $21 / 2$ inches in circumference at the second node. The stalk was very slender and the internodes long. It possessed thirteen nodes, fairly well pronounded. The leaf, sheathes and leaves were vairly fleshy and had a great deal of red color in them. There was a well developed shoot on the stalk but no grain was formed. The tassel was amall and sparsely branched. Stalk No. 7 .

This stalk was 9 feet tall $23 / .4$ inches in circumference at the second node. The internodes were fairly long with notes that well pronounced. The nodes were fourteen in number. The leaves were fairly fleshy and outstanding. The sheathes were also fleshy and there was considerable red color in stalk,sheathes, and leaves. This stalk also had put out several small shoots but no grain was formed. The tassel was 

large with a long main spike. Stalk Ho. 8.

This stalk was 8 feet, 2 inches tall and $21 / 2$ inches in circumference at the second node. The internodes were fairly long and the nodes well pronounced. The nodes were twelve in number. The leaves were thin and the sheathes fleshy with red color in both sheathe and stalk. The tassel was heavy and compact with a lerge main sipke. Stalk No. 10.

This stalk was 9 feet, 6 inches high, $21 / 2$ inehes in circumference at the second node. It possessed thirteen nodes, medium in size with long internodes. The leaves and sheathes were fleshy and showed a red color. There was a very small shoot but no grain had formed. The tassel was medium in size with a long main spike. Stalk No. 11. and 6 inches high, This stalk was 10 feet/ $27 / 8$ inches in circumference at the second node. The nodes were fourteen in number and well pronounced. The internodes were fairly long. The leaves were thin but the sheathes were fairly fleshy. Tho: red color was shown in the stalk. There was a rell developed shoot and embryonic cob but no grain. The tassel was very heavy and thick. Stalk No. 15.

This stalk was 11 feet 6 inches high and $23 / 4$ incies in circumference at the second node; It had fourteen nodes which were not pronounced. The internodes were very long. The 

leaves and sheathes were fleshy and the stalk showed considerable red color. -Several shoots were produced but no grain.

The tassel was medium in size and very compact and had a large main spike. Stalk No. 16.

This stalk was 11 feet high and 3 -inches in circumference at the sedond node. The nodes were sixteen in number and only feirly pronounced. The internodes were medium long and the leaves and sheathes were tleshy. Some red color was show in the stalk, leaves, and sheathes. Small shoots were produced but no grain. The tessel was very smell but very compact. Stalk No. 17.

This stalk was 11 feet 6 inches high and 3 inches in circumference at the second node. The nodes were fifteen in number and not pronounced. The internodes were only fairly long. The leaves and sheathes were still green in color turning to a reddish-jellow. They were also very fleshy. This stalk had fairly well developed shoots but no grain. The tassel was large and branching with a large main spike. Stalk No. 20.

This stalk was 11 feet tall and $31 / 3$ inches in circumference at the second node. It had sixteen nodes which were well pronounced. The internodes were long. The leaves were fairly thin and the sheathes were fleshy. The red color was shown in stalk, sheathes and leaves. There were four 

well developed shoots on this stalk but not a kernel had tormed. The tassel was large and brenching. Stalk No. 22.

This stalk was 8 feet 6 inches high, $21 / 4$ inehes in circumference at the second node. It had thirteen nodes, which were fairly well pronounced. The internodes were long. The leaves were thin but the sheathes were fleshy.' The red color was shown in both sheathes and stalk. The stalk produced two small shoots but no grain. The tassel was small but had a large main spike. Stalk No. 23.

This stalk was 10 feet high $23 / 4$ inches in circumference at the second node. It had fifteen nodes and the nodes were of medium size. The internodes were of medium length. The leaves and sheathes were fleshy and had a great deal of red bollor in both. There were several shoots one of which produced/embryonic cob but no grain. The tassel was medium in size and widely branching. Stgik No. 25.

This stalkwas 10 feet 3 inches high, $23 / 4$ inches in circumference at the second node. There were thirteen nodes which were not well pronounced. The internodes were long and slender. The leaves and sheathes were fleshy and the leaves upstanding. The sheathes possessed a great deal of red color. The tassel was large and branching with a heavy main spike. 

seems that we can rightly infer that a typical barren stalk is rather round, the noder not pronounced, generally long and slender with leaves and sheathes fleshy bausing the leaves to have a pecullar upstanding appearance. When mature the leaves and sheathes ate sometimes the stalk, possess a peculiar red color. It 1o well to add that in every case the stalk is much heavier than a good stalk of corn and is full of sugar.

The appearance of good stalks of corn is much different from the above description. A productive stalk is generally flat instead of round. It is also grooved deeply on alternate sides between nodes. In these grooves the shoots come. The leaves and sheathes are elso generally thin and generally turn a whitish yellow upon ripening rather than redish. The stalk also bocomes pithy and does not remain solid as did the barren stalks. This is probably due to the fact that the food found in the various parts of good stalks is transferred to the ear while in the case of barren stalks this remained deposited in the various parts of the staik. The following table shows the velght of stalk, leaves, sheathes and grain of various barren and good stalks of corn. 

TEBIE XI.

SHOWING TEIGHT OF IIAVES, SHEATHES, STALK OF BARPEN AID PRODUCTIVE STALKS OF CORN.

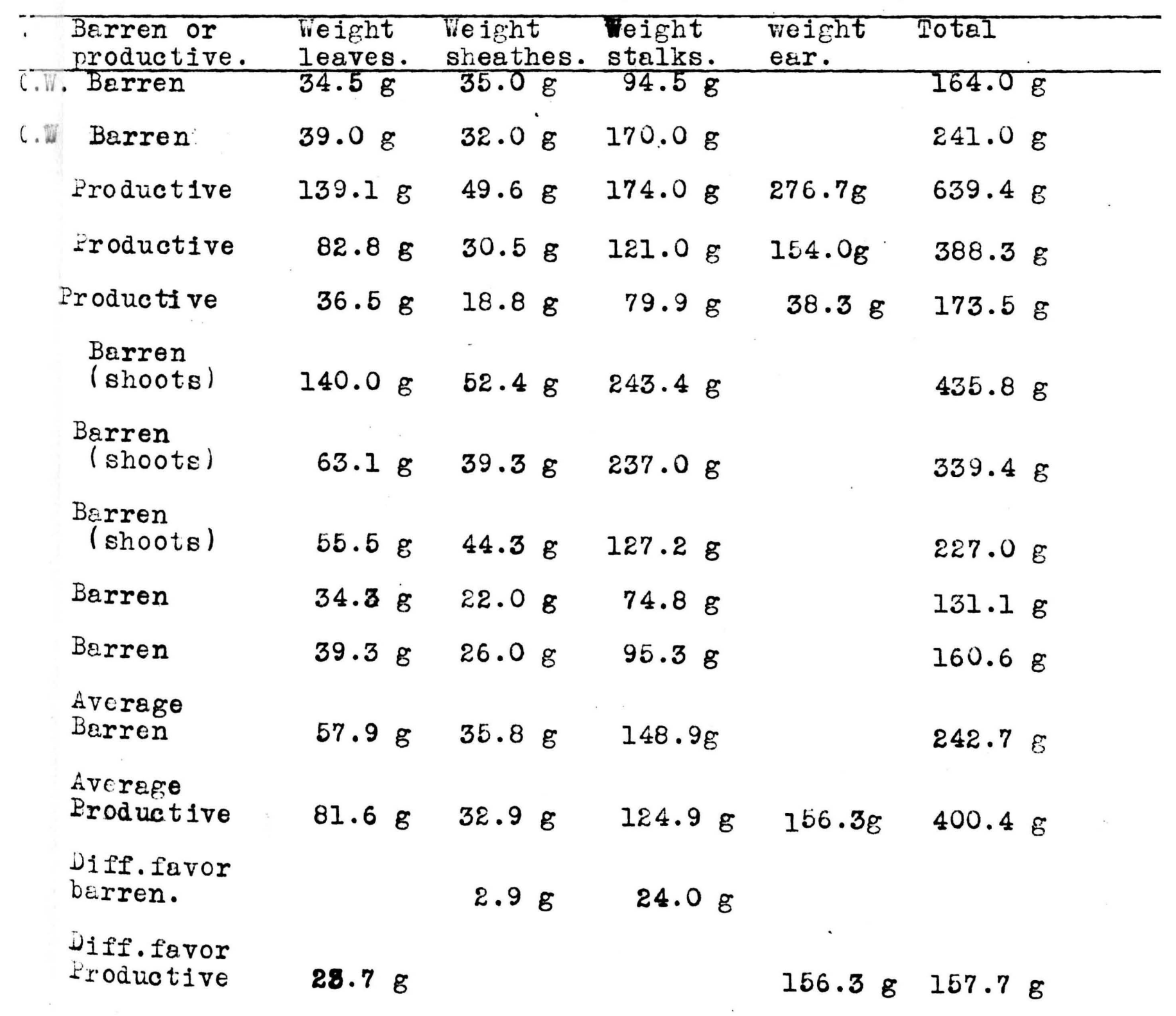



From the table it will be seen that the average weight of the barren stalks studied never equalled the total weight including the ear of fertile stalks. The differences in weight of ear then, is always in favor of productive stalks. There was a difference of 24 grams in weight of stalk in favor of the barren stalks and also 2.9 grams in weight of leaf sheathes in favor of the barren stalks. The actual weight of the leaves themselves however, was greater in the casc of the productive stalks there being on the average 23.7 grams more weight in the favor of the leaves from the fertile stalks. The question now naturally arises, what becomes of the plant food eleborated by the batren stalks since they produce no grain. Those stalks number from 1 to 8 inclusively were analyzed in order to determine the percentage of various plant foods found in each division of the stalks noted. The ears of the productive stalks were not analyzed because there was no corresponding part to compare them with in case of the barren stalks. The following table shows the results of this snalysis. 

TABLE XII

ANALYSIS OF CORN STALKS--BARREN AND PRODUCTIVE.

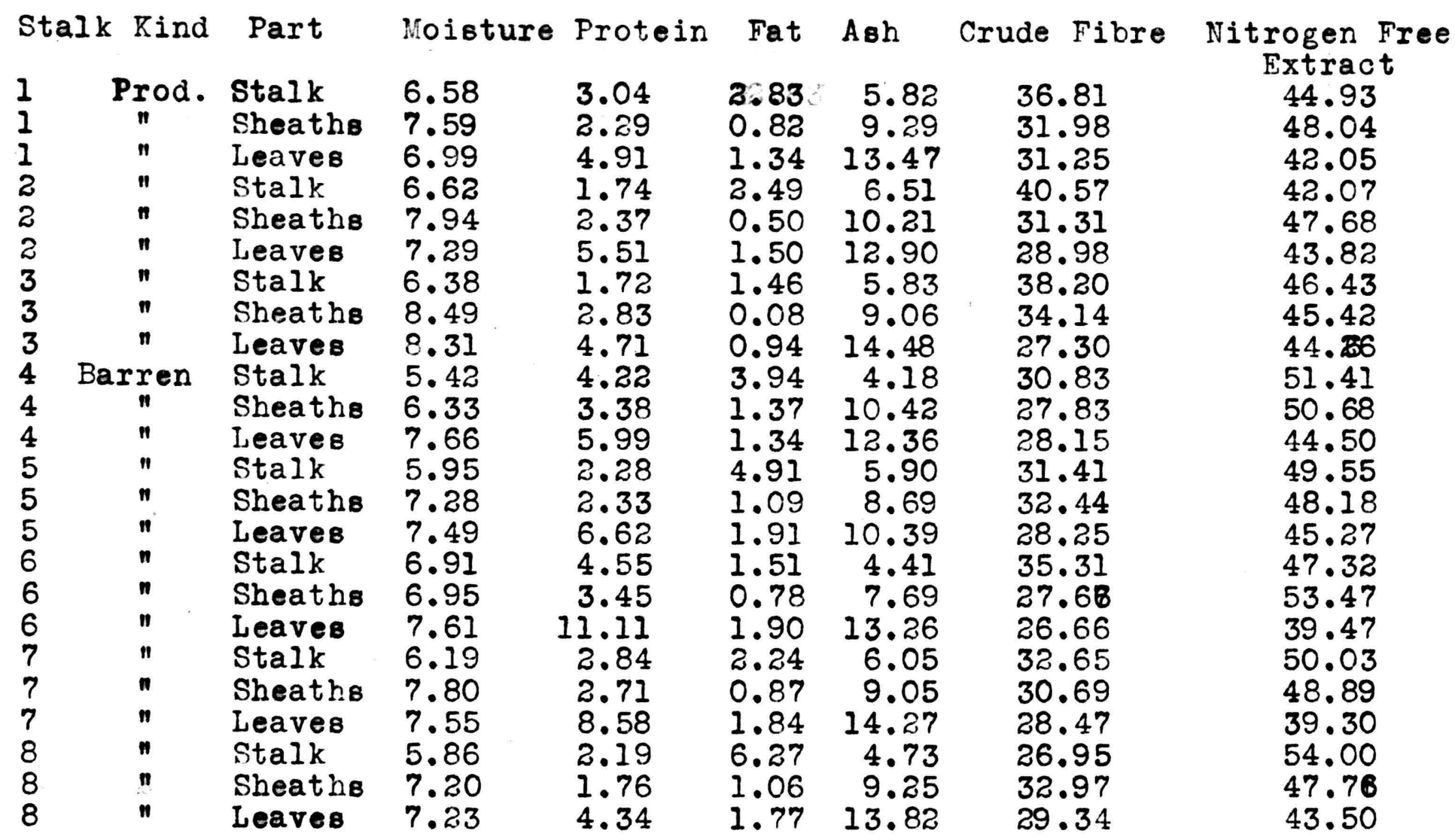



TABLE XIII

Showing Average Analysis of Barren and Productive Stalks of Corn with the Location of Plant Food.

\begin{tabular}{|c|c|c|c|c|c|c|c|}
\hline Character & Part & Moisture & Protein & Fat & $\mathrm{Ash}$ & $\begin{array}{l}\text { Cruade } \\
\text { Fibre }\end{array}$ & $\begin{array}{l}\text { Nitrogen Free } \\
\text { Extract }\end{array}$ \\
\hline $\begin{array}{l}\text { Prod't } \\
\text { Barren } \\
\text { Diff.Prod. } \\
\text { or Barren }\end{array}$ & stalk & $\begin{array}{l}6.53 \\
6.07 \\
0.46\end{array}$ & $\begin{array}{l}2.17 \\
3.22 \\
1.05\end{array}$ & $\begin{array}{l}2.26 \\
3.77 \\
1.51\end{array}$ & $\begin{array}{l}6.05 \\
5.05 \\
1.00\end{array}$ & $\begin{array}{r}38.53 \\
31.23 \\
7.30\end{array}$ & $\begin{array}{r}44.48 \\
50.26 \\
5.78\end{array}$ \\
\hline $\begin{array}{l}\text { Prod't } \\
\text { Barren } \\
\text { Diff.Prod. } \\
\text { or Barren }\end{array}$ & Sheaths & $\begin{array}{l}8.07 \\
7.11 \\
0.96\end{array}$ & $\begin{array}{l}2.50 \\
2.73 \\
0.23\end{array}$ & $\begin{array}{l}0.47 \\
1.03 \\
0.56\end{array}$ & $\begin{array}{l}9.52 \\
9.02 \\
0.50\end{array}$ & $\begin{array}{r}32.48 \\
30.32 \\
2.16\end{array}$ & $\begin{array}{r}47.05 \\
4 y .80 \\
2.75\end{array}$ \\
\hline $\begin{array}{l}\text { Prod't } \\
\text { Barren } \\
\text { Diff. Prod. } \\
\text { or Barren }\end{array}$ & Leaves $_{n}$ & $\begin{array}{l}7.53 \\
7.51 \\
0.02\end{array}$ & $\begin{array}{l}5.04 \\
7.34 \\
2.30\end{array}$ & $\begin{array}{l}1.26 \\
1.75 \\
0.49\end{array}$ & $\begin{array}{r}13.52 \\
12.82 \\
0.80\end{array}$ & $\begin{array}{r}2 y .18 \\
28.17 \\
1.01\end{array}$ & $\begin{array}{r}43.38 \\
42.41 \\
0.97\end{array}$ \\
\hline
\end{tabular}



Table XIII is a summary of the previous one. It shows the average composition of the three parts of productive and barren stalks analyzed.

The differences in composition of the various parts are interesting. The productive stalks, sheaths, and leaves contained more moisture, ash, and crude fibre than did the barren stalks. On the other hand the stalks, sheaths, and leaves of barren stalks contained more protein, fat, and nitrogen free extract than did those of productive stalks.

This analysis bears out the observation made that barren stalks seem to be full of sugar, and leaves and sheaths fleshier than productive ones. The difference in composition is not enough however to say that all of the food which would go into the ear is lodged in some part of the plant. It would seem then that barren stalks do not manufacture food much beyond their own needs. since then this function of the plant largely ceases upon maturity of the plant it is another evidence that true barrenness is an inherent tendency and not a condition induced by circumstance. 



\section{DATA ON BARREIINESS FROM OTHER SOURCES.}

\section{Barrenness in Corn Varieties.}

Table XIV s shows the total number of stalks, the number of barren stalks, percent of barren stalks, and jield per acre of the varieties of corn grown on the Expericent Station field at the University of Missouri in the season of 1910. It will be noted that the percent ol barrenness var ies from 1,01 to 9.2. The $101 \%$ was a check which was Boone county White and the $9.2 \%$ was St. Charles White. Owing to the fact that our soil is rather ununiform all our varieties of grain are planted with a check of some good variety introduced every third plot. In case of these corn varieties every variety vas planted in a long row each row being 3 feet, 4 inches apart and the hills 3 feet, 4 inches in the row. The stand was thinned to two stelks per hill when the corn was about 6 inches high. By following the percentage of varrenness in the two checks which inslose each set of two varieties it can be seen whether or not the varrenness was due to poor soil or was a varietal charecteristic. If due to poorer soil the percentage of varrenness in the checks should be large as well as the pereentage of barrenness of the varieties. Special instances are noted as in the case of st. Charles White wich produced $9.2 \%$ of barren stalks and commercial Vinite growing by the side of it produced $11.11 \%$ of barren stalks while the two che cks of Boone County White on each side of these rows produced $5.78 \%$ and 5.93\% of barren stalks. Another instance is in the cuse of the Cartner which produced only $2.03 \%$ of barren stalks as compared 

with $7.47 \%$ of barren stalks produced by the check which grew in the row beside it. Such tendencies to throw a number or very fev barren stalks si nce they vary so far a bove in the one case or below the check in the other, must be due to an inherent characterist1c of the variety rather than an external influence. This seems espectally reasonable when we cunsider that the rows were side by side, the stand was the same, the season, oultivation and any other factors which would have entered were also the same.

The average yield of the five varieties producing the highest percent of barren stalks was 58.5 bushels per acre. The average yield of the five varieties throwing the lowest percent of barren stalks was 65.1 bushels per acre. This leaves 6.6 bushels per acre in favor ol those varicties producing a low number of barren stalks. The difierence in percentage of barrenness between the two was $5.74 \%$. It must be remembered in this connection that there is a great deal of difference between the jields of various varieties of corn due to adaptability and yielding power, so that there is a chance that this difference in yield is due as much to the variety characteristics as to the barren tendency. However, since the two points under discussion are in such close correlation that it is a very important piece of evidence that barrenness may be a variety characteristic and tends to decrease the yield oit those varieties. 

TABLE XIV.

3HOTING BARRENNESS OF VARIETIES OF CORN UNDER TEST AT

THE MISSOURI EXPERIMENT STATION. SEASON 1910.

\begin{tabular}{|c|c|c|c|c|}
\hline \multirow[t]{2}{*}{ Variety } & $\begin{array}{l}\text { Total } \\
\text { stalks }\end{array}$ & $\begin{array}{c}\text { No. Barren } \\
\text { stellks }\end{array}$ & \multirow{2}{*}{$\begin{array}{r}\begin{array}{r}\% \text { Barren } \\
\text { stalks }\end{array} \\
2.17\end{array}$} & \multirow{2}{*}{$\begin{array}{c}\begin{array}{c}\text { Yield Bu. } \\
\text { per Acre }\end{array} \\
47.43\end{array}$} \\
\hline & 414 & 9 & & \\
\hline Hogues Yel. Dent & 382 & 20 & 5.23 & 63.86 \\
\hline Reids Yel. Dent & 372 & 9 & 2.41 & 78.43 \\
\hline Check & 374 & 14 & 3.74 & 68.68 \\
\hline Leaming & 386 & 72 & 3.10 & 61.57 \\
\hline Cartner & 393 & 8 & 2.03 & 62.77 \\
\hline Check & 360 & 27 & 7.47 & 72.99 \\
\hline St. Chas. YeI. & 374 & 13 & 3.47 & $62.05^{\circ}$ \\
\hline Hilareths Y. D. & 469 & 27 & 5.75 & 91.23 \\
\hline Check & 437 & & & 78.23 \\
\hline Eclipse & 392 & 17 & 4.33 & 52.51 \\
\hline Priae of North & 260 & 21 & 8.07 & 28.19 \\
\hline Chects & 430 & 17 & 3.95 & 88.08 \\
\hline Pride of Nishua & 377 & & & 47.57 \\
\hline Queen of Nishua & 388 & 13 & 3.35 & 40.13 \\
\hline Check & 377 & 10 & 2.65 & 81.00 \\
\hline Fartiers Reliance & 316 & 18 & 5.69 & 30.93 \\
\hline Boone co. White & 421 & 29 & 6.88 & 66.02 \\
\hline Cheok & 380 & 22 & 5.78 & 68.68 \\
\hline St. Chas. White & 384 & 35 & 9.20 & 65.75 \\
\hline Commercial Thite & 447 & 50 & 11.11 & 82.30 \\
\hline $\begin{array}{l}\text { Cheok } \\
\text { lot }\end{array}$ & 421 & 24 & 5.93 & 68.37 \\
\hline Johnson Co. W. & 360 & 17 & 4.72 & 55.48 \\
\hline $\begin{array}{l}\text { Clay Co. White } \\
\text { Check }\end{array}$ & 389 & 33 & 8.48 & 62.80 \\
\hline $\begin{array}{l}\text { Check } \\
\text { Diamond }\end{array}$ & 418 & 17 & 4.06 & $\begin{array}{r}72.69 \\
2.36\end{array}$ \\
\hline $\begin{array}{l}\text { Diamond Joe. } \\
\text { Champion W. P. }\end{array}$ & $\begin{array}{l}367 \\
364\end{array}$ & $\begin{array}{l}19 \\
18\end{array}$ & $\begin{array}{l}5.17 \\
4.94\end{array}$ & $\begin{array}{l}62.36 \\
63.75\end{array}$ \\
\hline Check & 373 & 18 & $\begin{array}{l}4.82 \\
4.82\end{array}$ & 67.75 \\
\hline Silvermine (Ia.) & 358 & 19 & 5.30 & 56.45 \\
\hline Silvermine (III) & 379 & 22 & 5.80 & 53.67 \\
\hline $\begin{array}{l}\text { Check } \\
\text { Cob Pine }\end{array}$ & $\begin{array}{l}356 \\
340\end{array}$ & $\begin{array}{r}14 \\
9\end{array}$ & $\begin{array}{l}3.93 \\
0.62\end{array}$ & $\begin{array}{l}67.76 \\
82.24\end{array}$ \\
\hline $\begin{array}{l}\text { Sob Pipe } \\
\text { Strain } 4\end{array}$ & $\begin{array}{l}342 \\
338\end{array}$ & $\begin{array}{r}9 \\
19\end{array}$ & $\begin{array}{l}2.62 \\
5.62\end{array}$ & 58.75 \\
\hline Check & 423 & 38 & 8.98 & \\
\hline Lenochers Hm'sta & 344 & 18 & 5.23 & 51.02 \\
\hline Calico & 343 & 14 & 4.08 & 65.46 \\
\hline Bloody Butcher & 414 & 37 & 8.93 & 84.25 \\
\hline & & & & \\
\hline
\end{tabular}



TABIE XV. .

SHOWING BARRENMESS IN BOONE COUNTY WHITE BREEDING

EARS OF CORN. SEASONS OF 1970 AND 1971.

Ear No. Total No. \%- Yield. Ear No. Total No. \%- Yield.

Check

Check

$10-1$

$10-2$

Cheok

$10-3$

$10-4$

Check

10-5

10-6

Check

10-7

$10-8$

Check

10-9

$10-10$

Check

10

67

Check

$67-2$

$67-3$

Check

67-6

70-1

Cheok

$70-3$

$70-4$

Check

$70-5$

45-3

Check

45-4

61-2

Check

6I-4

$6 I-5$

Check

6I-6

$48-1$

Check

$48-2$

$48-4$

Check

$58-4$ stalks Barren Barren

(1)

stalks Barren Barren

-

- Cheok 127 I

$141 \quad 1$

$3.5754 .6,33-1 \quad 141$

$5.98 \quad 54.6 \quad 33-2 \quad 146$

Check 125

$2.63 \quad 47.8 \quad 33-3 \quad 140$

$10.35 \quad 45.5 \quad 45-4 \quad 137$

Cheok 137

$\begin{array}{llll}4.63 & 46.9 & 31-2 & 149\end{array}$

$0.9260 .6 \quad 31-3 \quad 140$

Check 116

$3.63 \quad 52.9 \quad 31-4 \quad 139$

$2.75 \quad 52.9 \quad 31-5 \quad 136$

Check 125

$3.84 \quad 63.9 \quad 31-6 \quad 143$

$0.9365 .8 \quad 31-7 \quad 137$

Check 128

$\begin{array}{llll}0.99 & 39.9 & 45-3 & 138\end{array}$

$0,87 \quad 58,0 \quad 28-3, \quad 131$

1151

1142

$118 \quad 1$

$\begin{array}{llll}1.75 & 55.5 & 54-2 & 141\end{array}$

0.848

58.0

69-1

Check II3

$\begin{array}{llll}1.69 & 50.8 & 7-2 & 135\end{array}$

3.39

$60.170-6$

Cheok

139

$2.54 \quad 53.3 \quad 10-2$

1.75

$48.14-1$

Check

$0.909 \quad 53.5 \quad 4-2$

0.86

$67.4 \quad 19-2$

$0.86 \quad 69.2 \quad 13-1 \quad 114$

$0.0 \quad 59.9 \quad 13-2$

Check 124

$1.7261 .6 \quad 13-3 \quad 141$

1.83

$51.0 \quad 10-8$

Check 135

$2.250 .516-1, \quad 129$

$0.917 \quad 56.8 \quad 16-2$

Cheok 130

$4.25 \quad 47.9 \quad 16-3 \quad 144$

$1.060 .1 \quad 10-10 \quad 126$

$100 i$

$\begin{array}{rr}60 & 1 \\ 112 & 2\end{array}$

$\begin{array}{lll}1.67 & 30.4 \text { Check } & 131 \\ 1.79 & 63.521-2 & 122 \\ & & 132\end{array}$

1
1
9
3
5
7
4
2
6
4
4
0
10
5
3
13
13

10

1 ?

5

5

2

8

3

4

6

9

5

3

8

6

7

7

1

6

4

1

1

1

2

6

7

4
3

3
$\mathbf{4}$
$0.787 \quad 62.37$

$0.71 \quad 89.20$

$6.16 \quad 91.36$

$2.40 \quad 54.75$

$3.57 \quad 80.16$

$5.11 \quad 75.02$

$2.92 \quad 67.97$

$1.34 \quad 92.84$

$4.29 \quad 108.85$

$3.45 \quad 50.03$

$2.88 \quad 102.10$

$0.0 \quad 96.30$

$8.0 \quad 58.53$

$3.5 \quad 93.50$

$2.19 \quad 101.65$

$10.2 \quad 61.67$

$7.24 \quad 92.42$

$0.76 \quad 106.16$

$3.97 \quad 65.30$

$3.55 \quad 84.44$

$1.45 \quad 83.49$

$7.08 \quad 60.77$

$2.22 \quad 73.61$

$2.88 \quad 106.00$

$4.92 \quad 63.49$

$6.62 \quad 85.98$

$3.42 \quad 94.87$

$2.86 \quad 58.95$

$2.65 \quad 71.83$

$4.69 \quad 68.10$

$5.47 \quad 70.74$

$6.14 \quad 61.70$

$0.7 \quad 96.60$

$4.84 \quad 74.37$

$2.84 \quad 85.69$

$0.72 \quad 81.64$

$0: 74 \quad 75.28$

$0.77 \quad 71.45$

$1.8 \quad 64.90$

$4.61 \quad 78.91$

$5.35 \cdot 76.70$

$3.17 \quad 59.74$

2.29 79.81

3.78 56.95 

TABIE XV. . COHTIIUED.

SHOWING BARRTNNRSS IN BOONE JOUNTY WHITE BREIDING

EARS OF CORH. SEASOHS OF 1910 AND 1911.

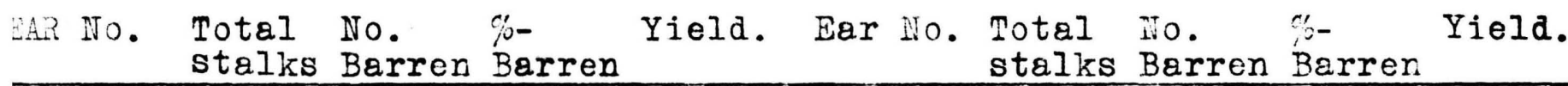

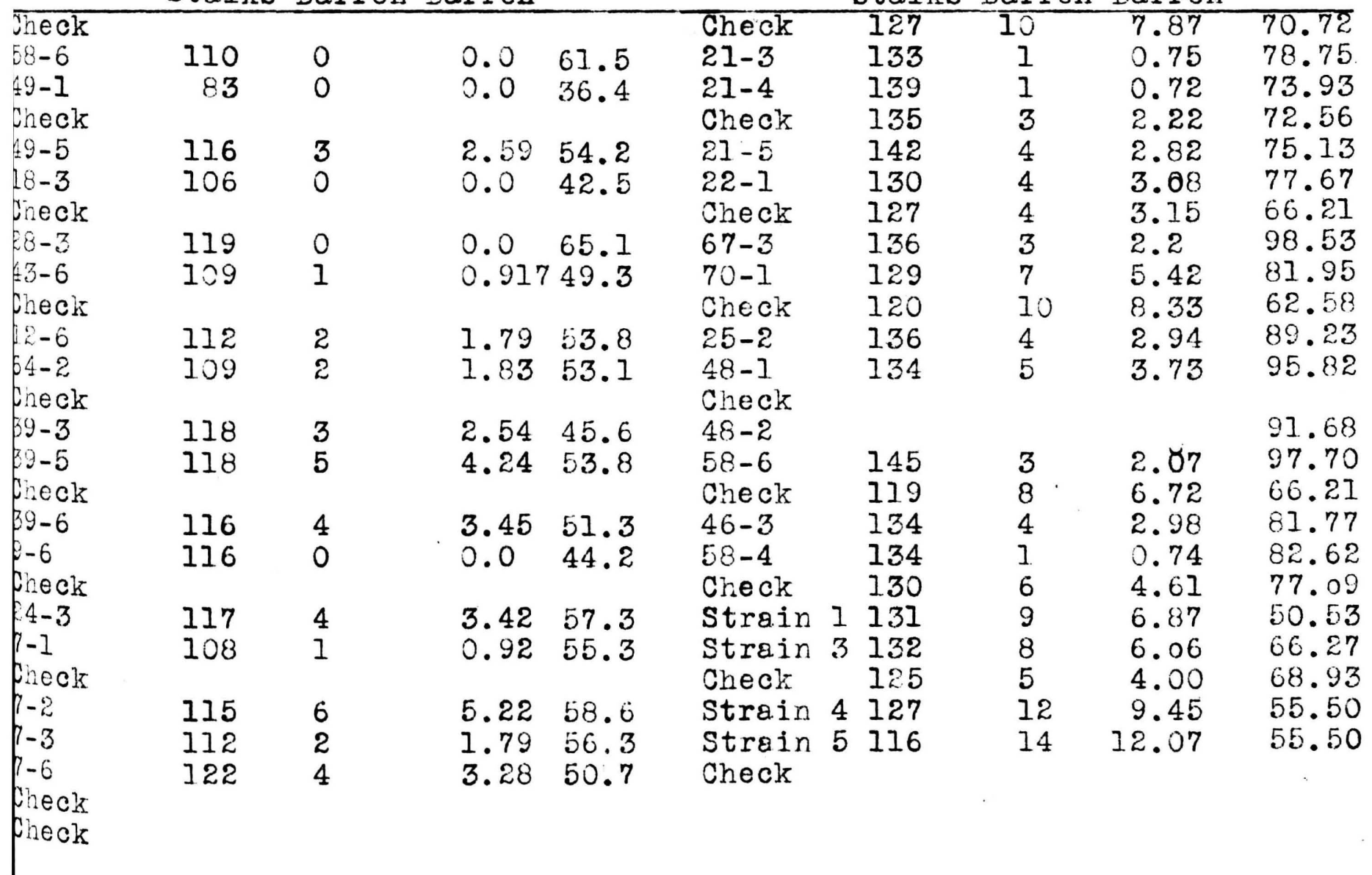





\section{Barrenness in Breeding Corn.}

Data has been secured on the various ears of the breeding corn plot of this institution for the past two years. The corn in question is of Boone County White variety and has been bred along the ear-to-row method since 1904. At that time a bushel of this corn was secured and the ears planted, an ear to a row. Several ears were selected every succeeding year from the highest producing rows and these in turn planted, each an ear to a row. At the present time all of the ears being bred came from three original ears - numbers 17, 22 and 30. The firt thing to note is that there is a wide range in the number of barren stalks produced by indiviaual ears. In 1909 ears $612,58-6,48-1$ and $9-6$ did not produce a barren stalk while ear 104 produced twelve. In 1910 ear 3 H5 did not produce $\&$ barren stalk while 453 produced ten. io data on the check rows was secured in 1009 but was taken in 1910. This check was unimproved Boone County White and it is to be noted that in many cases the number of barren stalks is comparatively high. Take the case of ear 317 and it will be seen that it produced only three barren stalks while the checks on each side produced ten and thirteen respectively. Now, since the checks were of the same corn it is probable that this high number of barren stalks is due to a strip of poor soil in that portion of the field. However, since $3 \mathbf{3} 7$ only produced three barren stalks this ear certainly had very little barren tendency.

The one thing which is striking in this study of 

and peroent of barren stalks produced. Unless this tendency was inherited from previous fertilization, why should not the number of barren stalks produced in the individual cases vary with the check rows which indicated the lertility of the soll over the whole plot?

\section{CONTEMPORARY DATA.}

No such experiment as the one dealt with in this thesis has ever been reported to the knowledge of the writer. Furthermore, there is very little said about barrenness with the exception that barren stalks are obviously a nuisance in \& field and should be eliminated. In bulletin 107 of the University of Ninneso ta the following statement is made concerning barrenness: "Barren stalks are those which bear no ears. They may be discovered by the absence of the enlarged leaf sheath just above the joint where the ear should appear. In average fields of corn in the state there are often $10 \%$ barren stalks - such features as physical weakness and barrenness tend toward deterioration and wust be avoided. If left to ripen the pollen from the se stalks fertilize the strong ones which may possibly be selected". The author evidently belleves that barrenness is anhereditary and transmissable charaoter.

In bulletin 91 of the Nebraska Experiment Station the following paragraphsappears: "A study of the results noted from the differences in rates of planting discovered that the percent of barren stalks 1 airectly affected by the rate of 

planting. Thus in $18046 \%$ of the stalks planted at the rete of one to the hill were barren while the rate ranged a high as $27 \%$ in the corn plented at the rate of five stalks $p \in r$ hill. Crowding is thus seen to result in a degree of barrenness higher than would otherwise be natural".

In bulletin 112 page 30 of the liebraska Station appears the results of an experiment on the rates of planting corn. The column devoted to barrenness shows three barren stalks per hundred when planted one stalk per hill and the number increases directly to 10.8 barren stalks per hundred when the stand was increased to five stalks per hill. This experiment is in agreement with the one previously noted and both of them are in perfect accord with the results on varied rates of planting shown in this thesis.

In bulletin 141 Bureau of Plent Industry, U.S.Department of Agriculture, is found the paper on "The Importence of Broad Breeding in Corn". In discussing the question of the removal of barren stalks the writer is of thejopinion that the tendency to barrenness is but an adaptation to prevent inbreeding. He in part, "This persistent tendency to proterandry can be thought of as a natural reaction of the species against the danger of extinction from inbreeding. Even the true bar ren stalks might represent a tendency on the part of the plant to become dioecious." This may give us another theory as to the true cau oe of barrenness. It may be an adaptation to prevent inbreeding and the truly barren stalks may be males which have been produced exclusively for the purpose of producing pollen. Even thought this be the case it 

is of economic importance to prevent barraness beceuse ot the decrease in the yield of corn which $\mathrm{vill} r$ esult fror breeding them. Bulletin 165 of the Virginia bxeriment Station, also contains a short summary on barrenness. The general conclusion presented hore is as follows: "Our work herc seems to reveal the fact that these barren stalks come chicfly Irom two sources; first, from stalks that have become distorted or injured in any wey as from a fungus growth which may weaken a plant and cause it to silk too late to receive the pollen, or it way be injured from cultivation and the same result will follow. Second, veak germination is apparently the cause of more barren stalks than an ything else, preventing as it does the development of the stalk in time to becone properly pollinated. Vigorous growing varieties that mature late or are not woll suited to the ection of the country in wich they are grown are likely to show a large percent of barren stalks." 

BARREIIISSS AND MENDEIISM.

Since the foregoing results prove conclusively that barrenness in corn is hereditary, the question which logically arises is in what way is this character trangmitted. Since a barren stalk produces no seed, goingon the old theortes of heredity we would naturaliy think that barrenness would bred 1tself out. In view of the fact that it does not, but on the contrary the number of barren stalks is made to increase, then we are foroed to admit that either our old 1deas of heredity are wrong or that our conclusions are not justifled. That the conclusions are justifiable is evident from the number of barren stalks produced from barren bred stalks as compared with good.

In order to explain the phenomenon let us consider the Mendelian theory. A kernel of oorn planted produces a stalk which in turn produces an ear. Suppose the embryo which formed this kernel had been fertilized by barren pollen. Aocording to the law of segregation this kernel when planted would have produced a shoot bearing approximately 1000 embryos and half of these embry0s would have been good and the other half barren. If barren pollen had been applied by hand it is obvious that the 500 embryos Which contain in themselves the barren tendenoy would have been fertilized by pollen grains which also contain barren tendency. Consequently, this set of kernels would have produced stalks the next year whioh were totally barren. The other 500 would be oross bred and in turn would aot as the original kernel. From this it oan be seon that taking barrenness as a Nendelian character, barren 

stalks can be produced and increased in number as well without the production of seed on the barren stalk. This explanation will nicely explain the differences in the number of barren stalks produced by various ears of corn.

\section{POSSIBILITIES IN CORN BREEDING.}

Once proven that barrenness follows Mendelian principles the fact would lead to a much more exact study of the science of breeding corn. If the various characteristics noted in ears and stalks of corn will but follow the laws of segregation and recombination as set forth by Mendel, we can da away with continual selection and pred corn for the various types which we want.

Take for instance the composition of corn; should it follow the above laws in breeding for starchy or horny endosperm all that we need to do will be to plant very hard or soft kernels and inbreed a large number of ears then plant the product in an isolated plot and those which produce type to one type are homozygous to that character. In this way, the one stroke, and in not more than three years time we should be able to produce altogether horny or starchy strains of corn. Other characters should be set in the same way as soon as their importance is discorered by an exact study of the character itself or correlation with other characters. 

CONCIUSION.

In the light of the preceeding data the following conclusions seem to be justified:

1. There are two forms of barrenness exhibited by the corn family. Certain stalks may be found which are absolutely barren and yet are growing under very favorable conditions. Barrenness may be inauced by crowding, by lack of plant food on a poor soil and by weakening the vitality of the seed as in the case of inbreeding. The first form is hereditary but there is no reason to suppose that that the latter can be inherited.

2. Hertilization of good ears from pollen of the first type of barren stalks produces seed which under all conditions throws a much higher percent of barrenness than does seed with no known barren tendency.

3. Increasing the stand under similar conditions increases the number of barren stalks produced in direct proportion to the increase in stand. This is evidently due to the effeot of crowding bringing out any weakmess which may exist in the individtal stalks.

4t Inbreeding eccording to work done here seems to decrease the vitality and vigor of corn causing a greater percent of barren stalks to appear.

5. Poor soll in which available plant food is badly lacking is one of the most fertile causes of barrenness. 6. A typical barren stalks is round, tapers from the 

base to the tassel, the leaves and sheathes are thick and fleshy and the stalk is full of sugar upon ripening. There is generally a good deal of red color exhibited in all parts of the plent at maturity. Seemingly on account of the fleshy leaves and sheathes the leaves assume a peculiar upstanding posture which is quite characteristic of the stalk.

7. There is a wide range in the percent of barrenness produced in the different varieties of corn which is probably one of the most fertile causes of the inability of those varieties to yield large amounts of grain.

8. Individual ears of any variety show a wide

range in the number of barren stalks produced. This is another evidence that some of the kernels on those ears were fertilized by a barren stalk and the tendency to barrenness was transmitted to the progeny.

9. Chemical analysis of barren and good stalks shows that barren ones contain more protein, fat, and nitrogen free extract than the productive. The difference is not great enough however to say thet the food which would normally have gone into the ear is lodged in the stalk. 



\section{4}

\section{BIBLIOGRAPHY.}

As previously mentioned no complete report on barrenness of corn has ever been published. The reforences to bulletin 107 of the University of Minnesota, and bulletins 91 and 112 of the Unibersity of Iebreska, bulletin 141 of the Bureau of Plant Industry, U.S.Dept. of Agriculture, and bulletin 165 of the Virginia Experiment Station werc the only articles derling. with the subject which could be found in our agriculturki literstare.

Finding that literature on the suiject vas not to be had the vriiter wrote to all the Experiment stations in the corn belt asking if they knew of any additionel data on the cubject. The replies from the men addressed constitute the main bibliography of this thesis and follow verbatim. 

FAyEtTEVILle, ARKansas, Mar .4,1911.

Mr. F. H. Demaree,

Acting Agronomist,

Columbia, Mo.

Dear Sif:

Replying to your inquiry regarding the heredity of

barrenness in corn will say that we have no literature on the

subject because our work like that of most other stations has

taken a trend along the line of working entirely with the most

practical problems discarding barrenness as far as possible without investigating it any further.

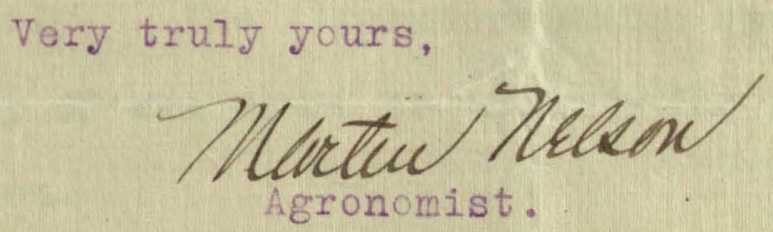

DIIT-CW 

DEPARTMENT OF

EXPERIMENTAL PLANT-BREEDING

HERBERT J. WEBBER, PROFESSOR

ARTHUR W. GILBERT, Assistant Professor

haRRY H. LOVE, Assibtant Professor

CLYDE E. LEIGHTY, AEsIBTANT

MAXWELL J. DORSEY, JR., AsSISTANT

ANNA M. ATWATER, LABORATORY ASSISTANT

HERBERT W. TEETER, SUPT. OF GARDEN.
CORNELL UNIVERSITY

COLLEGE OF AGRICULTURE

AND AGRICULTURAL EXPERIMENT STATION

L. H. BAILEY. Director

ITHACA, N. Y., February 28, 1911

Professor F. H. Demaree,

University of Missouri,

Cclumbia, Misscuri

Dear S1r:

I am in recelpt of your communication of February 24 In regard to the heredity of barrenness. So far as I am aware no literature has been published on this subject by cur station. In the study of the heredity of barrenness, I should think you would want to clearly distingulsh between the delimitation of sex to different individuals, which might occur and still not indicate barrenness particularly. The literature which has come out recently on the heredity or sex would be interesting for you to lock up in thls connection.

very truly yours,

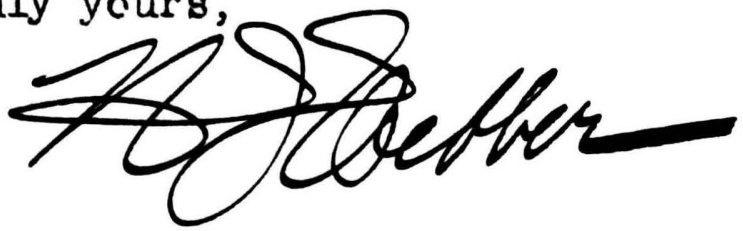



FAIRM CROPS

IICGHES, PROFESGOR

POTTER, A 4F'T. PROFEgSOR

CALDWELL, INETRUCTOR

BURNETT, PLANT BRKEDING

MOSHER, EXTENEION

FORMAN. FIELD BUIPERTTENDENT
IOWA STATE COLLEGE

College af Angrinulture AND

Anritultural Texperiment \$station

CHARLES F. CURTISS, DEAN AND DIRECTOR

DEPARTMENT OF AGRONOMY
SOILS

J. F. BARKER, ASS'T PROFKHAOR P. F. BROWN, BACTERIOLOGIST ROY E. GMITH, INSTRUCTOR S. L. JODIDI, KXPERIMENTALIAT A. A. WELI.S, ASB'T. EXPERTMUNTALIST A. H. SNYDKR, EXTENSION

AMES. IOWA March ; $9,1911$.

Professor F. H. Demaree,

University of Missouri,

Columbia, Mo.

Wy Dear Sir:

I am in receipt of your letter of some few days ago regarding the subject, "barrenness in corn". I think that there has been very little work done on this subject and I am certainly glad to know that you have some results which will be worth lecording. I moula suggest that you get in touch with the Illinois Experiment Station as they have made some observations on this subject. The Minnesota Experiment Station has made some observations but has I think published viry little or none of hthis information.

I thank you for your letter of a few days ago and also or the information regarding the boxing gloves. I am certainly very glad to have had the boys make use of them - and know that they went towards a good cause. Very truly yours,

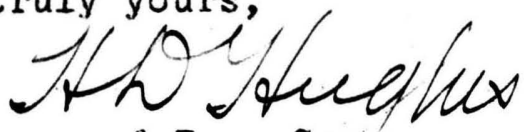

Professor of Farm Crops.

BDH-MAMB 

IMENT OF AGRONOMY.

JARDINE,

ROFESSON OF AQRONOMY

ND SUPERINTENDENT OF FAMM.

CALL,

SSISTANT PROTESSOR in BOILE.

sistant PRoTteseon in Crome.

SCHAFER,

ssistaNT IN CMOTE.

NASH,

SISTANT IN CROPE.

CHASE.

DISTANT IN FARM MECHANICE.

LILLL,

ISISTANT IN SOILE.

Manhattan, Kan., Mar. 10, 1911.

WILSON, FARM FONEMAN.

HE. JONES, CLENK.

\section{Kansas State Agricultural College \\ AND \\ EXPERIMENT STATION.}

Nr. F. H. Demaree,

Columbia, Missouri.

Dear Sir:--

Your letter to Professor Tenivek, concerming barrer stalks, at hand.

So far as I know, this Station has never worked out an:thing in connection with horeditary qualities on "Barrenness in Corn". I do not know of anvone else who has contributed anything on this subject by way of experimental work.

I am oorry that re cennot be of assistance to you in this matter.

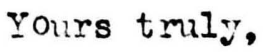

EGS-GHČ.

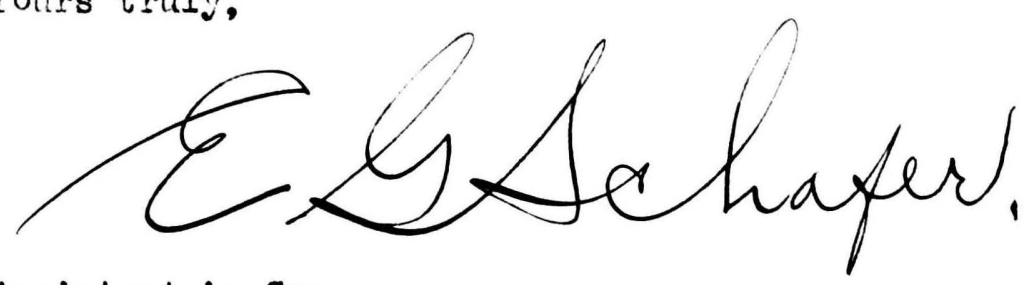

Assistant in Crops. 

State $\mathfrak{W}$ wiuxex

HENRY S. BARKER, PRESIDENT

Crallege of etgricultuxe

M. A. SCOVELL, DIRECTOR
DEPARTMENT OF AGRONOMY

GEO. ROBERTS, PROFESSOR

E. J. KINNEY, ASS'T PROFESSOR

bexingtan, Kn.., March 1,1911.

Professor F.H.Demaree,

College of Agriculture,

Columbia, Mo.

Dear Sir:

I have received your letter of February

24 th. We have no literature on the subject of

barrenness in corn and do not know of any that

has been published. Dr.Louie H.Smith of the

Illinois College of Agriculture has done some very

interesting work on this subject but I do not

think he has published his results.

Yours very truly,

Leotionesto 



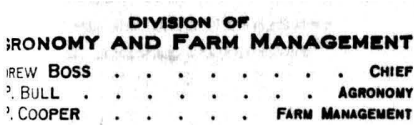

joject_ Corn.

Ur. T. H. Demareo, Columbia, Mo.

Dear Sir; -

I regret that I do not have anything published which treats specifically upon the subject of barreness in corn. The only thing we have, you will find in my bulletin from this Station, No.107.

Very truly yours,

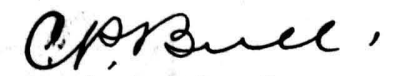

${ }^{C} \mathrm{~PB}-\mathrm{J}$

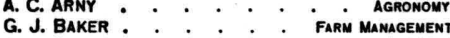

JOHN HOFFMAN * ., asst. FARM SUPT. LEE ALEXANOER
UNIVERSITY FARM, ST. PAUL. MINN. Nar. 4, 1911.

Associate Professor. 

THE UNIVERSITY OF NEBRASKA OOLLEG E OF AGRIOULTURE AGRIOUITURAL EXPERIMENT STATION LINCOLN
A. Bernmte, Dian ANd Dirmotor iV. MAKGHALL, FXeutivh OLERK HEADS OF DEPARTM ENTS S. Wilcox, AGR'L Botany

J. ALWAY, AGR'L CheMigThX

W. Chase, Agrit Enginereting

W. Pugglet, AgBonomy and Farm Managhant

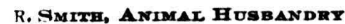

H. GAIN, ANmat PAThoLogy
A. L. HA BCKER. DATHY HUGBANDKY LA WR ENOE BRUNhe, ENTOMOLOGY h. G. Montgonery, Exp'L Aghonomy F. J. Phillips, Formstry

R. A. KMERson, Horticulturh

G. A. Loveland, Metholologt

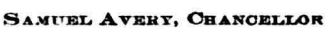

J. S. Dalms, Finanotay ghometaky

March 15, 1911.

Professor F. H. Damaree,

Columbia, Missouri.

Dear Prof. Damaree-

Your letter of February 24 at hand asking for information influenoing barrenness in corn. The only publications I have on this matter are found in Bulletin 91 of this Fxperiment station, a copy of which you probably have, but I am sending another, under separate cover.

Very truly yours,

FGLU/O

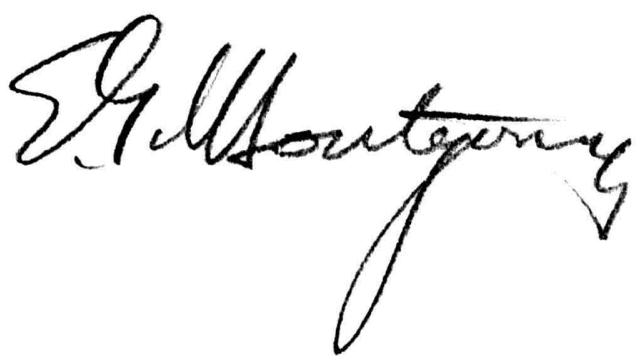





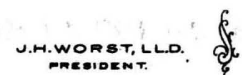

NORTH DA ROTA AGFIOULTUFAL O OLLIE

GOVERNMENT EXPERIMENT STATION

AGRICULTURAL COLLIER, NORTH DAKOTA.

DEPARTMENT OF AGRICULTURE

J.H.SHEPPERD.

February 28, 1911.

Mir. F. H. Demure,

Columbia, Mo.

Dear Sir:

This station has no publication on the

heredity cf bareness in corn breeding.

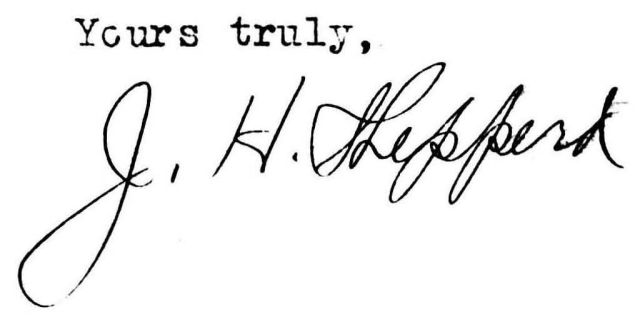



OHIO AGRIGULTURAL EXPERIMENT STATION

Chas. E. Thorne, Director

WOOSTER, OHIO

DEPARTMENT OF AGRONOMY

C. G. Williams, Chilef

F. A. Welton, Assistant

C. A. Patton, Field Assistant

William Holmes, Farm Foreman

E. C. Morr, Clerk

Feb. 27, 1911.

Frof. F. H. Dwmaree,

Columbia, Ho.

Dear Sir:

Replying to your letter of Feb. 24, I regret to say that we have no publications regarding barrenness in corn. Te have made some observations and may possibly have given something in addresses, but have nothing we can send out.

Cordially yours,

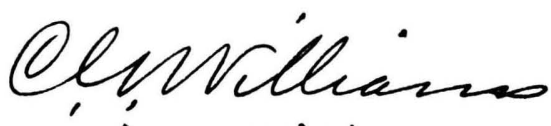

III

Agronomist. 

B. C. Prtwuck

ssistant Directo L. L. LEwis

V. A. LinkLater imal Husbandman

Roy C. Potrs

Dairyman

C. E. Sanbork

has. K. Francis

Chemist

N. O. Booth

Horticulturist
Address All Communications to the Experiment Station, Stillwater, Okla.

\section{Bklahmma Agxicultuxal fixpeximent Station}

JAMES A. WILSON, DIRECTOR

STILLWATER
O. O. ChuRCHILL Agronomist

A. H. WRIGH

A. H. W
Assistant Agronomist

R. O. BAIRD

Assistant Chemist

A. L. LOVETT

Assistant Entomologist

J. L. McKeOWN

inancial Secretary

W. W. Evans

Farm Superintendent

Lula TOURTEllotTe

Clerk

Feb. 28, 1911.

Mr. F. H. Demaree,

University of Missouri,

Columbia, Mo.

Dear Sir:

This Station has no publication on the subject which you inquire about in your recent letter. I am corry we can be of no benefit to you but we have made no investigation along this line.

OOC-IM

Yours truly,

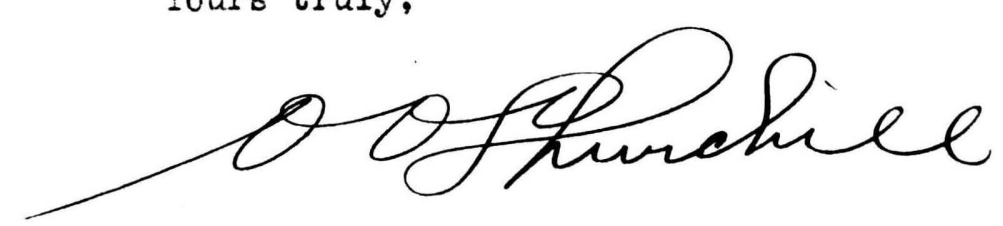



the penNsylvania state college SCHOOL OF AGRICULTURE AND EXPERIMENT STATION

PARTMENT OF AGRONOMY

state college. pa.

March 7, 1911.

Mr. F. H. Demaree,

Dept. of Agronomy,

Columbia, Mo.

Dear Sir:

I am unable to supply you with any literature on the "Heredity of Barrenness in Corn". You will find a number of experiment Station Bulletins that give results of the determinations of the extent of barrenness in different varieties and under different conditions.

I presume that Mr. L. H. Smith of the Illinois Experiment Station is better qualified to advise you concerning the securing of literature along this line than any other man in the United States.

$$
\begin{aligned}
& \text { Yours very truly, } \\
& \text { Srant D. Sardecen. }
\end{aligned}
$$

FDG-G

Professor of Agronomy. 

HEADS OF DEPARTMENTE

c. ARTHUR, Botany

L. ChrIstrm, Ifrtension Work

A. Craig, Veterinary Solence

F. HUNzIKRR.. Dairy Husbandry

J. Jorms, JR., State Chemist (Fertilizer

and Feeding Stuff Control)

H. SRTwNER, Animal Husbandry

yES TroOP, Horticulture and Fntomology

T. Wranozo, Bolls and Crops

\section{PURDUE UNIVERSITY}

Agricultural Experiment Station

ARTHUR COS8, DIRECTOR
SOILS AND CROPS

A. T. WIANoko, Ohief

B. D. Conner, Ohemist

M. L. Frsher, Associate in Orops

J. B. Aвbotr, Associate in Solls

C. O. Cromer, Assistant in Orops

Lafayette, Ind. Mar . 3, 1911

Prof. F. H. Demaree,

College of Agrioulture,

Columbia, Mo.

lify dear Demaree:-

In reply to jours of the 24 th ult. I beg to say that we have not published anything conoerning barrenness in corn, although we have a great deal of data in the records of our varfous corn breeding plots. This has not even been summarized so I am unable to state the results and just now, I have not time to look the matter up. If, however, you can use it a little later. I shall be glad to look it up and give you the prinoipal results.

Very truly yours,

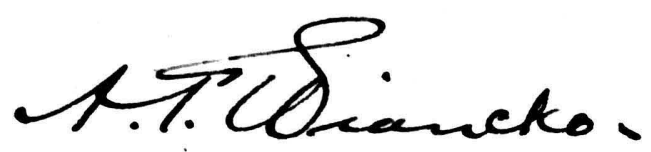

Chiof in Soils and Crops. 

W. WILSON. M. S. A., DIRECTOR

ANIMAL HUSBANDRY

HANSEN, M. S.,VICE-DIRECTOR

RT CULTURE AND FORESTRY

Ames H. Shepard. B. S. CHEMISTRY

L. MOORE, B. S., D. V. S.

VETERINARY
Sinth 百aknta

Anrinultural Experimunt Station

BROOKINGS, S. D. robert L. Slagle, A. M.. Ph. D. President of College

CLIFFORD WILLIS, M, S. AGRONOMY AND SUPT. OF SUB-STATION edgar w. Olive. A. M., Ph. D. BOTANY

Christian Larsen, M. S. A

DAIRY HUSBandMAN

R. A. LARSON. SECRETARY

Harch 1, 1911.

Mr. F. H. Demaree,

Acting Agronomist,

University of Mo., Columbia, Mo.

Dear Sir:

In reply to yours of Feb. 24th for literdture on the subject of barrenness in corn, I am sorry to state that we have none here at this institution.

JWW-J

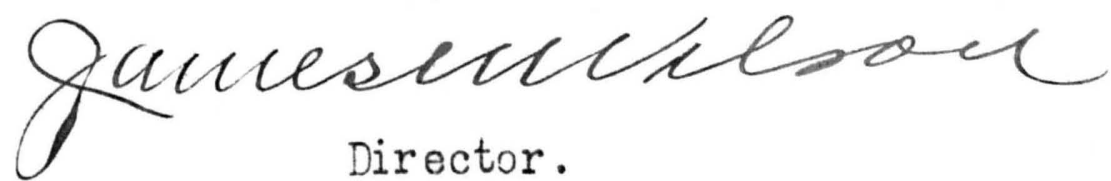



HEADS OF DEPARTMENTS

BURRILL, Botany

IcINTOSH, Veterinary Science

.HoPKINs, Agronomy and Chemistry

IAVENPORT, Thremmatology

BLAIR, Horticulture

P. MUMFORD, Animal Husbandry

I. FrASER, Dairy Husbandry

iEL BEVIER, Household Science

RANKIN. Agricultural Extension

\section{UNIVERSITY OF ILLINOIS \\ COLLEGE OF AGRICULTURE}

AND

AGRICULTURAL EXPERIMENT STATION

E. DAVENPORT. DeAN AND Director

Urbana, Illinois, February 27, 1911
C. G. HopkINs, Soil Fertility

L. H. SMITH, Plant Breeding

J. G. MOSIER, Soil Physics

J. H. PETTIT, Soil Fertility

A. N. HUME, Crop Production

J. D. CEADHE Crop Production

W. D. CENTER, Crop Production

A. F. GUSTAFSON, Soil Physics

A. F. GUSTAFsON, Chemistry

A. LUMBRICK, Crop Production

E. A. WHITE, Farm Mechanic

O S. FISHER, Soil Fertility

C. C. LOGAN, Soll Physics

J. A. AUMER, Chemistry

GERTRUDE NIEDERMAN, Chemistry

R. G. SMITH, Chemistry

R. G. SMITH, Chemistry

I. W. DICKERSON, Farm Mechanics

S. V. HoLT, Soil Physics

H. W. STEWART. Soil Physics

H. C. WHEELER. Soil Physics

J. E. WHITCHURCH, Soil Fertility

E. E. HoskINs. Soil Fertility

FrancEs D. ABBOTT, Chemistry

W. H. SACHS. Chemistry and Soils

F. C. GRANNIS, Soil Fertility

E. M. MCDONALD, Crop Production

W. R. LEIGHTY, Chemistry

Professor F.H.Demaree

University of Missouri

Columbia, Missouri

ify dear Professor Demaree:

Your inquiry concerning barrenness of corn is at hand. In

reply I may say that we have as yet issued no formal publication concerning this matter,altho the matter may have been mentioned incidentally

in some general address on corn breeding. This is an interesting topic

and it seems strange that there is such a dearth of literature. But

I think that you are right in the fact that scarcely any does exist

upon this particular subject. I shall be interested in your thesis

when it appears. In case I happen to run across anything bearing

upon the topic, I shall be very glad to let you know concerning it.

With kind regards, I am,

LHS/AT

very truly yours,

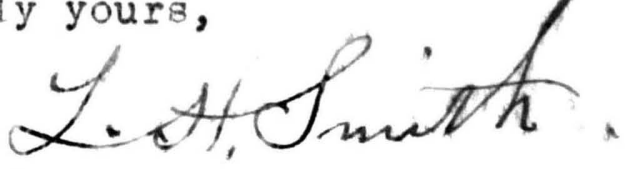



A. HENRY, EMERITUS PROF. OF AQR.

S. ALEXANDER, VET, SCIENCE;

STALLION LICENSING.

COLE, EXPERIMENTAL BREEDING. . FARRINGTON, DAIRY HUSBANDRY,

G. HALPIN, POULTRY HUSBANDRY.

B. HART, AGR. CHEMISTRY.

GASTINGS, Agr. BACTERIOLOGY.

HATCH, AGR. EDUCATION:

SECRETARY OF AGR. EXTENSION

C. HUMPHREY, ANIMAL HUSBANDRY.

R. JONES, PLANT PATHOLOQY.

. MARLATT, HOME ECONOMISS,

C. MARQUIS, AGR. JOURNALISM

AQR. EDITOR.

G. MOORE, HORTICULTURE.

A. MOORE, AGRONOMY.

A. OCOCK, AGR. ENGINEERING.

SANDERS, ECONOMIC ENTOMOLOOY

NURSERY INSPECTION.

C. TAYLOR, AQR. ECONOMICS.

R. WHITSON, SOILS.

WOLL, FEED AN D FERTILIZER

INSTECTION: DAMYTEST

\section{THE UNIVERSITY OF WISCONSIN}

\section{COLLEGE OF AGRICULTURE \\ AND}

AGRICULTURAL EXPERIMENT STATION

R. A. MOORE

C. P. NORGORD

A. L. STONE

E. J. DELWICHE

CHARLES R. VAN HISE, PRESIDENT OF THE UNIVERSITY.

H. L. RUSSELL, DEAN AND DIRECTOR. D. H. OTIS, ASST. TO THE DEAN.

L. F. GRABER

B. D. LEITH

MADISON, wis. March $3,1911$.

Prof. F. H. Demaree,

Columbia, Missouri.

My dear Sir:

Yours of recent date in regard to the

heredity of barrenness in corn came duly to hand.

I regret exceedingly we have not carried on any

experimental work along the line you are working.

Regretting I am unable to assist you at

this time, I am

RAM-NWL.

Sincerely yours,

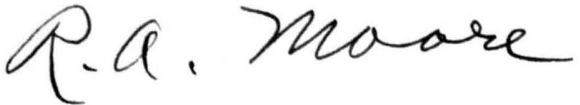





\section{PHOTOGRAPHS.}

THE FOLLOWING PHOTOGRAPHS SHOW MORE CLEARLY MIIAN

WORDS THE FIELD CONDITION OF THE CORH RURNISHING THE DATA

HEREIN CONTAINED; EARS OF CORN USED, TYPICAL

BARREN STAIKS AND PRODUCTIVE ONES. 

PHOTO. I

HAND FERTILIZED EARS USED IN 1909.

EARS DEFORMED, KERHELS GOOD.

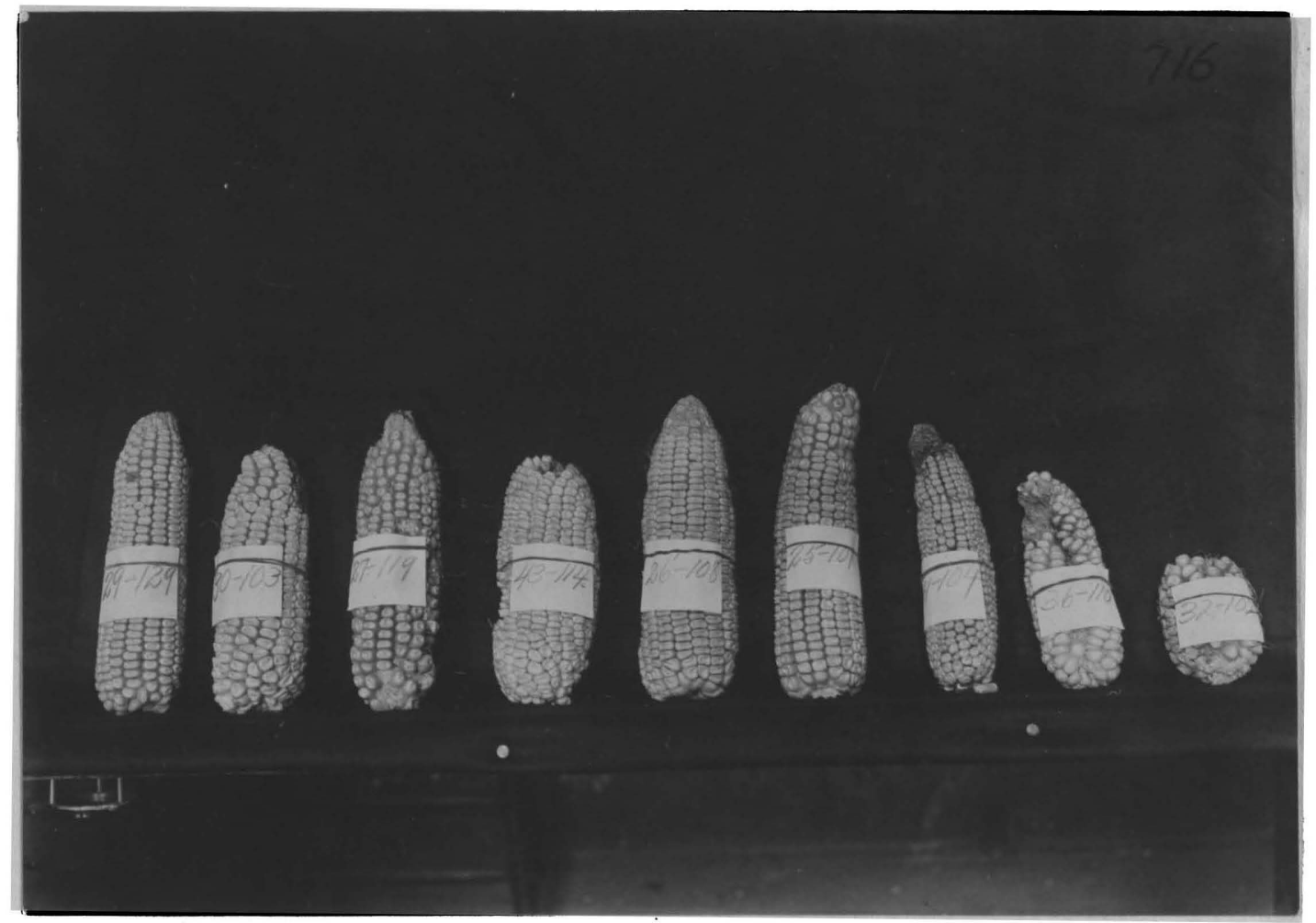




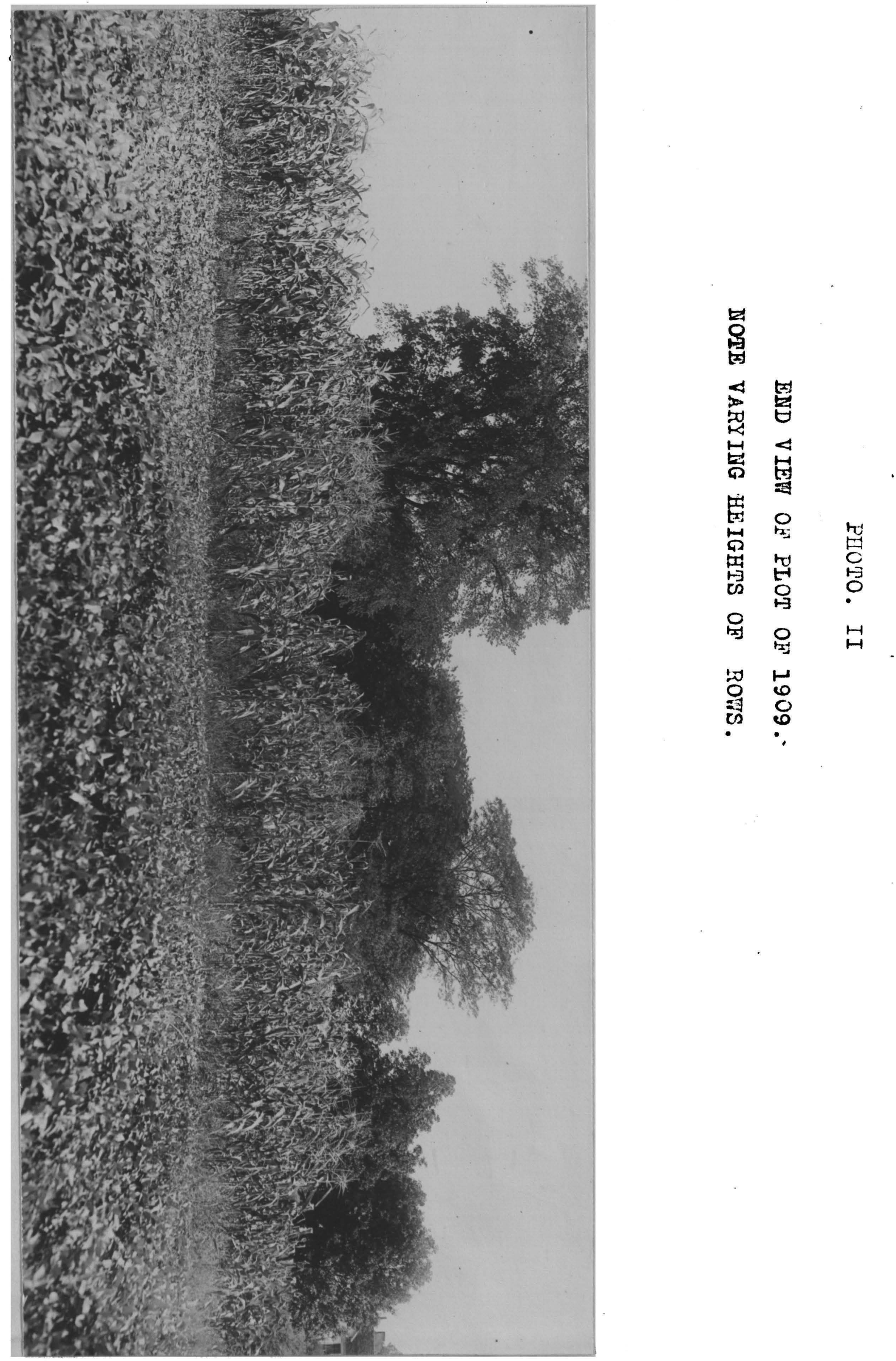

SIDE VIEV OF PLOT OF 1909, SHOFING DIVISION

BETWEEN ROWS. THIS CORN DOES NOT SEEM

TO LACK VIGOR.

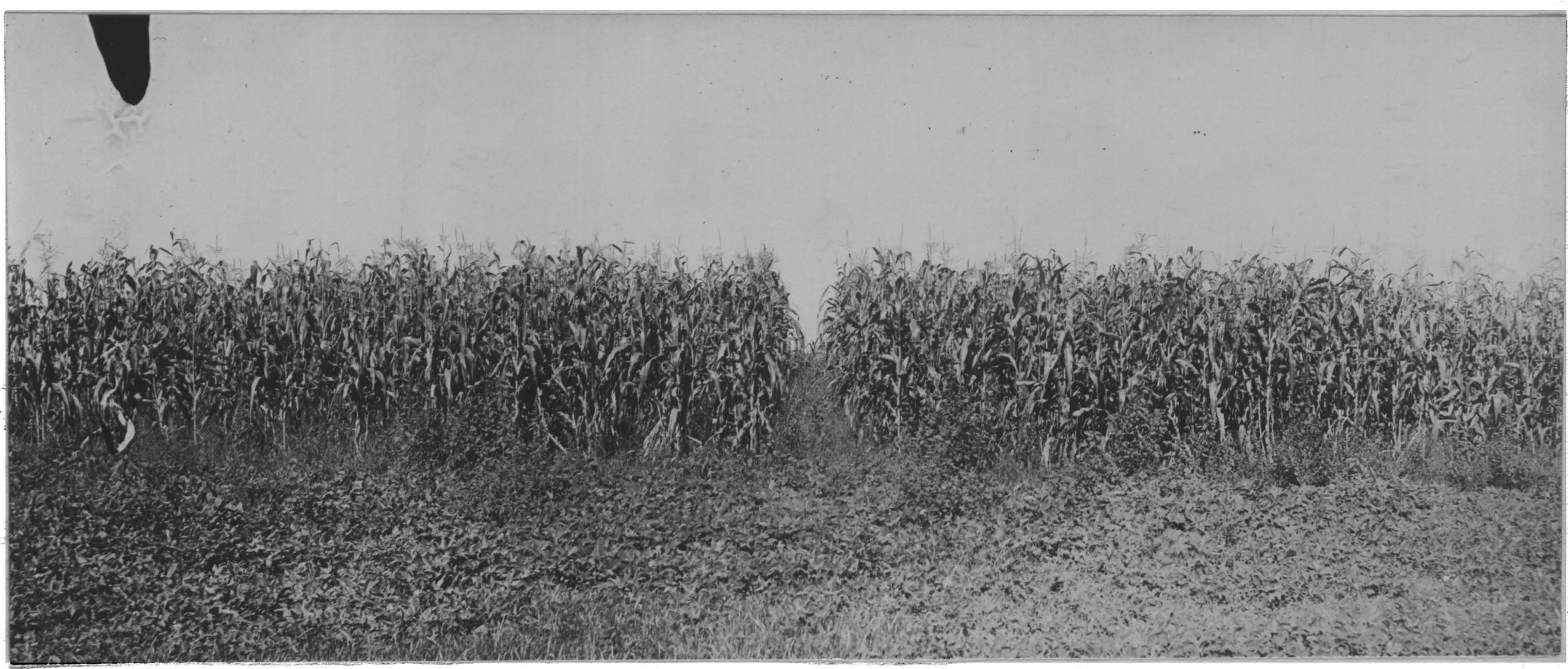



PHOTO. IV

EARS ON CORN USED IN 1910.

BARREN STALK PLOI.

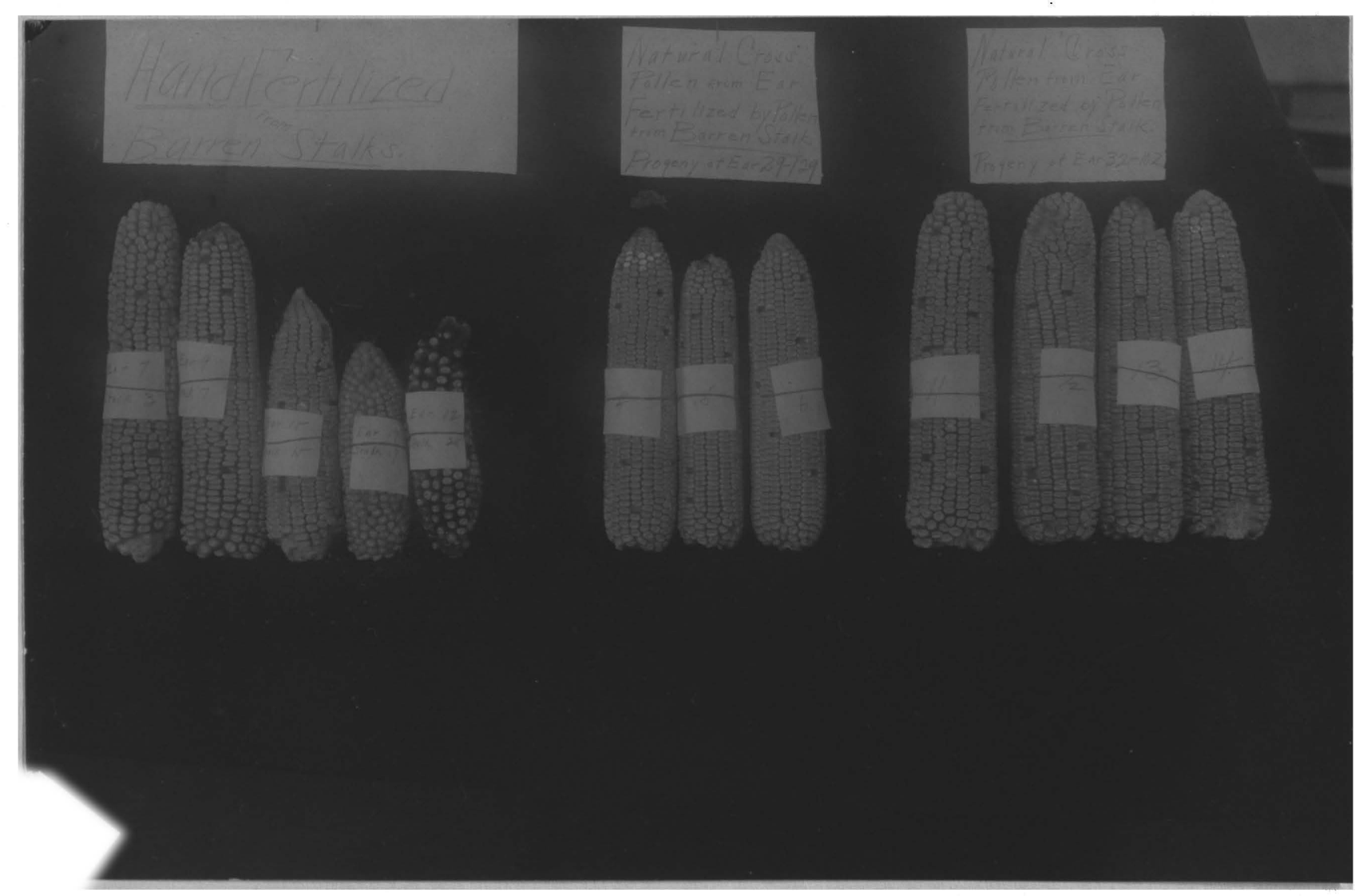



IHOTO. V

SHOWING DETAILS OF THE HALD POLIENATOR.

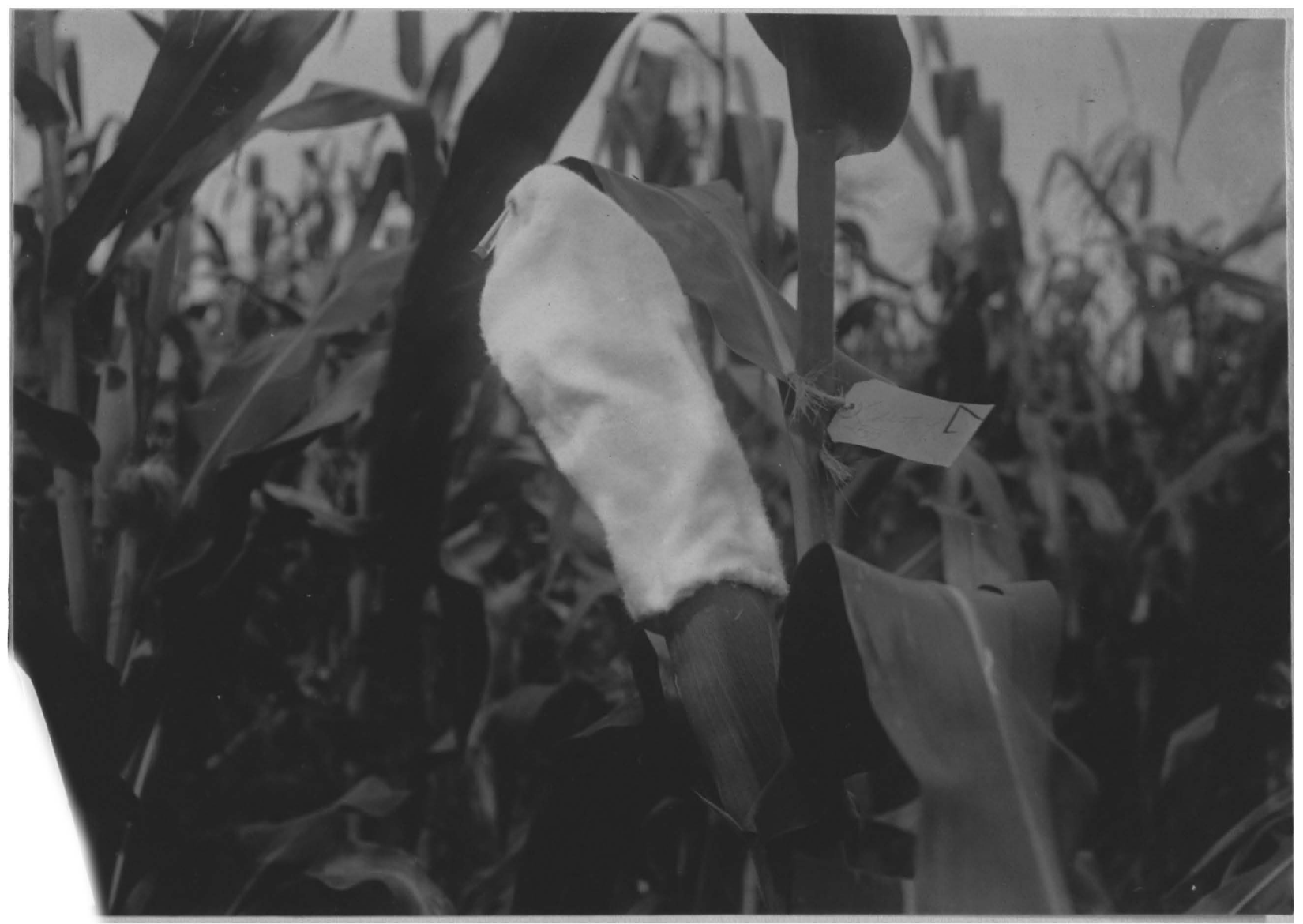





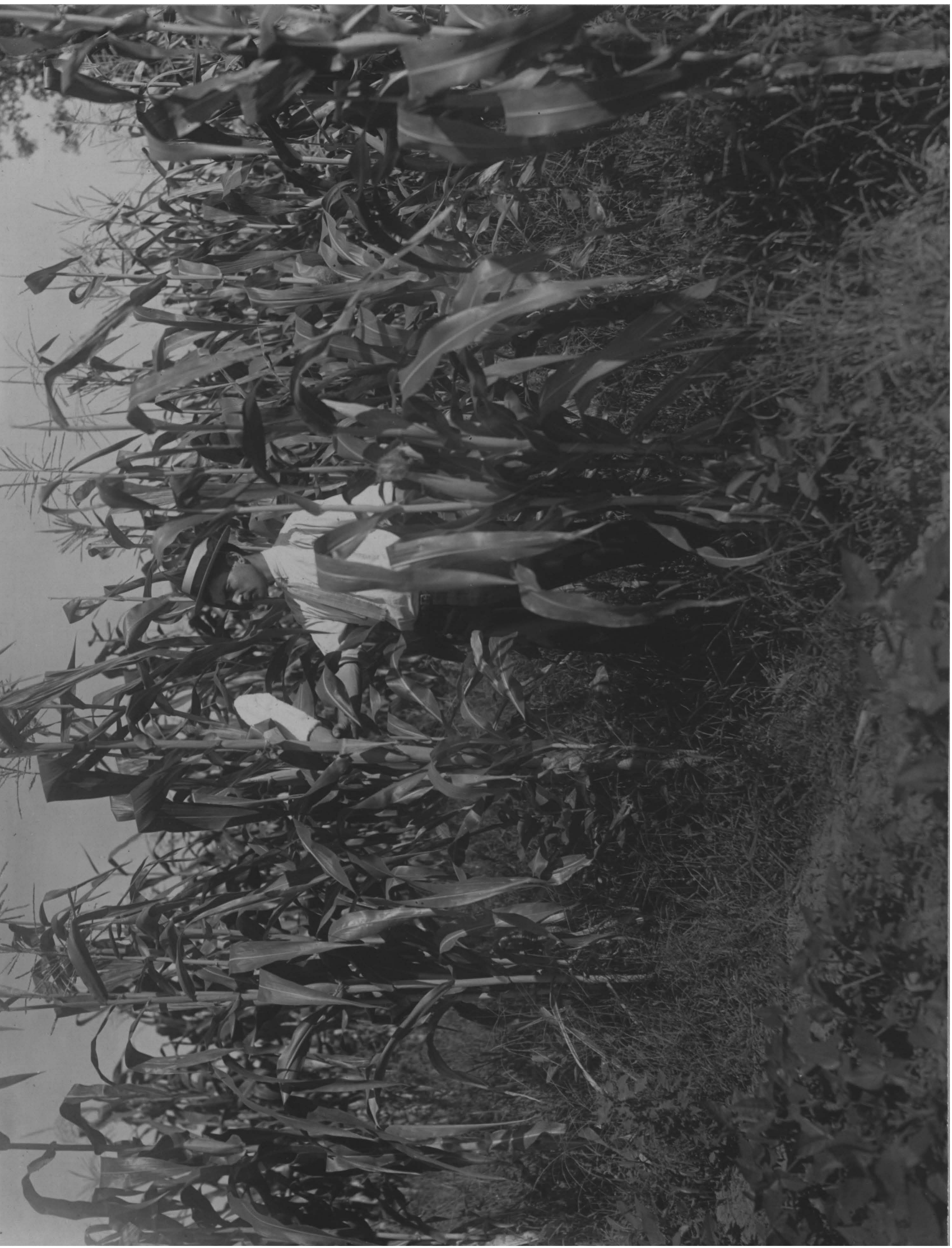



PHOTO. VII

EAR 9, SIRE STALK $\%$, HAID FOLIENATED SEASOIN $\mathbf{H} 909$.

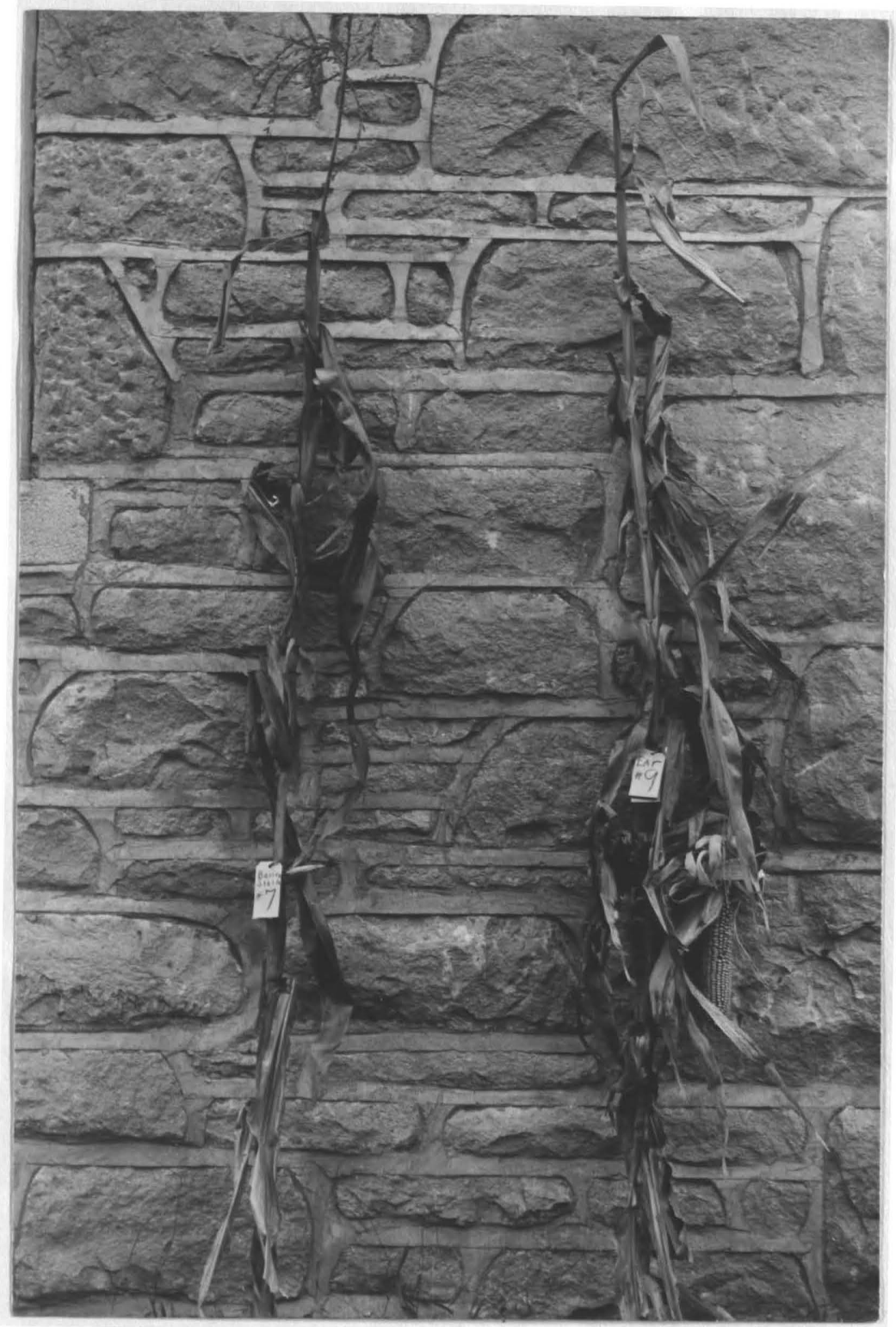



PHOTO. VIII

LAR 7, SIRE SIALK 3, HAND FOLLINATED

SEASON 1909.

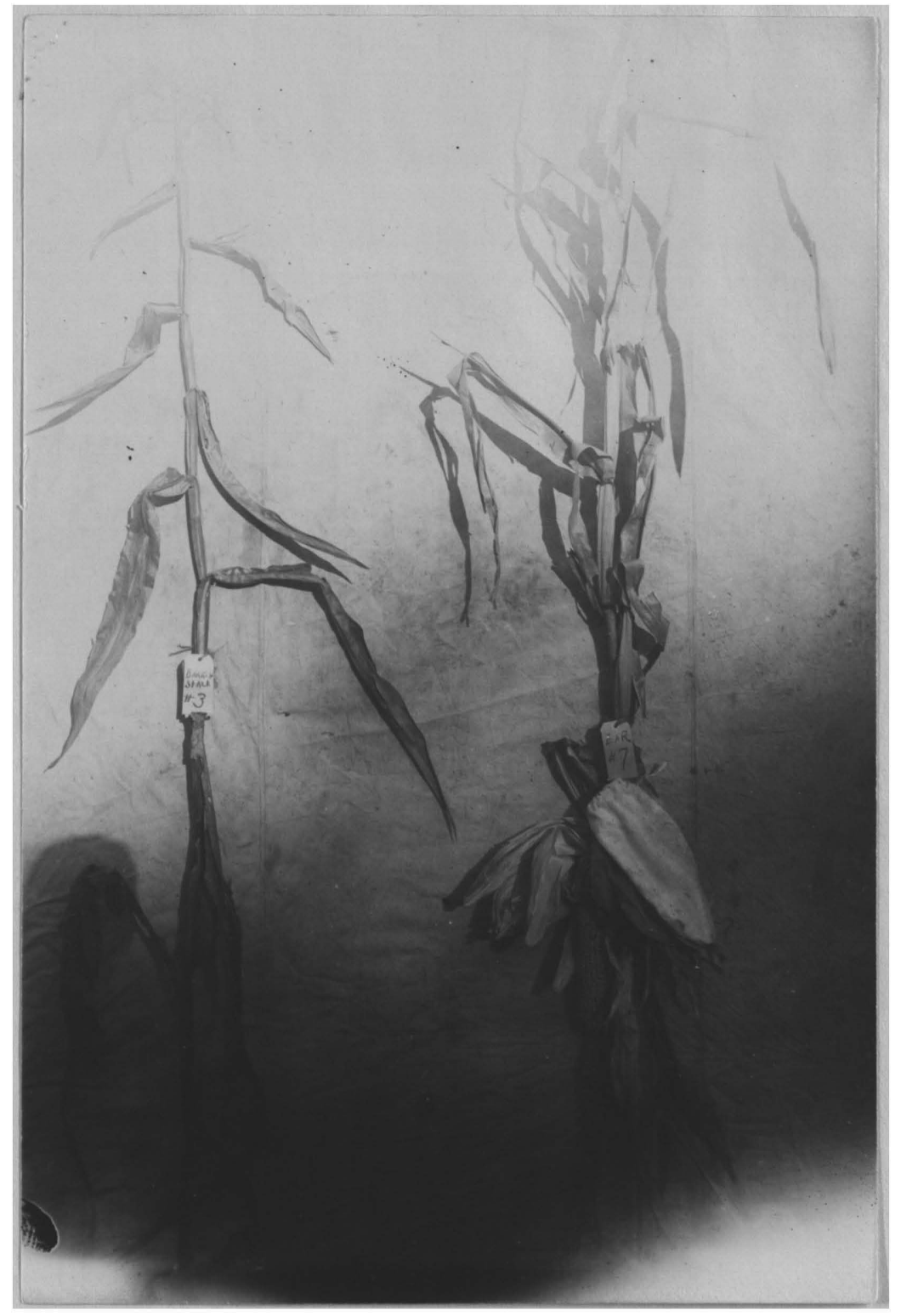





\section{PHOTO. IX}

\section{INBRED 10 ON IHE RIGHT. CROSS}

$10 \times 67$ ON THE IEHT.

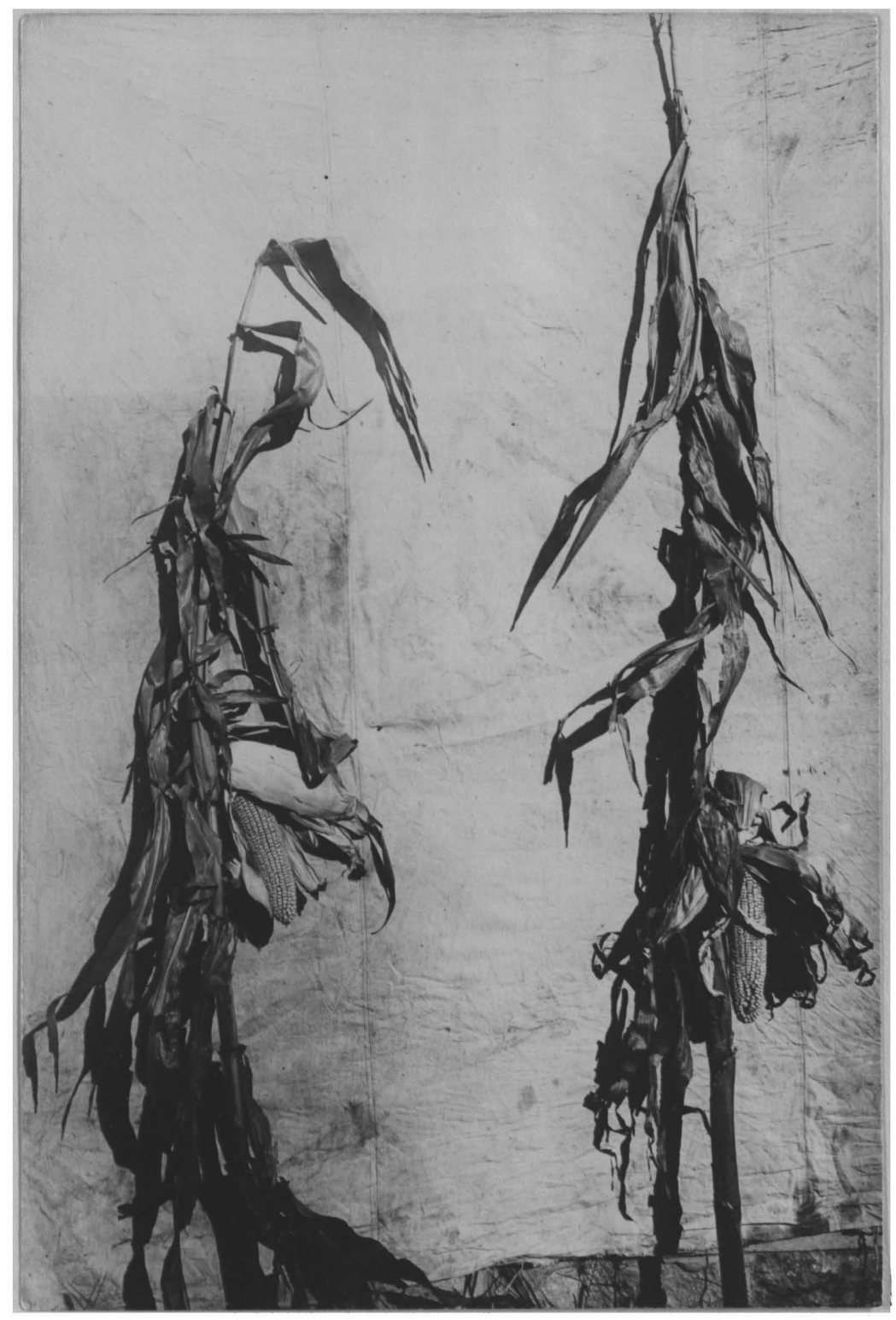



PHOTd. X

BARREN STALKS 7 AND 8. HOTE TYICAL POSE.

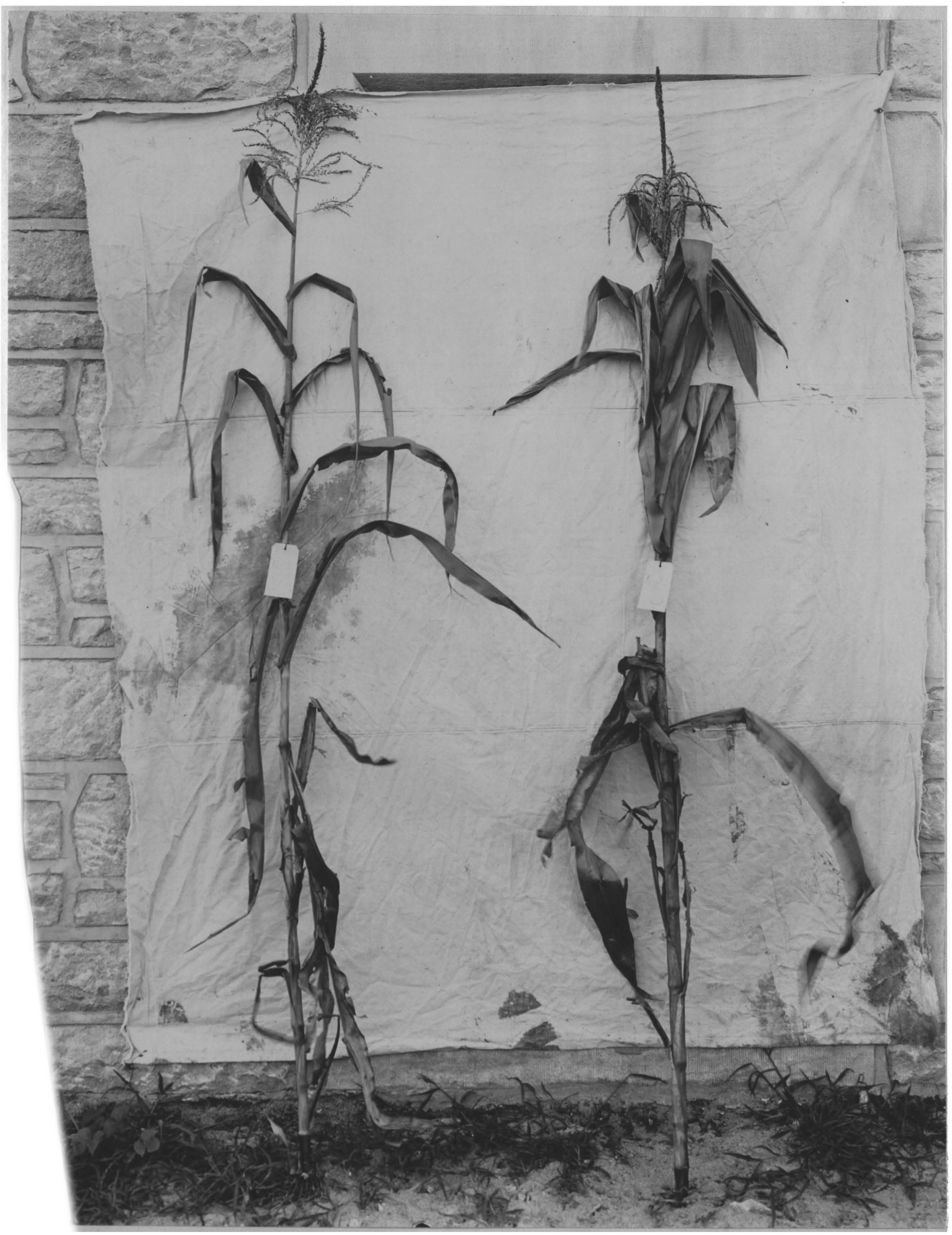



PHOTO. XI

THREE BARREN STALKS DISSECTED---6,7, AND 8 . NOTE RUDIMENTARY SHOOTS.

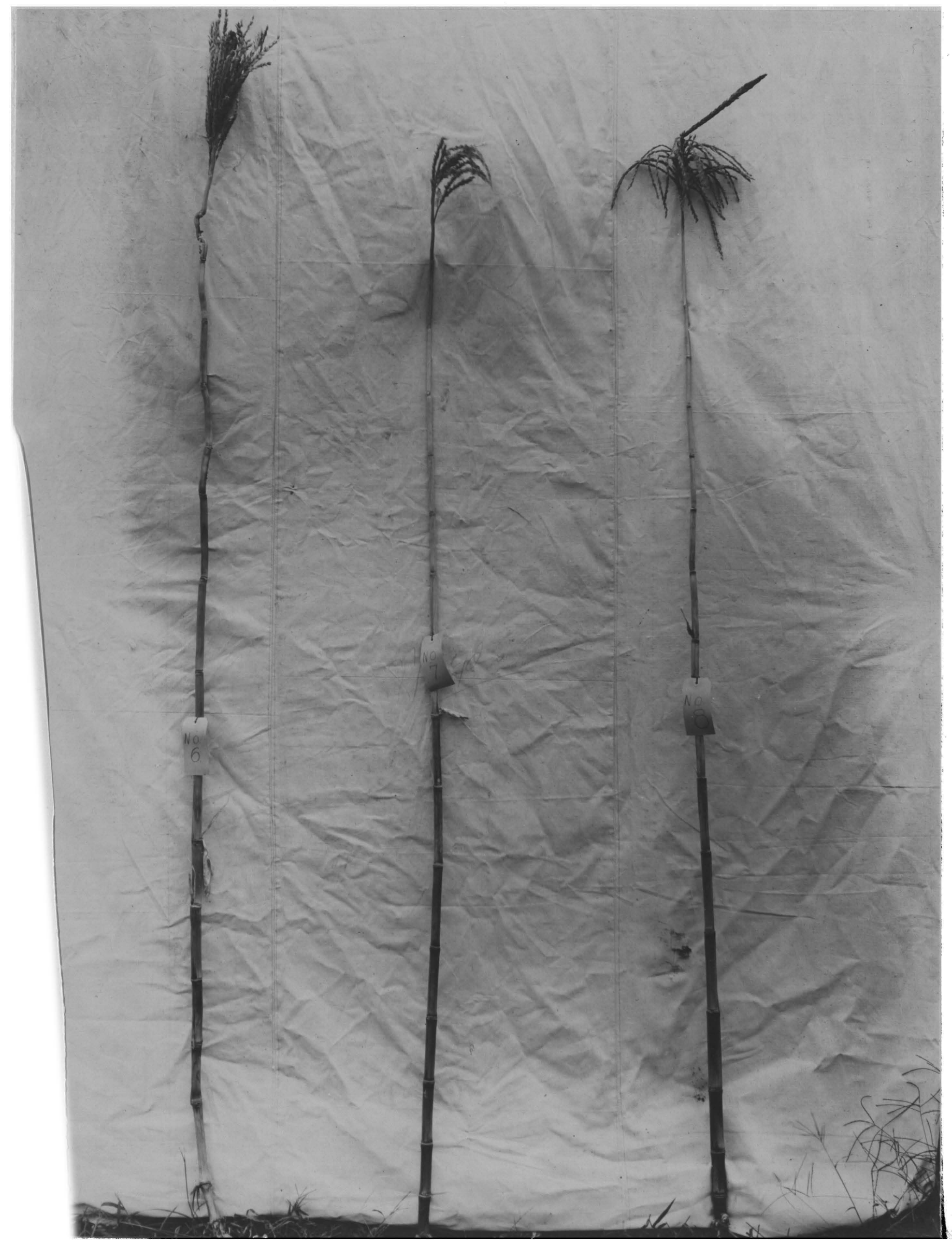





\section{PHOTO. XII}

BARREN STALK 6,SHOWING A PECULIAR

LEAF FORMATION, ARRANGED IN WHORLS

OF THREE.

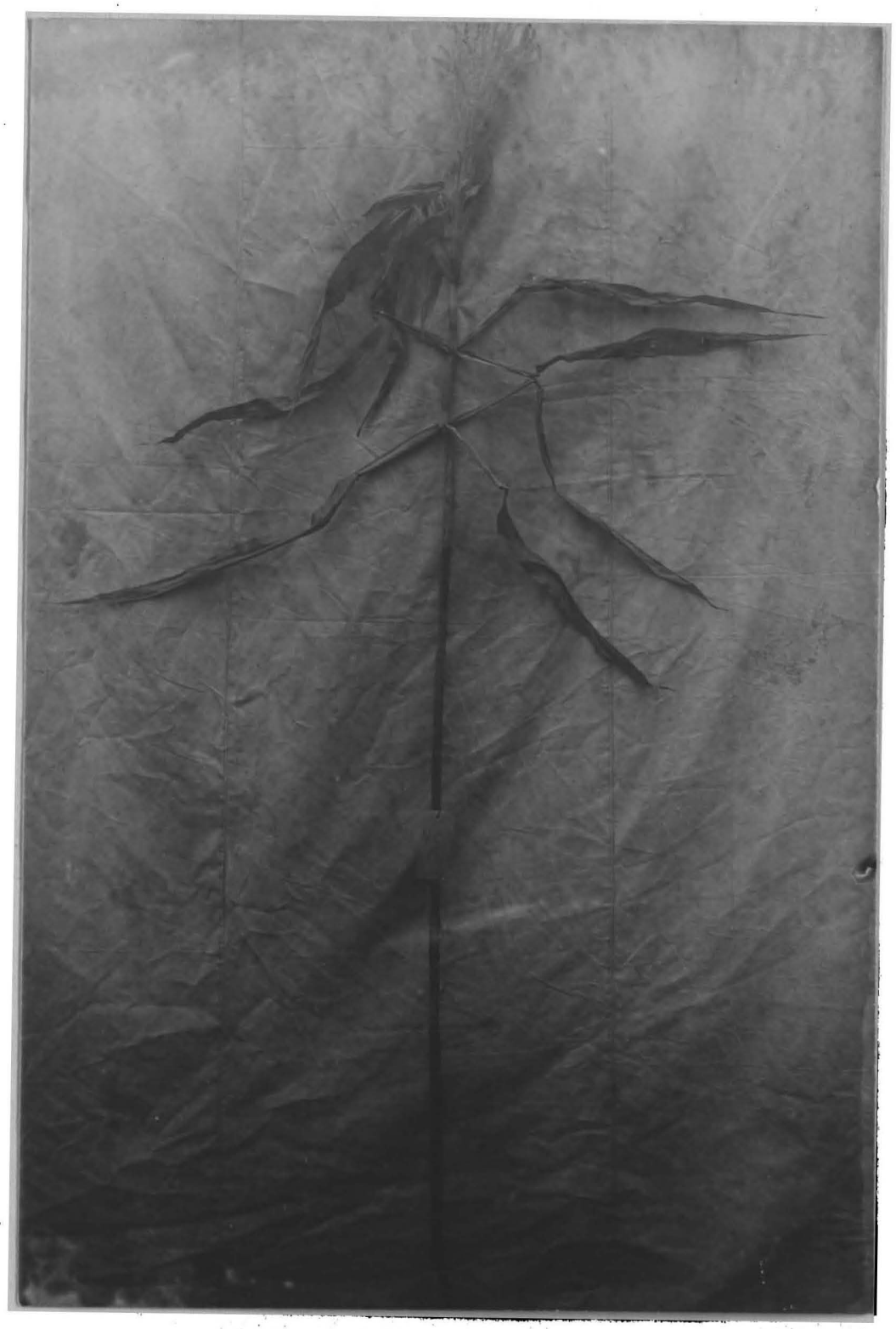



PHOTO. XIII

BARREN STALK 25.

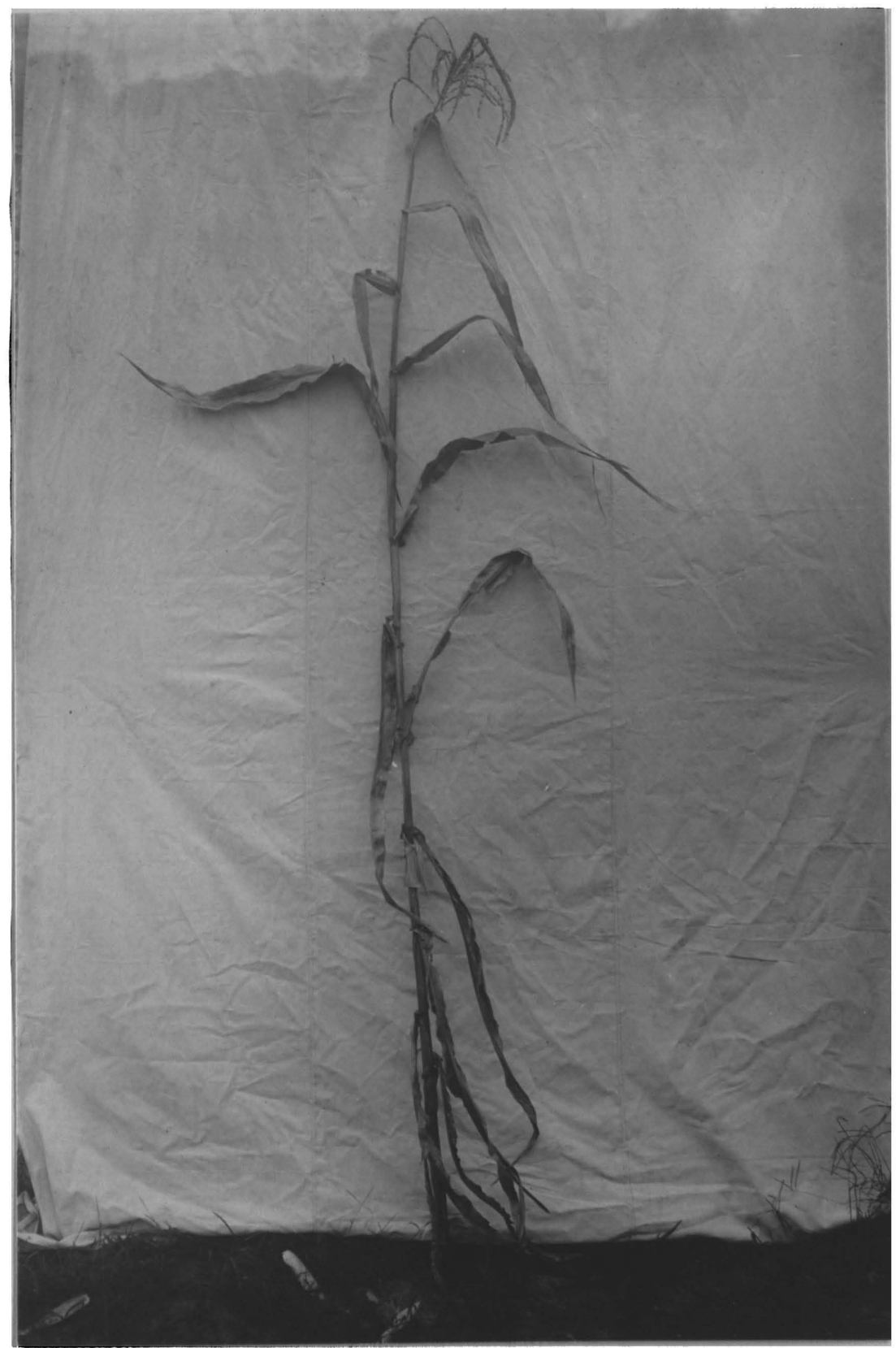



PHOTO. XIVं.

EIGHT STALKS SHOWING THE RANGES OF PRODUCTION.

AS SEIECTED FROM THE FIELD.

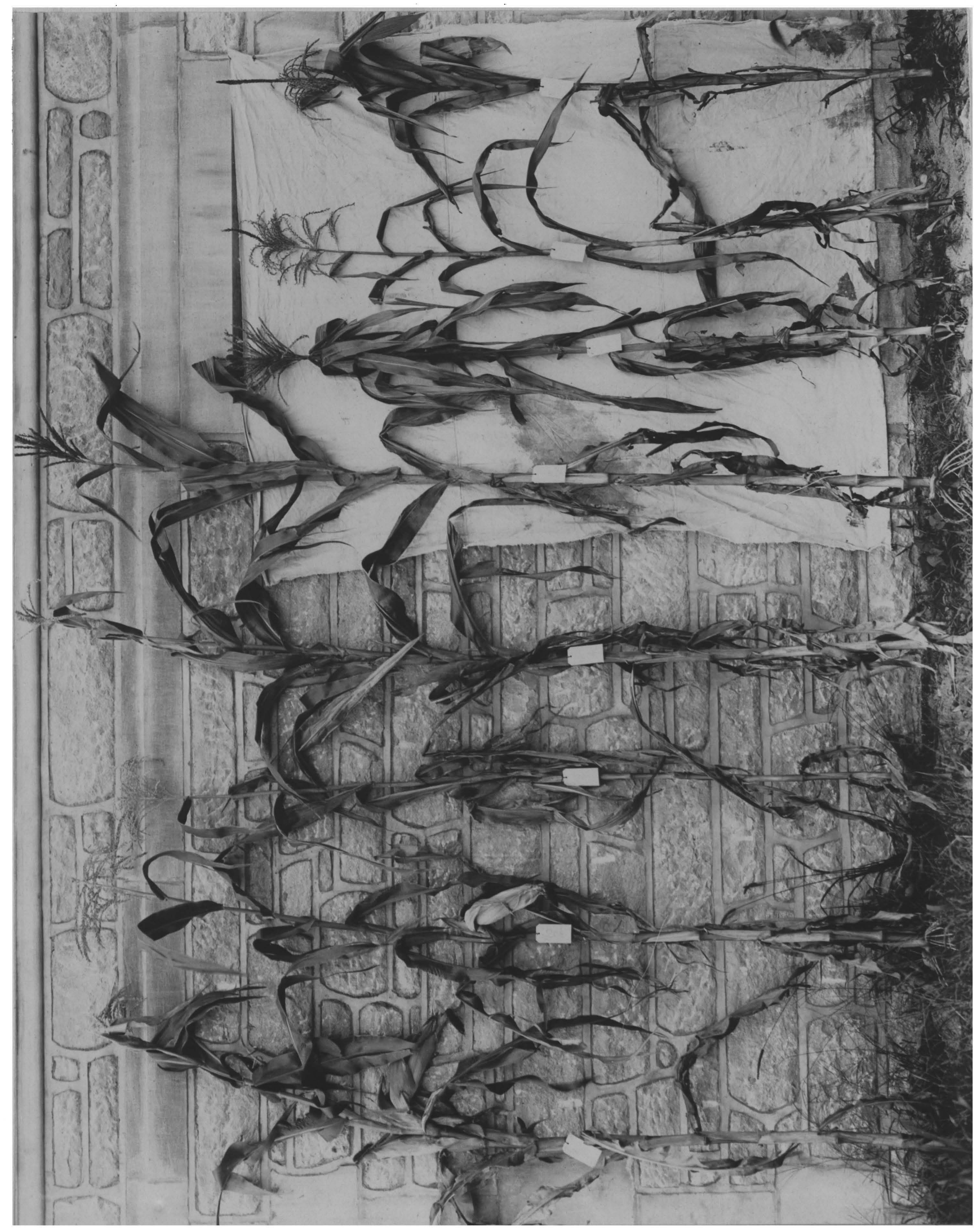



PHOTO. XV

EIGHT STALKS EHOWING THE RANGLS OF PRODUCPION. DISSECTED.

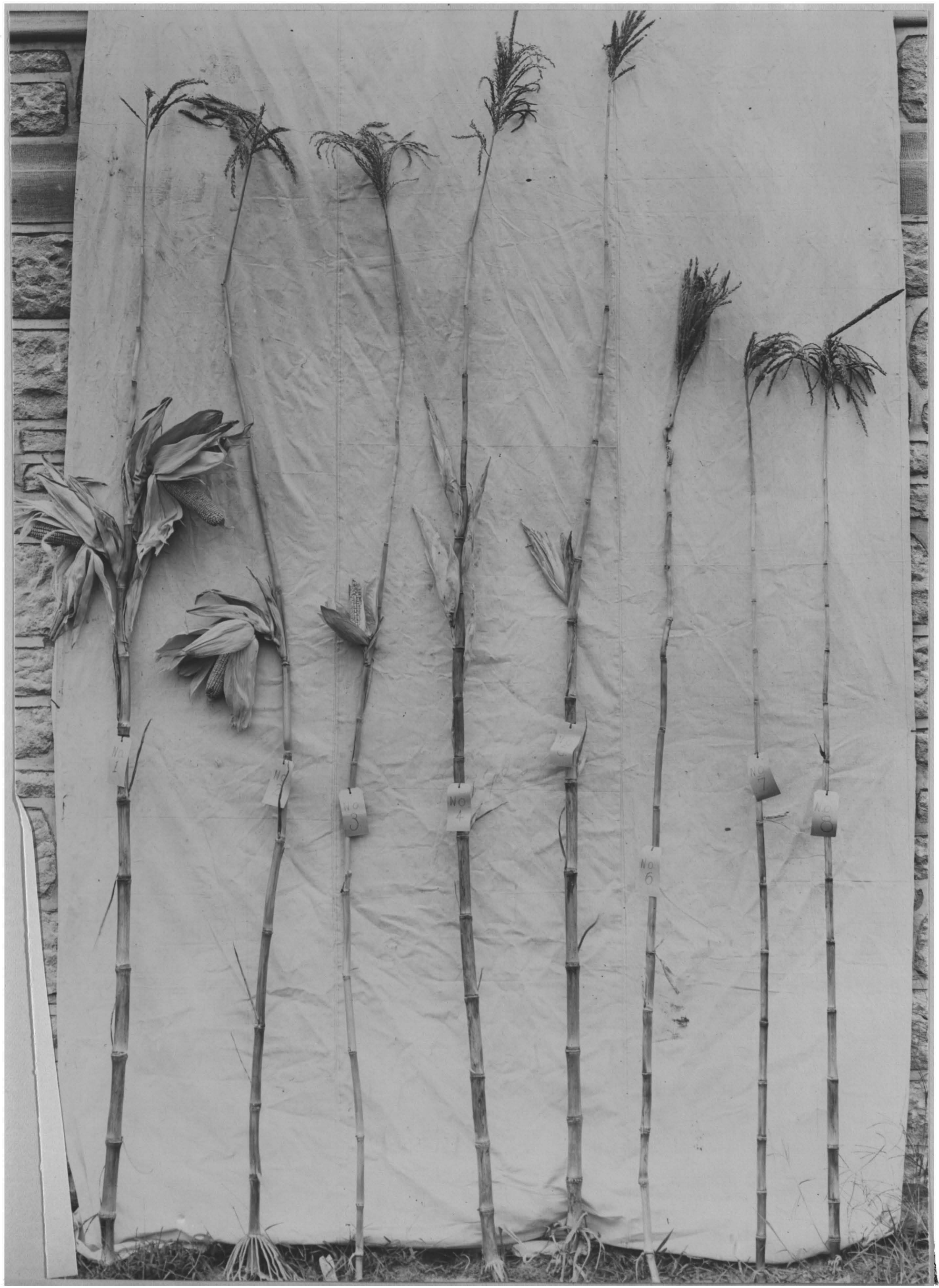



THE EXIREIES OT PRODUCTION.

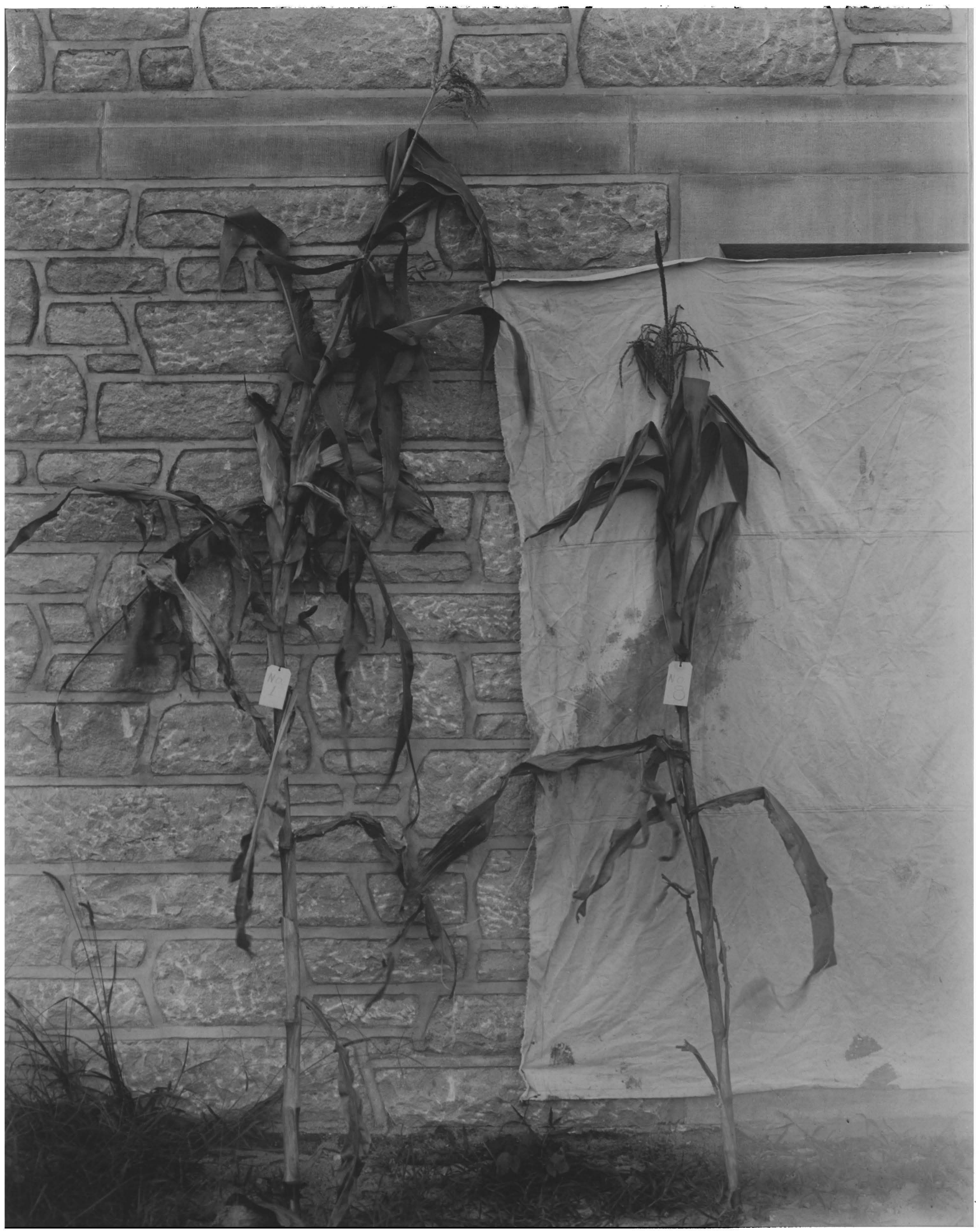



PHONO. XVII

OLN IMMENSE STAIK, IEREL SHOOTS, HO GRAIN.

WHY SUCH A STALK?

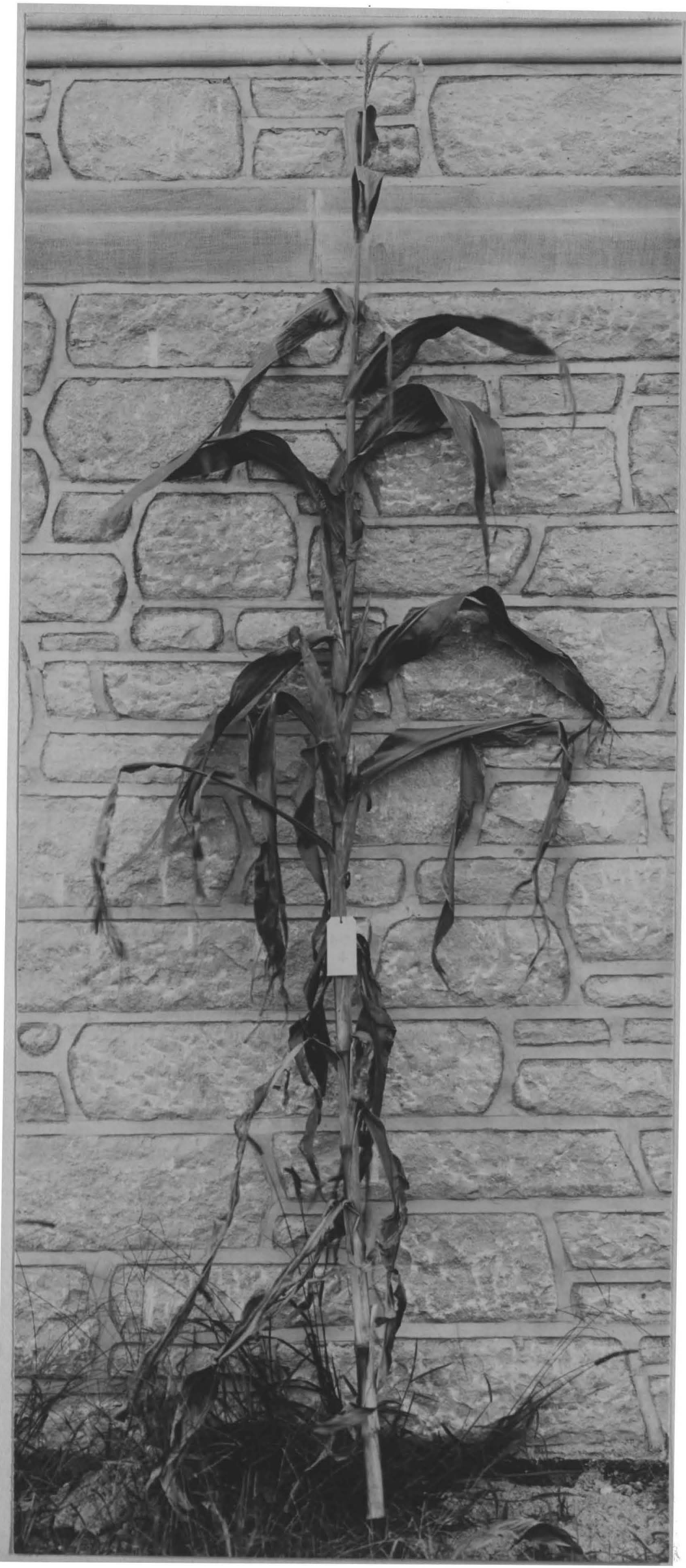





$$
\begin{gathered}
\text { PHOTO. XVIII } \\
\text { ANOTHER EXAMPLE OF GHE DIFHERENCE } \\
\text { BETTEEI L. GOOD AND A BAEREI STAIK. IOTE } \\
\text { POSE OF LACH. }
\end{gathered}
$$

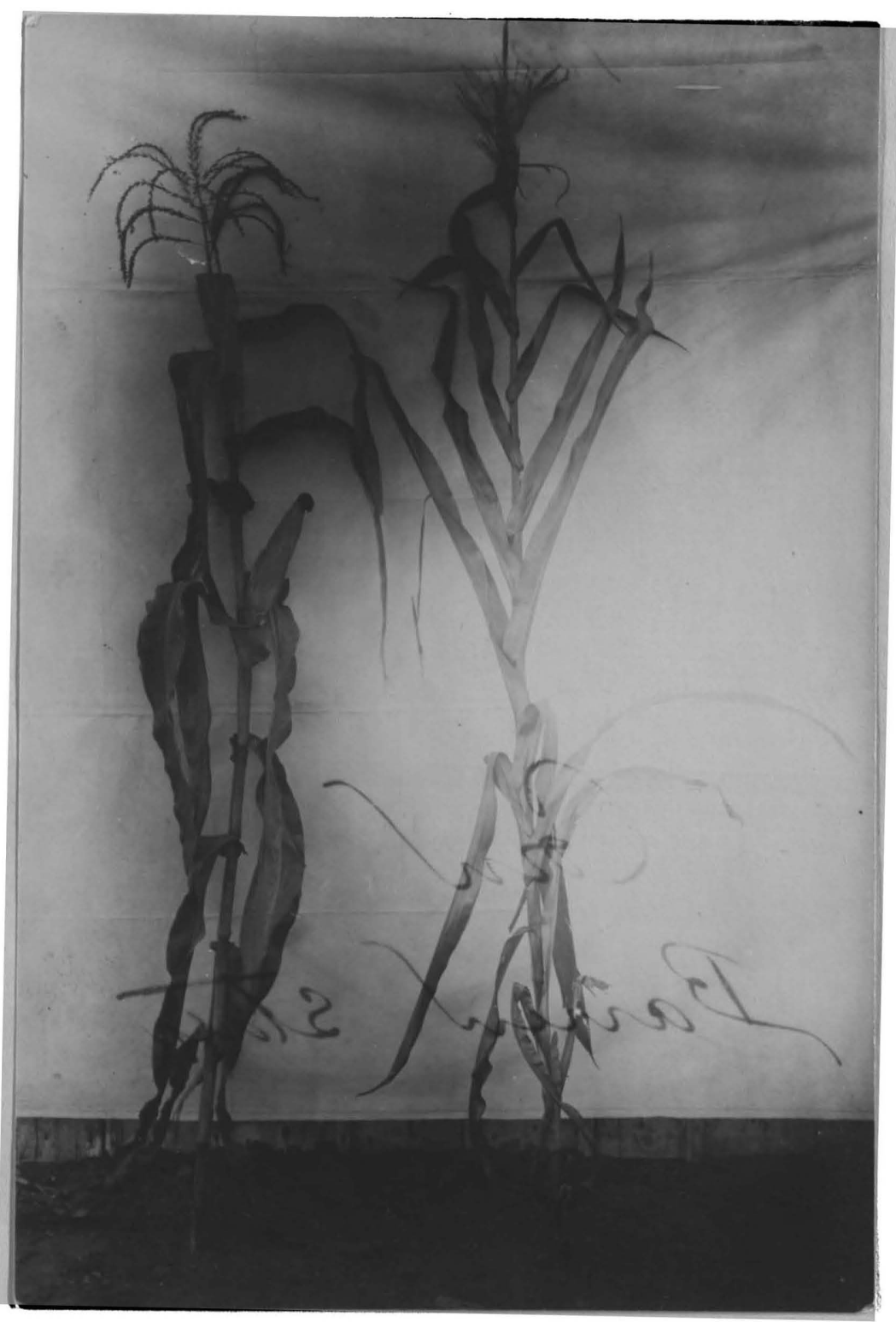







